MAURÍCIO COLETTO DOS SANTOS

\title{
O ESCRITÓRIO DE GERENCIAMENTO DE PROJETOS NO PLANEJAMENTO ESTRATÉGICO E ORÇAMENTÁRIO: UM ESTUDO DE CASO NA INDÚSTRIA DE MÍDIA SOB ENFOQUE DA CIBERNÉTICA.
}

Dissertação apresentada a Escola
Politécnica de São Paulo - USP para
obtenção do título de Mestre em
Engenharia.




\section{O ESCRITÓRIO DE GERENCIAMENTO DE PROJETOS NO PLANEJAMENTO ESTRATÉGICO E ORÇAMENTÁRIO: UM ESTUDO DE CASO NA INDÚSTRIA DE MÍDIA SOB ENFOQUE DA CIBERNÉTICA.}

Dissertação apresentada a Escola
Politécnica de São Paulo - USP para
obtenção do título de Mestre em
Engenharia.

Área de Concentração: Departamento de Engenharia Naval e Oceânica.

Orientador: Prof. Dr. Mardel Bongiovanni de Conti. 
Este exemplar foi revisado e alterado em relação à versão original, sob responsabilidade única do autor e com a anuência de seu orientador.

São Paulo, 28 de Maio de 2007.

Autor:

Maurício Coletto dos Santos

Orientador:

Prof. Dr. Mardel Bongiovanni de Conti

FICHA CATALOGRÁFICA

Santos, Maurício Coletto dos

O escritório de gerenciamento de projetos no planejamento estratégico e orçamentário: um estudo de caso na indústria de mídia sob enfoque da cibernética. / M.C. dos Santos. -- ed. rev. São Paulo, 2007.

$152 \mathrm{p}$.

Dissertação (Mestrado) - Escola Politécnica da Universidade de São Paulo. Departamento de Engenharia Naval e Oceânica.

1.Administração de projetos 2.Administração de portfolios 3.Escritório (Gerenciamento; Projetos) I.Universidade de São Paulo. Escola Politécnica. Departamento de Engenharia Naval e Oceânica II.t. 


\section{DEDICATÓRIA}

A Marcia e Rodrigo, minha esposa e filho amados, que são minhas razões de busca e dedicação no trabalho e na vida acadêmica, desejo expressar meu amor, minha admiração e gratidão pela compreensão, carinho, presença e incansável apoio ao longo do período de elaboração deste trabalho.

Ao meu pai Mário (In memorian) e minha mãe Aparecida, pelo amor e dedicação aos seus filhos, preocupando-se principalmente com a minha educação e formação. 


\section{AGRADECIMENTOS}

Ao Prof. Dr. Mardel Bongiovanni de Conti, meu orientador que, ao longo deste meu período de desenvolvimento acadêmico, além do apoio e orientação no desenvolvimento deste trabalho, me motivou a explorar minhas habilidades e percepções na exposição de pensamento e idéias.

Aos Professores Doutores Bernardo Andrade e Marcelo Ramos pela oportunidade concedida neste programa de mestrado.

Ao Professor Doutor Isaias Custódio que me inspirou, através de suas aulas, nas pesquisas e análises deste trabalho sob o enfoque da Teoria Geral de Sistemas e da Cibernética. 
"Não ignoro que muitos foram e são da opinião que as coisas do mundo são a tal ponto governadas pela sorte e por Deus que os homens, mesmo sábios, não tem o poder de alterá-las, não havendo, pelo contrário, meio algum de corrigi-las, de modo a pensar que não se deva despender muito empenho nas coisas, deixando-as sob o governo da sorte. Esta opinião tem tido muito sucesso atualmente devido às grandes transformações das coisas presenciadas cotidianamente, as quais escapam qualquer previsibilidade humana. Eu mesmo pensando nisso, por vezes, inclinei-me para tal opinião".

"Todavia, para que nosso livre-arbítrio não seja completamente abolido, julgo que possa ser verdade que a sorte seja senhora de metade de nossas ações, mas deixando a nós o governo da outra metade, ou quase"

Nicolau Maquiavel - O Príncipe 


\section{RESUMO}

O presente trabalho realizou um estudo das possibilidades de posicionamento do escritório de gerenciamento de projetos para contextos estratégicos dentro das organizações. A ênfase do estudo encontra-se em avaliar as dificuldades de se implementar estratégias corporativas através de projetos e a forma com a qual um escritório de gerenciamento de projetos pode, de forma prática, contribuir em processos de formação de porta-fólio de projetos dentro dos processos de planejamento estratégico e orçamentário das organizações.

Como estratégia da pesquisa, foi desenvolvida uma revisão da literatura relacionada aos processos de planejamento estratégico e orçamentário, gestão de porta-fólio de projetos e das estruturas especialistas conhecidas na literatura especializada como escritórios de gerenciamento de projetos. Desta revisão estabelece-se um modelo de proposição teórica para a inserção de escritório de gerenciamento de projetos em contextos estratégicos. Em um estudo de caso, o trabalho apresenta a comparação dos principais elementos de referência da teoria com as evidências identificadas na prática. A realidade, neste particular contexto, propiciou a validação da aplicabilidade de alguns instrumentos disponíveis e as dificuldades de aplicação dos mesmos, permitindo confirmar a validade teórica do modelo proposto sob vários aspectos.

Neste trabalho fez-se também 0 uso intensivo de conceitos da Cibernética organizacional e do modelo do VSM (Viable System Model), proposto por Stafford Beer. O VSM foi utilizado principalmente como ferramenta de análise e enquadramento do modelo teórico proposto com as evidências do estudo de caso. Muitos dos aspectos, problemas e relações causais apresentados no estudo de caso puderam ser avaliados de forma prática e demonstraram-se coerentes com a proposta de que os problemas de desempenho verificados nas organizações podem ser analisados sob a perspectiva da violação de algum princípio da Cibernética.

Palavras-chave: Engenharia. Administração de projetos. Administração de portafólio. Escritório (Gerenciamento; Projetos). 


\begin{abstract}
The current work presents a study over the positioning possibilities of project management offices in the organization's strategic environment. The emphasis of this study is on the assessment of the implementations difficulties of the strategies through projects and how a project management office can contribute to reduce these difficulties by supporting project portfolio selection under corporate strategic planning and budgeting processes.
\end{abstract}

As a research strategy, a literature review was developed covering corporate strategic planning and budgeting processes, project portfolio management as well specialist organizational structures known as project management office. From this review, it was built a theory model proposition for project management office insertion on the corporate strategic environment. Through case study analysis, it is submited conclusions obtained from theory review against the identified practical evidences. In this particular research it was possible identify the applicability and difficulties of some available instruments and the proposed theory model was validated under many aspects.

In addition, it was made an intensive use of concepts from the organizational Cybernetics' theory and the viable system model - VSM, proposed by Stafford Beer. The VSM was useful as holistic analysis tool to categorize the proposed theory models against the evidences identified in the case study. Many aspects, problems and causal relationships presented in the case study were assessed in a practical way and proved consistency with the proposal that organizational performance problems could be analyzed under the perspective of some Cybernetic's principies violation.

Key-words: Engineering. Project management. Portfolio management. Office (Management; Project). 


\section{LISTA DE ILUSTRAÇÕES}

Figura 1 - Formação de porta-fólio de projetos dentro do planejamento estratégico e orçamentário.

Figura 2 - Modelo de Retroalimentação Negativa

33

Figura 3 - O Modelo de Sistema Viável.

Figura 4 - Planejamento estratégico - Fase I.

Figura 5 - Planejamento estratégico - Fase II.

Figura 6 - Planejamento estratégico - Fase III.

Figura 7 - Planejamento estratégico - Fase IV.

Figura 8 - Planejamento estratégico - Componente orçamentário.

Figura 9 - Planejamento estratégico - processo de geração de propostas de projetos.

Figura 10 - Mortalidade de propostas para novos produtos / projetos.

Figura 11 - Investimentos acumulados ao longo do tempo.

Figura 12 - Planejamento estratégico - processos de seleção de projetos. 70

Figura 13 - A localização de um EGP dentro da hierarquia organizacional.

Figura 14 - O escopo do trabalho do Escritório de Projetos em Estágios..

Figura 15 - EGP atuando como apoio no planejamento estratégico e orçamentário.

Figura 16 - Desempenho de investimentos em publicidade e circulação de jornais no Brasil.

Figura 17 - Visão VSM para a configuração do grupo empresarial antes da reestruturação. 
Figura 18 - Visão VSM indicando a reestruturação do grupo

Figura 19 - Elementos de orientação do processo orçamentário. 106

Figura 20 - Planilha de priorização de projetos do processo orçamentário.

Figura 21- Fluxo do processo orçamentário de investimentos.

Figura 22 - Visão VSM indicando o âmbito de atuação da área corporativa de planejamento do CSC.

Figura 23 - Visão VSM indicando a atuação do comitê executivo do grupo na definição de um porta-fólio de projetos.

Figura 24 - Visão VSM indicando a atuação da nova área corporativa de IT.

Figura 25 - Visão VSM para um meta-sistema projeto

Figura 26 - Organograma do EGP implementado pela área de IT 124

Figura 27 - Fases de um projeto na metodologia de gestão de projetos desenvolvida pela área de informação e tecnologia.

Figura 28- Visão VSM para o EGP.

Figura 29 - O Processo de gestão de demandas.

Figura 30 - O filtro de demandas de projetos.

Figura 31 - Expansão da metodologia de gestão de projetos.

Figura 32 - Fluxo do processo de orçamento de investimentos revisado Parte I.

Figura 33 - Fluxo do processo de orçamento de investimentos revisado Parte II.

Figura 34 - Fluxo do processo de orçamento de investimentos revisado Parte III.

Figura 35 - Visão VSM para o processo de orçamento corporativo do grupo após a revisão, para o componente de investimentos em projetos.. 


\section{LISTA DE TABELAS}

Tabela 1 - Resumo da Bibliografia: Cibernética e o modelo de sistema viável.. $\quad 24$

Tabela 2 - Resumo da Bibliografia: Planejamento estratégico e orçamentário.. 25

Tabela 3 - Resumo da Bibliografia: Gestão de porta-fólio de projetos................ 25

Tabela 4 - Resumo da Bibliografia: Escritórios de gerenciamento de projetos.. 26

Tabela 5 - Exemplo de planilha de pontuação para avaliação de propostas de

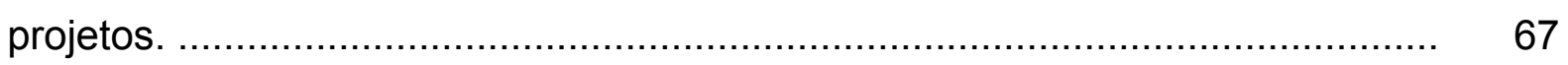

Tabela 6 - Planilha de priorização de demandas. ........................................... 133 


\section{LISTA DE SIGLAS e TERMOS}

CSC - Centro de Serviços Compartilhados.

EGP - Escritório de Gerenciamento de Projetos.

PMI - Project Management Institute.

PMBOK - Project Management Body of Knowledge.

SWOT - Strengths, Weakness, Opportunities and Threats.

TGS - Teoria Geral de Sistemas.

VSM - Viable System Model. 


\section{SUMÁRIO}

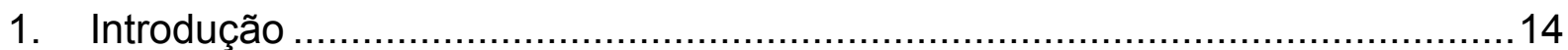

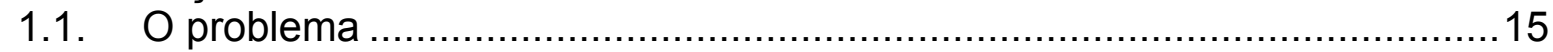

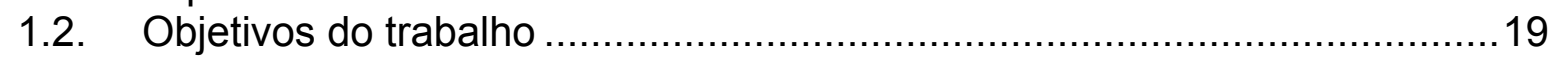

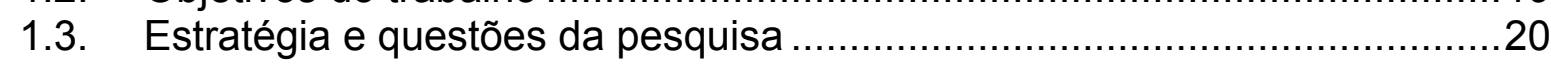

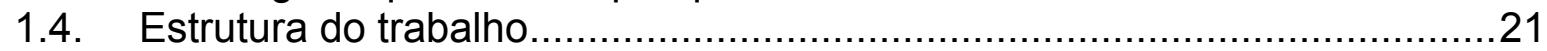

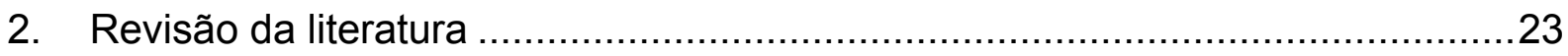

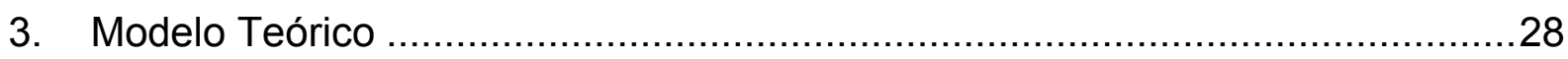

3.1. Cibernética organizacional e o modelo de sistema viável ........................28

3.2. Planejamento estratégico e orçamentário .............................................44

3.3. Gestão de porta-fólio de projetos .......................................................57

3.4. Escritórios de gerenciamento de projetos ........................................ 72

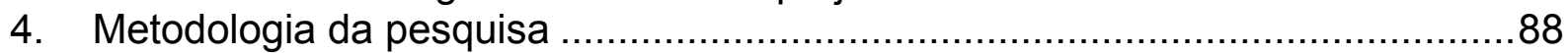

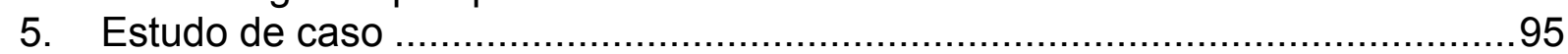

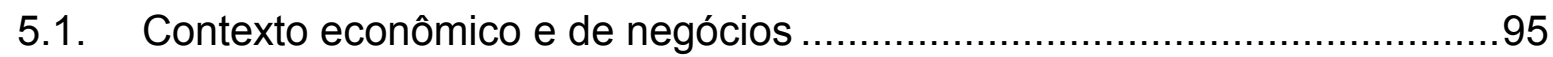

5.2. Estrutura e organização do estudo de caso ....................................... 97

5.3. Histórico e a reestruturação do grupo ...............................................99

5.4. O Planejamento estratégico e orçamentário .....................................103

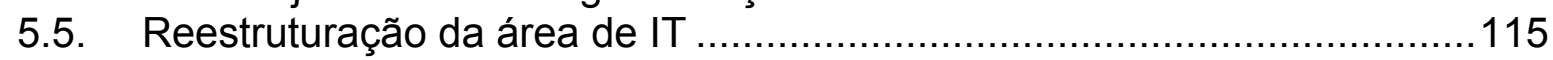

5.8. Revisão do processo orçamentário .................................................... 137

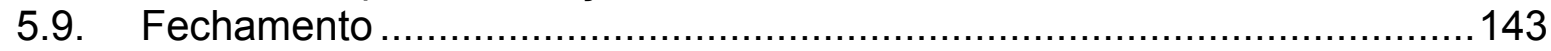

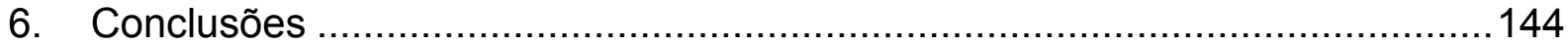

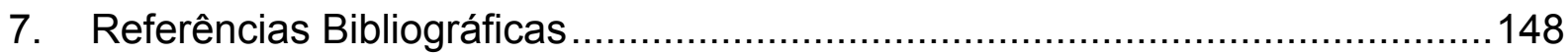




\section{Introdução}

Após a segunda guerra mundial, as nações industrializadas passaram por uma revolução na engenharia de produtos nunca antes vista. As pesquisas e descobertas da ciência proporcionadas pelo intenso avanço das tecnologias militares até a década de 1940 passaram a ser a matéria prima em um processo de inovação de produtos que mobilizou indústrias de processos em todo o mundo. Com a inovação veio também a obsolescência que demandou das organizações intensos investimentos na busca de mais inovação, porém em velocidades que até então a moderna administração não tinha tido contato (HOBSBAWN, 1995).

Este novo paradigma impôs às organizações a necessidade de, cada vez mais, empenhar grandes investimentos em pesquisa e desenvolvimento, bem como em projetos $^{1}$ de caráter estratégico e de grande complexidade. A necessidade de implementar projetos passa a ser crucial para as corporações na manutenção das suas posições dentro dos mercados. Diante de um cenário intenso, dinâmico e de constante busca, as organizações começaram a se dar conta do volume de perdas em tentativas frustradas de buscar a competitividade através de projetos. Este processo permeia a dinâmica dos mercados até os dias de hoje e transcende não só as necessidades de novos produtos, mas também serviços, processos e a forma com a qual as empresas se organizam e adaptam seus negócios.

Embora as ferramentas e as formas de determinar a melhor alocação de capital de investimentos tenham mudado ao longo do tempo, a necessidade básica continua a mesma: empresas devem alocar um conjunto limitado de recursos em projetos, de forma a balancear riscos e retorno, garantindo alinhamento com a estratégia corporativa (KERZNER, 2004). Ainda que uma variedade de ferramentas e métodos analíticos possa ser utilizada na seleção de projetos, processos precisam estar presentes para que as pessoas envolvidas na tomada de decisão possam compartilhar de uma visão comum em um método estruturado por etapas bem definidas (RASMUSSEN et al., 2003).

\footnotetext{
${ }^{1}$ Projeto é definido aqui como um empreendimento temporário com objetivos de criar um produto, serviço ou resultado de caráter único (PMI, 2004).
} 
Sob este panorama, ciências como as de administração e finanças passaram as últimas décadas preocupando-se em desenvolver meios eficientes de definir estratégias e processos decisórios, principalmente para determinação de investimentos estratégicos. Desta busca, os modelos de planejamento corporativos evoluíram desde os anos 1950 até tomarem a forma a qual conhecemos hoje. Processos como de planejamento estratégico e orçamentário são um dos resultados desta evolução e buscam direcionar os recursos financeiros disponíveis na organização para as suas operações e para os investimentos na forma de projetos.

Muito embora os modelos adotados de planejamento das organizações variem de acordo com a abordagem das suas direções, bem como o tipo de negócio e cultura da empresa, o processo convencional consiste em estabelecer um padrão de comportamento para toda a empresa na forma de metas ou objetivos estratégicos que devem ser transformados em um programa de ações. Em geral, a área financeira das empresas, sob orientação da alta direção, publica e difunde as estratégias e metas de negócio a serem perseguidas para as diversas áreas e ou unidades de negócio que compõem uma organização. Estas são então orientadas a formularem seus planos de ações, manifestados em orçamentos que em parte são compostos de investimentos na forma de projetos (MINTZBERG; BRUCE, 2000; LORANGE; VANCIL, 1977; LUNKES, 2003). A aprovação dos orçamentos, consequentemente define também uma carteira de projetos corporativos.

\subsection{O problema}

Na prática, o que se tem observado é que o ferramental matemático e analítico para a tomada de decisão evoluiu de uma forma muito mais intensa do que os meios e processos pelo qual o modelo possa ser colocado em prática dentro das várias hierarquias e diversidades presentes em uma organização.

As organizações humanas são estruturas complexas, compostas por subsistemas autônomos onde predominam as interpretações de indivíduos que também fazem parte deste sistema. Essas características dos sistemas organizacionais estabelecem um padrão de comportamento que foge ao controle dos executivos, 
produzindo resultados inesperados em processos que supostamente deveriam estabelecer um padrão adequado de respostas. Os processos de planejamento estratégico e orçamentário não escapam desta realidade e são um bom exemplo das dificuldades enfrentadas pela alta direção das empresas no desenvolvimento de planos de ações que devem ser conciliados pelas diversas visões que compõem um sistema organizacional.

O problema acentua-se quando a esses planos se incluem variáveis relacionadas à correta composição de um porta-fólio de projetos corporativos. As diferentes percepções dos indivíduos perante uma estratégia e prioridades, bem como as dificuldades de comunicação entre os diversos níveis hierárquicos e disciplinas envolvidas em uma organização, estabelecem um cenário de alto risco na definição de uma carteira de projetos a serem aprovados.

A questão orçamentária é um assunto amplamente discutido e sua relevância é notável por se tratar de um processo fundamental na implementação de uma estratégia corporativa e do fato que as organizações, em sua maioria, o vêem como um momento conturbado e extenuante dentro da dinâmica das outras atividades do dia-a-dia (MOORE, 1999; LORANGE; VANCIL, 1977). O que se verifica com muita freqüência é o desconhecimento da importância do processo e a falta de orientação na execução do mesmo. As diversas áreas e unidades de negócio o conduzem de forma isolada e sem, ou quase, nenhuma ajuda ou orientação.

Nem sempre as partes envolvidas entendem uma estratégia definida ou ainda são capazes de encaminhá-las na forma de projetos. As demandas do dia-a-dia e as pressões por resultados também contribuem negativamente e fazem com que os gestores não tenham disponibilidade de tempo para efetuar uma revisão interna que provavelmente descartaria várias propostas, demonstrando prazos e custos infundados (KERZNER 2004). Em outras situações e não raramente, componentes políticas ou ainda pessoais interferem no julgamento dos gestores, que muitas vezes defendem projetos inviáveis ou ainda desalinhados com uma estratégia proposta.

De fato, um estudo desenvolvido pela consultoria Accenture em associação com a Universidade de Cranfield (NEELY; SUTCLIFF; HEYNS, 2001) aponta que $80 \%$ das 
companhias que praticam processos de planejamento estratégico e orçamentário se declaram insatisfeitas com os resultados obtidos. O trabalho da consultoria aponta significantes falhas nos modelos praticados pelas companhias. Cabe aqui o realce de algumas das principais críticas levantadas quanto à abordagem praticada:

- Consome um longo tempo e é custosa;

- Raramente está orientada à estratégia corporativa e, freqüentemente apresenta contradições;

- Concentra-se na redução de custos e não na adição de valor;

- Reforça a criação de barreiras departamentais ao invés de encorajar o compartilhamento de conhecimentos e informações.

Neste mesmo trabalho, a consultoria aponta um levantamento efetuado junto a diretores financeiros em 40 companhias que indica que a grande maioria deles coloca como uma de suas principais prioridades a necessidade de uma reforma no processo orçamentário. Isto decorre da preocupação dos executivos com a qualidade e os resultados das propostas orçamentárias desenvolvidas, na medida em que os investimentos se tornam cada vez mais complexos e com grandes aportes financeiros.

Por outro lado, face aos grandes desafios de se gerenciar os investimentos estratégicos das organizações, estamos observando uma grande revolução nas práticas de gerência de projetos nas últimas décadas. Com o atual panorama das dinâmicas de mercados, a competitividade e complexidade dos empreendimentos, diversos autores consideram que a forma mais adequada para se gerenciar investimentos é a administração por projetos (KERZNER, 2001 (a), 2004; CLELAND, 1999; LUNKES, 2003). De fato, esta disciplina vem crescendo e ganhando corpo, pois a necessidade e as exigências do mercado demandam cada vez mais a introdução de projetos como meio de explorar estratégias competitivas.

A evolução dos conceitos da administração de projetos vive, portanto, um momento de progresso visível em direção ao profissionalismo e ao uso de métodos e técnicas de gerenciamento cada vez mais apuradas. Com o crescimento e com a disseminação da disciplina nos mais diversos segmentos do mercado, começaram a 
surgir também estruturas organizacionais responsáveis pela garantia dos processos de gerência de projetos dentro das organizações (BARCAUI; QUELHAS, 2004).

Os EGPs - Escritório de Gerenciamento de Projetos - vêm sendo sistematicamente implementados nas organizações e este fenômeno tornou-se tão popular que muito da literatura recente sobre o assunto considera o EGP como a resposta para vários dos problemas que preocupam as organizações no que diz respeito à capacitação de seus recursos humanos na gestão profissional de projetos. Porém, muito pouco tem sido explorado das competências de um EGP como elemento de apoio nos processos de planejamento estratégico e o restante da organização. Uma argumentação para esta deficiência seria o fato de que os EGPs, em geral, nascem de necessidades específicas de departamentos, e evoluem longe do conhecimento da alta direção das organizações (KENDALL; ROLLINS, 2003).

Tucker e Agopian reforçam esta hipótese pela observação de iniciativas de áreas como a de Informação e Tecnologia. Pela própria característica de riscos e históricos de projetos que envolvem tecnologia de informação, esta área tem sido uma das principais demandantes de práticas em gestão de projetos e da criação de EGPs. Estes autores defendem que estruturas como o EGP nascem para atender demandas no nível operacional da gestão de projetos e, conforme seu valor é reconhecido pelo resto da organização, evoluem e passam a assumir competências em um nível estratégico (TUCKER; AGOPIAN, 2006) .

Enquanto atuam em um escopo operacional, os EGPs possuem características funcionais orientadas ao planejamento, execução e entrega de projetos. Em um nível estratégico, o EGP passa a ter competências orientadas a definição de portafólio de projetos corporativos, otimização e balanceamento de investimentos e adaptação do ambiente de negócio (KERZNER, 2004; TUCKER; AGOPIAN, 2006; KENDALL; ROLLINS, 2003; DINSMORE; GRAHAM; ENGLUND, 2003).

Como síntese da estruturação de um problema, cabe aqui duas observações importantes a serem destacadas neste preâmbulo: 
- Os cenários apresentados, decorrentes das dificuldades no desenvolvimento do planejamento estratégico e orçamentário, seguidos pelas necessidades de formação e gestão de porta-fólio de projetos corporativos, representam um dos grandes problemas para a administração estratégica nos dias de hoje.

- Os EGPs oferecem um conjunto de competências e especialidades que podem ajudar a reduzir essas dificuldades e distorções dentro de modelos decisórios de planejamento estratégico e orçamentário das corporações, mais precisamente no que diz respeito ao componente de investimentos em projetos.

\subsection{Objetivos do trabalho}

Através de um estudo de caso, este trabalho apresenta a evolução de um EGP, que nasce de uma iniciativa isolada em uma área corporativa com funções predominantemente funcionais e evoluiu para assumir papéis que o aproximaram de um contexto de cunho estratégico, apoiando processos como o de orçamento corporativo na formação de um porta-fólio de projetos.

A evidência prática proporcionada pelo estudo de caso apresenta-se como uma possibilidade diante dos problemas de interesse nesta pesquisa científica. Como síntese de uma proposta com caráter de uma pesquisa aplicada, o trabalho possui os seguintes objetivos:

- Apresentar o processo de evolução de um EGP para contextos mais estratégicos dentro de uma organização;

- Demonstrar que este processo de evolução decorre naturalmente da necessidade de manutenção da viabilidade de uma organização;

- Compor um modelo teórico, com base em modelos consagrados na literatura, que instrumentalize a proposta desta pesquisa;

- Verificar a previsibilidade deste modelo diante do estudo de caso apresentado; 
- Disseminar os conhecimentos relativos a esse modelo e às evidências do estudo de caso nas práticas organizacionais de gestão estratégica de porta-fólio de projetos corporativos.

\subsection{Estratégia e questões da pesquisa}

Como uma pesquisa de caráter empírico e qualitativo, o presente trabalho apóia-se nos seguintes elementos:

- Pesquisa bibliográfica - Tem como objetivo evidenciar, nos diversos assuntos envolvidos, uma cadeia lógica de relações, causas e efeitos que propiciam uma visão do problema investigado sob um enfoque sistêmico. As seguintes disciplinas e assuntos são explorados:

- Processos de formulação e implementação de estratégias corporativas através da aplicação de planejamento estratégico e orçamentário;

- Seleção e gestão de porta-fólio de projetos corporativos;

- Escritório de gerenciamento de projetos.

- Estudo de caso - Serve como elemento de demonstração que o roteiro teórico apresenta as relações identificadas e que a proposição de solução é válida na medida esperada pelo método científico da indução.

O trabalho pretende responder a seguinte questão:

- Quais as condições para que um de escritórios de gerenciamento de projetos evolua para níveis corporativos mais estratégicos?

Como pano de fundo, na interpretação de modelos de comunicação e controle das organizações, o trabalho explora o modelo de sistema viável proposto por Beer (BEER, 1979), com objetivos de investigar o estudo de caso face as possíveis 
relações entre desempenho dos subsistemas corporativos na operacionalização das estratégias e do uso de estruturas como o EGP.

Com os trabalhos desenvolvidos por Stafford Beer em sua obra "Organizational Cybernetics", os conceitos de sistemas foram estendidos para a visão organizacional, com objetivos de romper-se com o modelo tradicional de padrão de pensamento na administração. Beer produz o que ele denominou de modelo de sistema viável (Viable System Model - VSM ), que corresponde ao conjunto chave de funcionalidades que um sistema corporativo deve apresentar para que se garanta a sobrevivência e integridade do mesmo (BEER, 1979).

Devido o caráter orgânico, que se deseja impor na avaliação dos processos e problemas que este estudo se propõe, neste trabalho, existe o predomínio da visão da empresa como um sistema e o enquadramento das evidências e hipóteses estabelecidas pela teoria, serão feitos com apoio de conceitos da Cibernética e do modelo de sistema viável.

\subsection{Estrutura do trabalho}

Diante da variedade de assuntos e temas que permeiam este trabalho, fez-se necessária uma estruturação de tópicos orientada aos diversos conceitos identificados no problema em estudo e o trabalho encontra-se estruturado da seguinte forma:

Capítulo I - Introdução;

Capítulo II - Revisão da literatura;

Capítulo III - Modelo Teórico:

- Cibernética organizacional e o modelo de sistema viável;

- Planejamento estratégico e orçamentário;

- Gestão de porta-fólio de projetos;

- Escritórios de gerenciamento de projetos.

Capítulo IV - Metodologia de pesquisa;

Capítulo V - Estudo de caso; 
Capítulo VI - Conclusões;

Capítulo VII - Referências bibliográficas. 


\section{Revisão da literatura}

Existe uma questão central que permeia uma das principais preocupações das administrações contemporâneas: Como alocar os recursos limitados de uma organização em proposições viáveis de projetos, garantindo alinhamento com uma estratégia corporativa?

Segundo Porter, uma empresa pode ser vista como um conjunto de tecnologias e estas estão contidas não apenas em equipamentos, produtos e pesquisa e desenvolvimento, mas também em atividades primárias de produção e vendas, bem como em atividades de apoio, tais como as administrativas. As tecnologias de uma empresa são resultados de um processo de evolução, amadurecimento e principalmente de investimentos em projetos que afetam na vantagem competitiva se a aplicação das mesmas tiver um papel significativo na determinação da posição por uma liderança por custos ou diferenciação (PORTER, 1990).

De fato, existem três principais razões para as organizações empreender projetos (KERZNER, 2004):

1. Para produzir novos produtos ou serviços para sustentar um crescimento lucrativo;

2. Para introduzir melhorias e ou funcionalidades em processos internos, produtos ou serviços existentes, promovendo uma redução de custos ou melhoria na qualidade;

3. Para produzir conhecimento científico que suporte a identificação de novas oportunidades.

Neste trabalho, avaliam-se ganhos pela incorporação de atribuições de estruturas conhecidas na literatura especializada como escritórios de gerenciamento de projetos nas atividades de planejamento estratégico e orçamentário das organizações, atuando principalmente como elemento de coordenação e apoio nos processos de formação de porta-fólio de projetos. 
Para a construção de um modelo teórico que apóie esta proposta, uma revisão bibliográfica, orientada aos diversos conceitos identificados no problema em estudo, foi efetuada e as tabelas abaixo apresentam um resumo dos principais assuntos e as referências bibliográficas pesquisadas.

\begin{tabular}{|c|c|}
\hline \multicolumn{2}{|c|}{ Cibernética e o modelo de sistema viável } \\
\hline Resumo & Principais Bibliografias \\
\hline $\begin{array}{l}\text { Como contraponto à abordagem mecanicista e } \\
\text { reducionista da visão Newtoniana e da necessidade } \\
\text { de encontrar-se modelos que viabilizem o estudo do } \\
\text { comportamento de sistemas biológicos e sociais, } \\
\text { novas teorias e ciências surgem em meados do } \\
\text { século XX, estabelecendo propostas orientadas por } \\
\text { uma visão sistêmica em ambientes de alta } \\
\text { complexidade. (Teoria da Complexidade, Teoria } \\
\text { Geral de Sistemas e Cibernética). A proposta de } \\
\text { estabelecer mecanismos de auto-regulação, } \\
\text { conceitos de técnicas como da "caixa preta" e a } \\
\text { abordagem para tratamento de estruturas } \\
\text { complexas, dissipativas e não-lineares permitiram o } \\
\text { desenvolvimento de modelos mais adequados e } \\
\text { práticos na modelagem de sistemas. (WIENER, } \\
\text { 1948; BERTALANFFY, 1975; ASHBY, 1957; BEER, } \\
\text { 1969; FORRESTER; 1999(a)). } \\
\text { Com os trabalhos desenvolvidos por Stafford Beer } \\
\text { em sua obra "Organizational Cybernetics", os } \\
\text { conceitos de sistemas foram estendidos para a visão } \\
\text { organizacional, com objetivos de romper-se com o } \\
\text { modelo tradicional de padrão de pensamento na } \\
\text { administração. Beer produz o que ele denominou de } \\
\text { Modelo de Sistema Viável (Viable System Model - } \\
\text { VSM ), que corresponde ao conjunto chave de } \\
\text { funcionalidades que qualquer sistema viável deve } \\
\text { apresentar (BEER, 1979). } \\
\text { Autores, como Flood e Jackson, enfatizam a } \\
\text { necessidade da visão sistêmica no desenho e } \\
\text { análise de organizações corporativas e apresentam } \\
\text { as várias formas de pensamento que derivaram da } \\
\text { Teoria Geral de Sistemas. Os autores sugerem o uso } \\
\text { de metáforas sistêmicas ou abordagens específicas } \\
\text { para estabelecer modelos práticos de aplicação em } \\
\text { áreas como a da Administração (FLOOD, 2002; } \\
\text { JACKSON, 2003). } \\
\text { Embora vários artigos e trabalhos de origem nacional } \\
\text { tenham sido identificados, verificou-se também que, } \\
\text { muito do uso prático do VSM em ambientes } \\
\text { corporativos encontra-se em artigos de autoria } \\
\text { estrangeira. Curiosamente, identificou-se um } \\
\text { trabalho estrangeiro (SCHWANINGER, 2006) onde o } \\
\text { autor apresenta o uso do VSM como ferramenta de } \\
\text { análise e diagnóstico em um estudo de caso que } \\
\text { envolveu uma empresa nacional também do ramo de } \\
\text { mídia. }\end{array}$ & $\begin{array}{l}\text { ASHBY, W. R. An introduction to cybernetics. London: } \\
\text { Chapman \& Hall LTD, 1957. } \\
\text { BEER, S. Cibernética e administração industrial. Rio de } \\
\text { Janeiro: Zahar, 1969. } \\
\text {. The heart of enterprise. New York: Willey, } \\
\text { 1979.BERTALANFF, Ludwig von. Teoria Geral dos } \\
\text { Sistemas. Rio de Janeiro: Vozes, } 1975 \text {. } \\
\text { FLOOD, Robert L. Creative problem solving: total } \\
\text { system intervention. New York: John Wiley \& Sons, } \\
\text { 2002. } \\
\text { FORRESTER, J. W. Industrial dynamics. EUA: Pegasus } \\
\text { Com., 1999 (a). } \\
\text { Pegasus Com., } 1999 \text { (b). } \\
\text { JACKSON, M. C. System thinking: creative holism for } \\
\text { Managers. University of Hull, UK. New York: John Wiley } \\
\text { \& Sons, 2003. } \\
\text { MATURANA, H.; VARELA, F. Árvore do conhecimento: } \\
\text { as bases biológicas da compreensão humana. São } \\
\text { Paulo: Palas athena, 2001. } \\
\text { ROBERTS, N.; et al. Introduction to computer } \\
\text { simulation: the system dynamics approach. USA: Lesley } \\
\text { College, 1983. } \\
\text { SCHWANINGER, M. Design for viable organizations: } \\
\text { the diagnostic power of the viable system model, } \\
\text { Switzerland Kybernetes, University of St Gallen, St } \\
\text { Gallen v. } 35, n \text {. } 7 / 8, p \text {. 955-966, 2006. } \\
\text { WIENER, N. Cybernetics or control and communication } \\
\text { in the animal and machine. New York: John Wiley, 1948. }\end{array}$ \\
\hline
\end{tabular}

Tabela 1 - Resumo da Bibliografia: Cibernética e o modelo de sistema viável. 


\begin{tabular}{|c|c|}
\hline \multicolumn{2}{|c|}{ Planejamento estratégico e orçamentário } \\
\hline Resumo & Principais Bibliografias \\
\hline $\begin{array}{l}\text { O histórico dos modelos atuais de planejamento e as } \\
\text { várias formas de se planejar e estabelecer } \\
\text { estratégias corporativas são exploradas por diversos } \\
\text { autores, indicando uma evolução destes conceitos e } \\
\text { processos, principalmente após a Segunda Guerra } \\
\text { Mundial (ANTHONY, 1970; TAVARES, 2000; } \\
\text { MINTZBERG; BRUCE, 2000). }\end{array}$ & $\begin{array}{l}\text { ANTHONY, R. N. Contabilidade gerencial: introdução à } \\
\text { contabilidade. São Paulo: Atlas, } 1970 \text {. } \\
\text { KOYAMA, H. H; TASSEL, R. V. How to trim Capital } \\
\text { Spending by } 25 \text { percent. The McKinsey Quarterly, n.3, } \\
1998 . \\
\text { LERE, J. C. Managerial accounting: a planning-operating- } \\
\text { control framework. New Jersey: John Wiley \& Sons, } \\
\text { 1991. }\end{array}$ \\
\hline $\begin{array}{l}\text { Mintzberg apresenta as várias escolas de } \\
\text { planejamento que derivaram desta evolução e } \\
\text { propõe críticas e pontos fortes em cada uma das } \\
\text { abordagens (MINTZBERG; BRUCE, 2000). }\end{array}$ & $\begin{array}{l}\text { LORANGE, P.; VANCIL, R. F. Strategic planning } \\
\text { systems. USA: Prentice-Hall Inc., } 1977 . \\
\begin{array}{l}\text { Inc., } 1980 . \quad \text {. Corporate planning. USA: Prentice-Hall } \\
\text { Implementation of strategic planning. }\end{array}\end{array}$ \\
\hline $\begin{array}{l}\text { Modelos de aplicação de planejamento estratégico } \\
\text { também são apresentados para diversas visões, } \\
\text { contextos e tamanhos de corporações (LORANGE; } \\
\text { VANCIL, 1977; LORANGE, 1980, 1982; } \\
\text { MINTZBERG; QUINN, 2001; PORTER, 1990). }\end{array}$ & $\begin{array}{l}\text { USA: Prentice-Hall Inc., } 1982 . \\
\text { LUNKES, R. J. Manual de orçamento. São Paulo: Atlas, } \\
2003 . \\
\text { MINTZBERG, H.; BRUCE, A. Safári de estratégia: um } \\
\text { roteiro pela selva do planejamento estratégico. Porto } \\
\text { Alegre: Bookman, 2000. }\end{array}$ \\
\hline $\begin{array}{l}\text { Vários autores também apresentam as dificuldades } \\
\text { inerentes do processo de desenvolvimento e }\end{array}$ & $\begin{array}{l}\text { MINTZBERG, H. ; QUINN, J. B. O processo da } \\
\text { estratégia. Porto Alegre: Bookman, } 2001 .\end{array}$ \\
\hline $\begin{array}{l}\text { implementação de estratégias corporativas dentro de } \\
\text { ambientes organizacionais e apontam que grande } \\
\text { parte das dificuldades estabelece-se pelas diferentes }\end{array}$ & $\begin{array}{l}\text { NEELY, A.; SUTCLIFF, M. R; HEYNS, H. R. Driving } \\
\text { value through strategic planning and budgeting. } \\
\text { Accenture in Association with Cranfield University, } 2001 .\end{array}$ \\
\hline $\begin{array}{l}\text { visões e modelos de comunicação que permeiam as } \\
\text { diversas hierarquias (LORANGE, 1980; NEELY; } \\
\text { SUTCLIFF; HEYNS, 2001; MOORE, 1999; } \\
\text { RASMUSSEN et al.,2003). }\end{array}$ & $\begin{array}{l}\text { PORTER, M. E. Vantagem competitiva: criando e } \\
\text { Sustentando um Desempenho Superior. Rio de Janeiro: } \\
\text { Campus, } 1990 . \\
\text { RASMUSSEN, N. H. et al. Process Improvement for } \\
\text { Effective Budgeting and Financial Reporting. New York: }\end{array}$ \\
\hline $\begin{array}{l}\text { Várias obras consultadas são de abordagem prática } \\
\text { e didática na aplicação de planejamentos } \\
\text { orçamentários corporativos e estabelecem a } \\
\text { importância deste componente dentro do } \\
\text { planejamento estratégico das organizações. Autores } \\
\text { como Rasmussen sugerem metodologias e } \\
\text { processos para a condução de orçamentos } \\
\text { corporativo na forma de um projeto.(RASMUSSEN et } \\
\text { al., 2003; LUNKES, 2003; SANVICENTE ; SANTOS, } \\
\text { 2000; REBOUÇAS, 1997). }\end{array}$ & $\begin{array}{l}\text { John Wiley \& Sons, } 2003 . \\
\text { REBOUÇAS, O. P. D. Planejamento estratégico: } \\
\text { conceitos, metodologias e práticas. São Paulo: Atlas } \\
1997 . \\
\text { SANVICENTE, A Z.; SANTOS, C. da C. Orçamento na } \\
\text { administração de empresas: planejamento e controle. } \\
\text { São Paulo: Atlas, 2000. } \\
\text { TAVARES, M. C. Gestão estratégica. São Paulo: Atlas, } \\
\text { 2000. }\end{array}$ \\
\hline $\begin{array}{l}\text { Autores também fazem referências à importância do } \\
\text { componente de investimentos e da necessidade de } \\
\text { se implementar estratégias corporativas através de } \\
\text { modelos profissionais de gestão de projetos } \\
\text { (KOYAMA; TASSEL, 1998; LUNKES, 2003; NEELY; } \\
\text { SUTCLIFF; HEYNS, 2001) }\end{array}$ & \\
\hline
\end{tabular}

Tabela 2 - Resumo da Bibliografia: Planejamento estratégico e orçamentário.

\section{Gestão de porta-fólio de projetos}

\begin{tabular}{|c|c|}
\hline Resumo & Principais Bibliografias \\
\hline $\begin{array}{l}\text { Os autores apresentam, de forma geral, a } \\
\text { importância das práticas de gestão profissional de }\end{array}$ & $\begin{array}{l}\text { CLELAN } \\
\text { and impl }\end{array}$ \\
\hline $\begin{array}{l}\text { projetos e o vínculo existente entre a implementação } \\
\text { de uma estratégica corporativa e a necessidade de }\end{array}$ & $\begin{array}{l}\text { CRAWFORD, J. K. The strategic project office: a guide } \\
\text { to improving organizational performance. USA: CRC } \\
\text { Press, 2002. }\end{array}$ \\
\hline Processos, métodos, técnicas e ferramentas de & $\begin{array}{l}\text { DICKINSON, M. W; THORNTON, A. C.;GRAVES, S. } \\
\text { Technology Portfolio Management: Optimizing }\end{array}$ \\
\hline
\end{tabular}


priorização e seleção de projetos são apresentados em diversas obras (CRAWFORD, 2000; KERZNER, 2001(a),(b), 2004; CLELAND, 1999; KOYAMA; TASSEL, 1998; MEREDITH; MANTEL, 2000 ).

Autores como Kendall e Rollins apresentam modelos práticos e estruturados de gestão de porta-fólio através da aplicação de escritórios de gerenciamento de projetos. (KENDALL; ROLLINS, 2003).

Dickinson apresenta um valioso modelo de práticas e soluções adotadas para gestão de porta-fólio em situações específicas onde existe a necessidade de se considerar dependências entre projetos de tecnologia e inovação (DICKINSON; THORNTON; GRAVES, 2001).
Interdependent Projects Over Multiple Time Periods. IEEE - Transactions on engineering management, v. 48, n. 4, p. 518-527, 2001.

KENDALL, G.; ROLLINS, S. Advanced project portfolio management and the PMO: multiplying $\mathrm{ROI}$ at warp speed. Boca Raton: J.Ross Publising Inc., 2003.

KOYAMA, H. H; TASSEL, R. V. How to trim Capital Spending by 25 percent. The McKinsey Quarterly, n.3, 1998.

KERZNER, H. Project management: a system approach to planning, scheduling and controlling. New York: John Wiley \& Sons, 2001 (a).

KERZNER, H. Strategic planning for project management using a project management maturity model. New York: John Wiley \& Sons, 2001 (b).

Advanced project management: Best practices on implementation. New York: John Wiley \& Sons, 2004

MEREDITH, J. R; MANTEL, S. J. Project management : a managerial approach. New York: Wiley \& Sons, 2000.

Tabela 3 - Resumo da Bibliografia: Gestão de porta-fólio de projetos.

\begin{tabular}{|c|c|}
\hline \multicolumn{2}{|c|}{ Escritórios de gerenciamento de projetos } \\
\hline Resumo & Principais Bibliografias \\
\hline $\begin{array}{l}\text { O histórico da introdução de modelos de escritórios } \\
\text { de gerenciamento de projeto, bem como os } \\
\text { diferentes modelos e tipos são apresentados e } \\
\text { qualificados por diversos autores (CRAWFORD, } \\
\text { 2000; KERZNER, 2004; FRAME; BLOCK, 1998; } \\
\text { RAD; LEVIN, 2002; TUCKER; AGOPIAN, 2006; } \\
\text { DINSMORE; GRAHAM; ENGLUND, 2003). } \\
\text { Várias obras estão orientadas à implementação e } \\
\text { aplicação prática de escritório de projetos e oferecem } \\
\text { uma valiosa referência neste assunto (KENDALL; } \\
\text { ROLLINS, 2003; CRAWFORD, 2000; KERZNER, } \\
2001 \text { (b); RAD; LEVIN, 2002; DINSMORE; GRAHAM; } \\
\text { ENGLUND, 2003). } \\
\text { As obras também estabelecem ênfase em promover } \\
\text { o perfil do escritório de gerenciamento de projetos } \\
\text { para contextos mais estratégicos dentro das } \\
\text { organizações, inclusive como uma estratégia de } \\
\text { sobrevivência para estas estruturas (KENDAL; } \\
\text { ROLLINS, 2003; CRAWFORD, 2000; KERZNER, } \\
\text { 2001(b)). Visões evolutivas através da percepção de } \\
\text { valor e em níveis de maturidade, também são } \\
\text { apresentadas como propostas para implementação } \\
\text { de escritórios de gerenciamento de projetos } \\
\text { (KERZNER, 2001(b); TUCKER; AGOPIAN, 2006). }\end{array}$ & $\begin{array}{l}\text { CLELAND, D. I. Project management: strategic design } \\
\text { and implementation. New York: McGraw-Hill, 1999. } \\
\text { CRAWFORD, J. K. The strategic project office: a guide } \\
\text { to improving organizational performance. USA: CRC } \\
\text { Press, 2002. } \\
\text { DICKINSON, M. W; THORNTON, A. C.; GRAVES, S. } \\
\text { Technology Portfolio Management: Optimizing } \\
\text { Interdependent Projects Over Multiple Time Periods. } \\
\text { IEEE - Transactions on engineering management, v. 48, } \\
\text { n. 4, p. 518-527, 2001. } \\
\text { FRAME, Davidson; BLOCK, Thomas. The Project Office. } \\
\text { New York: Crisp Publications Inc., 1998. } \\
\text { KENDALL, G.; ROLLINS, S. Advanced project portfolio } \\
\text { management and the PMO: multiplying ROI at warp } \\
\text { speed. Boca Raton: J.Ross Publising Inc., 2003. } \\
\text { KOYAMA, H. H; TASSEL, R. V. How to trim Capital } \\
\text { Spending by 25 percent. The McKinsey Quarterly, n.3, } \\
\text { 1998. } \\
\text { KERZNER, H. Project management: a system approach } \\
\text { to planning, scheduling and controlling. New York: John } \\
\text { Wiley \& Sons, 2001 (a). } \\
\text { KERZNER, H. Strategic planning for project management } \\
\text { using a project management maturity model. New York: } \\
\text { John Wiley \& Sons, 2001 (b). } \\
\text { Best practices on implementation. New York: John Wiley } \\
\text { \& Sons, 2004. } \\
\text { MEREDITH, J. R; MANTEL, S. J. Project management : a } \\
\text { managerial approach. New York: Wiley \& Sons, 2000. } \\
\text { RAD, Parviz; LEVIN, Ginger. The advanced project } \\
\text { management office: a comprehensive look at function and } \\
\text { implementation. Florida: CRC Press, 2002. } \\
\text { TUCKER, Chuck; AGOPIAN, Hilda. Taking your PMO to to } \\
\text { the Next Stage. USA: Gartner Institute - EXP Premier - } \\
\text { march, 2006. }\end{array}$ \\
\hline
\end{tabular}

Tabela 4 - Resumo da Bibliografia: Escritórios de gerenciamento de projetos. 
Nas seções seguintes, apresenta-se o modelo teórico construído a partir desta literatura e como elemento de apoio na apresentação das relações e hipóteses formuladas, desenvolveu-se também um fluxo de processos ${ }^{2}$ de negócio para ilustrar o caminho de formação de um porta-fólio de projetos corporativos dentro de um planejamento estratégico e orçamentário. A figura 1 ilustra esse fluxo e este será reutilizado nas próximas seções em versões diferentes e evolutivas, com objetivo de posicionar cada um dos tópicos dentro do contexto deste estudo.

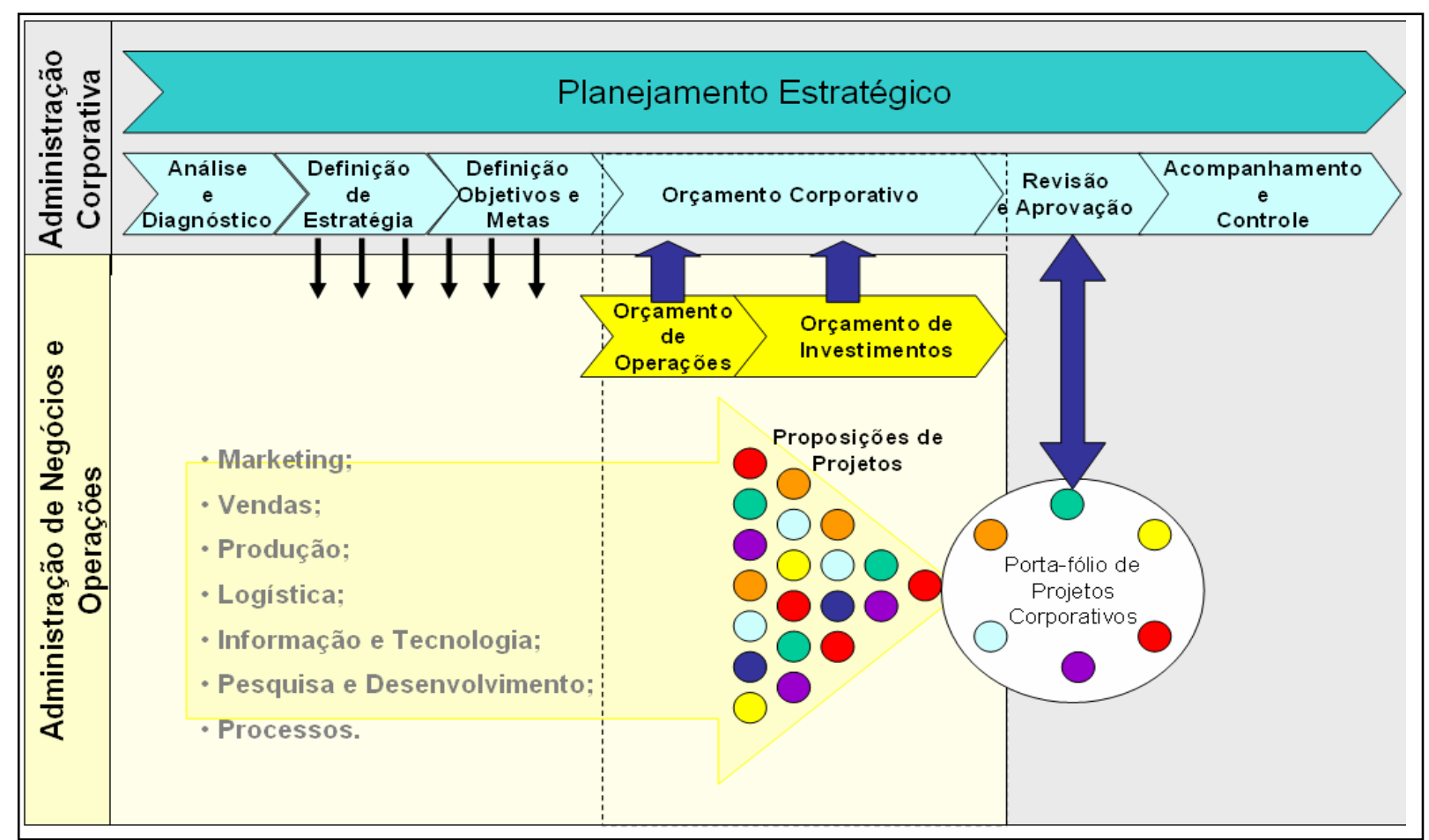

Figura 1 - Formação de porta-fólio de projetos dentro do planejamento estratégico e orçamentário. A coluna da esquerda indica as hierarquias envolvidas em cada um dos processos indicados pelas setas largas. As setas menores indicam o fluxo de informação que permeia entre os envolvidos no processo. Os círculos coloridos fazem referência às diversas proposições de projetos a serem orçados e aprovados no componente de orçamento de investimentos e tem origem nas diversas áreas e departamentos de uma organização. Após a submissão e aprovação, forma-se o porta-fólio de projetos corporativo, indicado pelo circulo maior a esquerda.

\footnotetext{
${ }^{2}$ Segundo Aurélio, um processo é definido como a maneira pela qual se realiza uma operação, segundo determinadas normas, métodos e técnicas (AURÉLIO, 1999). Em um cenário de negócio, um processo corresponde a um grupo de tarefas relacionadas que juntas criam valor para um demandante ou usuário consumidor dos produtos a que um processo propõe-se produzir (HAMMER; CHAMPY, 2001). A emissão de uma fatura, a produção de um bem de consumo ou ainda a venda de um produto podem ser representados através de uma forma especial de processo orientada à ambientes de negócio (BECKER; KUGELER; ROSEMANN, 2003). Existem várias formas para a representação de processos e em geral essas se encontram em formato gráfico. Neste trabalho não existe a intenção de utilizar-se um método rigoroso de representação gráfica de processos e em geral estes estarão sendo explorados de forma qualitativa, em um baixo nível de detalhamento e graficamente explora alguns elementos da proposta da ferramenta ARIS (Architecture of Integrated Information System) (SCHEER et al, 2002).
} 


\section{Modelo Teórico}

\subsection{Cibernética organizacional e o modelo de sistema viável}

A visão Newtoniana de percepção da realidade, através de noções de causa-efeito, permeou o pensamento científico até o início do século $X X$ e estabeleceu um modelo mecanicista e reducionista na abordagem de problemas que as ciências naturais se propuseram a estudar. Essa visão depara-se com grandes dificuldades quando o problema em estudo trata estruturas que apresentam alto grau de complexidade, interações dinâmicas e em uma situação que revela uma organização interna, tais como presentes em organismos vivos e sistemas sociais humanos.

Sob o enfoque da Física Clássica, um sistema em estudo é visto como fechado e como um agregado de componentes, em que o todo é igual à soma de suas partes. Os princípios da Termodinâmica estabelecem que os acontecimentos físicos dirigem-se para estados de máxima probabilidade e, por conseqüência, de máxima desordem. Por outro lado, em sistemas biológicos e sociais, a visão de sistema fechado é incompatível com a realidade observada. A presença de noções como as de crescimento, estabilidade, diferenciação, ordem hierárquica, dominância, controle e competição, bem como a ordem interna apresentada pelos organismos vivos acabam por gerar uma série de dificuldades na utilização destes modelos epistemológicos (BERTALANFFY, 1975).

Essas limitações e dificuldades motivaram a criação de novas abordagens, tais como a Teoria da Complexidade, a Teoria Geral dos Sistemas, bem como a Cibernética. O objetivo das próximas seções é o de apresentar conceitos e princípios básicos da Cibernética e do Modelo de Sistema Viável que foram utilizados pelo presente trabalho. 


\subsubsection{Sistemas e as organizações sociais}

De forma simples podemos definir que um sistema é constituído por um conjunto de funcionalidades das quais suas partes dependem e interagem entre si (BERTALLANFY, 1999; BEER, 1969; WIENER, 1948; ROBERTS et al., 1983; JACKSON, 2003).

Podemos identificar uma diversidade de sistemas em diferentes cenários:

- Físicos, tal como um sistema de rios em uma bacia hidrográfica;

- Biológicos, tal como encontrado em organismos vivos;

- De engenharia, tal como no projeto de uma máquina;

- Abstratos, tal como em modelos filosóficos;

- Sociais, tal como uma família;

- Nas atividades humanas, tal como nos sistemas para garantia de qualidade.

Para sistemas sociais e organizacionais, mesmo diante de propostas como a da Teoria da Complexidade, Teoria Geral dos Sistemas ou da Cibernética, verifica-se uma série de dificuldades na modelagem e simulação destes ambientes, principalmente devido aos seguintes fatores:

- Nos sistemas sociais e organizacionais, boa parte das situações e interações identificadas são de natureza não-lineares, recursivas e de mútua causalidade (FORRESTER, 1999(b); BEER, 1969; BERTALLANFY, 1999).

- Nesses tipos de sistemas, onde seres humanos interagem e agem sob a influência do próprio ambiente que estão criando, definem-se propósitos secundários. Desta forma, é dito que sistemas sociais e organizacionais possuem múltiplos objetivos ou propósitos. Adicionalmente, devemos considerar que propósitos, ainda que pré-estabelecidos, são figuras que emanam da mente humana e, portanto, estão sujeitos a diferentes 
modelos mentais encontrados nos indivíduos que desempenham atividades em um sistema (JACKSON, 2003; FLOOD, 2002; BEER, 1969, 1979; BERTALANFFY, 1975).

- Para sistemas de múltiplos propósitos, onde se encaixam os sistemas sociais e organizacionais, o atributo de limite, definido para caracterizar a fronteira de um sistema, raramente pode ser declarado com exatidão (JACKSON, 2003).

- Presença de noções como as de crescimento, diferenciação, ordem hierárquica, dominância, controle e competição, que não são facilmente tratados diante de interpretações de caráter quantitativas (BERTALANFFY, 1975; BEER, 1969).

Em contrapartida, modelos aproximados podem ser produzidos a partir de abordagens diferentes, gerando representações satisfatórias a propósitos bem específicos. Para o caso de sistemas organizacionais, o uso de metáforas sistêmicas é uma possibilidade e estas podem ser classificadas em cinco grupos (FLOOD, 2002):

- Metáfora da máquina - Neste modelo de representação, a ênfase se encontra na eficiência das partes. Esta metáfora é bastante adequada quando consideramos a representação de:

- Tarefas a serem executadas sob rígido controle;

- Produção repetitiva de um simples produto;

- Quando as pessoas envolvidas no modelo seguem instruções de forma padrão;

- O sistema está imerso a um ambiente estável.

- Metáfora orgânica - Neste modelo, existe uma extensa rede de relacionamentos entre as partes do sistema e o sistema interage com o ambiente externo de forma intensa. Nele, persiste a necessidade de garantir-se a propriedade da homeostase e as interações internas ocorrem em busca de um modelo de auto- 
regulação. A visão orgânica é adequada quando o modelo a ser representado apresenta:

- Relações abertas em um ambiente de constante mudança;

- Quando existem necessidades a serem supridas para que se garanta a sobrevivência do sistema;

- Quando o sistema deve produzir respostas rápidas e eficientes ou ainda mudanças internas.

- Metáfora neuro-cibernética - Também conhecido como visão de sistema viável, esta metáfora possui ênfase em representar sistemas que possuem a propriedade de aprendizado e controle, diferentemente de uma capacidade de adaptação passiva. Neste modelo, o conceito de controle está vinculado a um conjunto de variedades de situações a serem administradas. É aderente quando depara-se com:

- Sistemas orientados a objetivos e aprendizado;

- Ambientes com um alto grau de incerteza;

- Necessidade de inovação e criatividade.

- Metáfora cultural - Nesta visão, a cultura humana, formal e informal, é levada em consideração. Nesta metáfora, o nível de abstração é bastante alto na medida em que o conceito de cultura pode extrapolar a capacidade de percepção do investigador. É uma visão emergente para as representações que buscam estudar modelos de gestão de qualidade.

- Metáfora política - Aplicável quando o sistema em estudo possui relacionamentos que envolvem conflitos, competição e busca pelo poder.

Uma metáfora bastante aceita devido aos resultados obtidos e sua simplicidade em relação às demais é a neuro-cibernética, que é a adotada no presente trabalho. 


\subsubsection{Cibernética}

A Cibernética foi definida por Norbert Wiener como a ciência de controle e comunicação, nos animais e nas máquinas (WIENER, 1948). Os aspectos operacionais dessa ciência não se prendem ao campo que se queira aplicá-la. Com a expansão de seus conceitos, a Cibernética tornou-se o estudo de como sistemas biológicos, sociais, econômicos e de engenharia são controlados e regulados (BEER, 1979; ROBERTS et al., 1983)

Trata-se de uma ciência que está interessada no comportamento, nas respostas e nas relações entre as partes que compõem um sistema. A ênfase não se encontra em determinar como um componente de um sistema produz uma reposta, mas sim em identificar as suas possíveis respostas diante de um conjunto de situações. Essa abordagem mostra-se bastante promissora quando os sistemas estudados apresentam alta complexidade e intensa relação como o ambiente externo.

O conceito de retroalimentação, ou feedback, é fundamental na Cibernética e foi introduzido em 1948, quando Norbert Wiener demonstrou que um sistema que busca um estado que expressa o seu próprio objetivo (estado meta), deve se valer de dois conceitos fundamentais: controle e comunicação. (WIENER, 1948). A informação relativa a um estado assumido na saída de determinado sistema, que esteja em desacordo com o seu objetivo ou propósito, é transmitida a um componente de controle que atua na forma de ação corretiva interna, com o objetivo de trazer o sistema de volta ao estado desejado. A figura 2 ilustra o conceito de retroalimentação.

Com a introdução do conceito de retroalimentação, abrem-se novos caminhos para a introdução de métodos de auto-regulação e controle na modelagem de sistemas. A retroalimentação trata-se de um processo de comunicação que reage a cada entrada de informação. Se a informação faz aumentar o desempenho do sistema, esta é considerada uma retroalimentação positiva, caso contrário, negativa. $O$ equilíbrio dinâmico, um dos conceitos essenciais da Teoria da Complexidade, é 
alcançado através do acoplamento não linear de retroalimentações positivas e negativas.

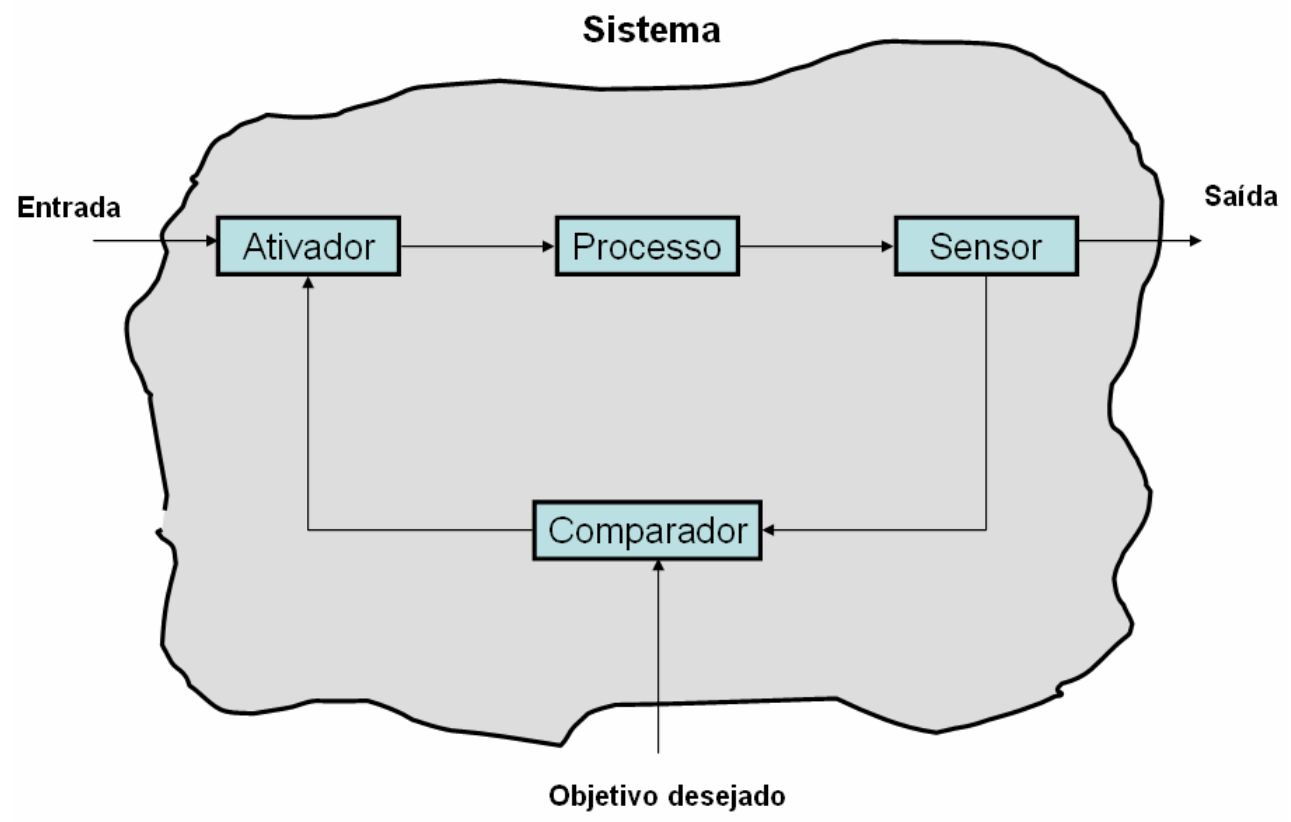

Figura 2 - Modelo de Retroalimentação Negativa (JACKSON, 2003, p. 8, tradução nossa )

A busca por um equilíbrio dinâmico, ou de auto-regulação dentro de um sistema é definida como uma ação de homeostase.

A homeostase é uma propriedade auto-reguladora de um sistema ou organismo que permite manter o estado de equilíbrio de suas variáveis essenciais ou do meio ao qual ele se encontra imerso. Os processos homeostáticos são desempenhados por dispositivos de controle (homeostatos) que tem por objetivo manter certa variável de um sistema, ou subparte dele, dentro de certos limites através de mecanismos autoreguladores (BEER, 1969; FLOOD, 2002).

Sob a perspectiva da Cibernética, os sistemas biológicos e sociais apresentam-se excessivamente complexos, operando e adaptando-se essencialmente por princípios de homeostase. (BEER, 1969). 
Para lidar com esta excessiva complexidade, uma das importantes facilidades proporcionadas pela abordagem da Cibernética é a sua habilidade de manipular o conceito de caixa preta. O conceito de caixa preta refere-se à possibilidade de representar um determinado componente de um sistema apenas pelas propriedades de respostas que ele produz, sem se interessar pela forma com a qual ele processa e produz essas respostas. A ênfase da Cibernética encontra-se no comportamento de cada uma das partes de um sistema e este é estudado descobrindo-se as correlações lógicas e estatísticas entre as informações que entram e saem de um componente a ser representado.

Diante dos conceitos de retroalimentação, caixa preta e da necessidade de atuar através de dispositivos homeostáticos, a informação torna-se um elemento fundamental dentro da Cibernética, uma vez que esta fornece os insumos necessários para determinação do modo e nível de homeostase a ser aplicado em uma determinada situação de desequilíbrio. A informação reduz a incerteza na resposta de um determinado componente do sistema e está diretamente relacionada ao nível de entropia do ambiente interno e externo deste. De fato, a informação é uma das formas pelas quais se pode reduzir a entropia, ou desorganização, em um sistema (BERTALANFFY, 1975) ${ }^{3}$.

A informação traz, portanto, a leitura dos estados internos e externos de um ambiente que podem ser interpretados como a diversidade ao qual um sistema está sujeito e deve responder. A Cibernética trata esta diversidade pelo conceito de variedade, que aqui terá um especial destaque devido ao seu uso intensivo na análise e interpretações dos dados apresentados no estudo de caso deste trabalho.

\footnotetext{
${ }^{3}$ Em consideração às peculiaridades dos sistemas abertos e fechados, Bertalanffy comenta que uma das limitações das abordagens convencionais da Física Clássica, no que se diz respeito à representação de sistemas complexos com algum nível de organização interna, deriva do fato que ela faz uso freqüente de premissas que levam a considerar os sistemas em análise como fechados. Sob essas considerações, o princípio de entropia leva a concluir que um sistema irá, naturalmente, atingir um estado de máxima probabilidade ou de maior desorganização interna. Neste ponto, cria-se uma falsa percepção de que a realidade observada em estruturas mais complexas, tal como nos organismos vivos, violam princípios físicos quando estabelecem uma ordem interna ao invés de caminharem para um estado de caos. Bertalanffy, porém, propõe que essa contradição não se encontra em uma possível violação de princípios físicos, mas sim de não se considerar que os organismos vivos são sistemas abertos e que estes podem importar entropia negativa, compensando a sua desordem interna. (BERTALANFFY, 1975).
} 


\subsubsection{Conceito de variedade}

A alta complexidade de um sistema reside no volume total de combinações possíveis de diversidades, ou variedades a serem tratadas de forma simultânea, bem como das combinações que uma determinada parte de um sistema deve oferecer como resposta às variedades identificadas em um ambiente.

O termo variedade foi introduzido pela primeira vez por Ashby em 1956 e faz referência ao número de possíveis estados que um sistema pode assumir (JACKSON, 2003). De acordo com a Lei de Ashby, que trata de requisitos da variedade, os sistemas podem ser plenamente controlados somente se os indivíduos responsáveis pelo mesmo possuírem capacidade de administrar com o mesmo grau de variedade apresentado pelo sistema em questão (ASHBY, 1957).

Para Beer, a análise de um ambiente organizacional, utilizando os princípios da Cibernética, toma como ponto de partida o conceito de variedade e a premissa de que, para se obter um controle efetivo de uma operação, a variedade deve ser balanceada. Da mesma forma, pode-se considerar que a complexidade de um sistema possui relação direta e proporcional com volume de variedades a que ele está sujeito e, portanto, a variedade pode ser também considerada como uma medida de complexidade (BEER, 1969, 1979).

Nos dias de hoje, os sistemas sociais e organizacionais apresentam um alto grau de complexidade $^{4}$ em uma dinâmica manifestada por altas taxas de mudanças. Essas mudanças são caracterizadas pela Cibernética como distúrbios que mudam as características das variedades a serem administradas dentro de um sistema. Para administrar esses cenários, os gestores das organizações buscam ações que levem

\footnotetext{
${ }^{4}$ No parágrafo acima, não há intenção de relacionar a complexidade como uma propriedade indesejável. É muito comum encontrar na literatura uma associação direta entre complexidade e dificuldade. No entanto, muitos autores defendem que a complexidade é essencial para viabilizar estruturas evolutivas ou mesmo a vida na sua forma mais básica (MATURANA; VARELA, 2001). A complexidade interna, existente na extensa rede de relacionamentos de sistemas abertos, dissipativos e não-lineares, permite estabelecer o equilíbrio dinâmico observado nestes tipos de estruturas. As formas superiores de organização encontradas na natureza são, em geral, viabilizadas por esta característica de complexidade (PRIGOGINE; STEGERS, 1984).
} 
à redução desta variedade ou ainda ações que possam aumentar a sua própria variedade, permitindo aumentar a sua capacidade de lidar com as adversidades.

A lei dos requisitos de variedade concebe que somente a variedade pode destruir a variedade. $\mathrm{O}$ balanceamento da variedade em um sistema organizacional é possível através de duas abordagens: reduzir a variedade do meio ou amplificar a própria variedade. Este processo de balanceamento é conhecido como engenharia de variedade (ASHBY, 1957; BEER, 1979).

Por outro lado, a idéia de manter-se um controle da variedade não pode ser confundida com a intenção de supressão da mesma. A habilidade de um determinado subsistema organizacional em lidar com mudanças do ambiente está diretamente ligada à sua capacidade de atuar com autonomia. Se a administração de uma determinada organização decide por restringir a variedade neste sistema, ou em parte dele, de forma excessiva, a capacidade adaptativa do mesmo pode ser comprometida ${ }^{5}$ (BEER, 1979; JACKSON, 2003).

Pode-se considerar que as empresas, enquanto sistemas que buscam adaptar-se a um ambiente, atuam concomitantemente nas duas abordagens na medida em que restringem ou ampliam suas competências internas ou mercados de atuação. A transferência de atividades internas de um sistema para o meio externo, em um outro sistema mais especializado, tal como verificado em um processo de terceirização de serviços, é um exemplo de balanceamento da variedade pela redução de variedade interna, pois o subsistema remanescente fica reduzido a atividades de monitoramento e controle.

\subsubsection{O Modelo de sistema viável}

\footnotetext{
${ }^{5}$ Faz-se aqui um parêntesis para estabelecer-se uma correlação interessante entre o nível de variedade interna e o nível de especialização de um sistema. Maturana e Varela afirmam que a especialização excessiva pressupõe um conjunto específico de estados ao qual um determinado sistema deve responder com máxima eficiência. Em ambientes instáveis e sujeitos a constantes mudanças, essa especialização excessiva pode contrapor-se às habilidades deste mesmo sistema em adaptar-se ao meio na velocidade necessária. (MATURANA e VARELA, 2001).
} 
Para Beer, os problemas de desempenho verificados nas organizações podem ser analisados sob a perspectiva da violação de algum princípio da Cibernética. Os princípios encontrados na Cibernética são pertinentes na análise de problemas organizacionais, principalmente pelos seguintes fatores (BEER, 1979):

- Os novos problemas sociais e organizacionais surgem, principalmente, devido à inadequação da visão tradicional de controle $^{6}$ aos novos graus de complexidades verificados nas configurações e hierarquias organizacionais, tecnologias disponíveis e informações demandadas;

- Face aos novos problemas e complexidades verificados, as práticas tradicionais da administração mostram-se elementares e suas respostas são baseadas em abordagens isoladas dos contextos;

- A maior preocupação dos administradores é o controle;

- As organizações são projetadas e estruturadas para que se atinja um conjunto de objetivos de forma o mais eficiente possível;

- Os objetivos de uma organização podem mudar de acordo com as alterações ocorridas em um ambiente. As repostas necessárias às mudanças observadas devem ser baseadas no autoquestionamento e aprendizado.

$\mathrm{Na}$ busca de desenvolver-se um modelo mais preciso e prático de como as dinâmicas desenvolvem-se dentro das organizações, Beer produz o que ele denominou de modelo de sistema viável (Viable System Model - VSM ). O VSM foi concebido, dentro da metáfora neuro-cibernética de visão sistêmica das organizações humanas, como uma estrutura definida por cinco componentes denominados de sistemas. A cada um destes cinco sistemas são atribuídas respectivamente as atividades de:

\footnotetext{
${ }^{6}$ Em relação à visão tradicional do conceito de controle, Beer comenta sobre o equívoco a que ela remete pela sua associação com uma ação de coerção baseada em princípios de causalidade. $\mathrm{Na}$ Cibernética, o conceito de controle está relacionado a manifestações de homeostases com objetivos de viabilizar estados de auto-regulação (BEER, 1969). Ashby complementa indicando que o controle de um sistema é necessariamente dependente de sua capacidade de regulação de estados internos em variáveis específicas (ASHBY, 1957).
} 
- Implementação;

- Coordenação;

- Controle Operacional;

- Desenvolvimento;

- Políticas.

A modelagem de sistemas organizacionais através do VSM deve estar orientada pelas seguintes considerações (FLOOD, 2002):

- Preocupação com os elementos considerados essenciais na estruturação e manutenção da identidade e integridade de uma organização;

- O uso de recursividade nos modelos de controle e comunicação. Isto significa que os mesmos princípios do VSM podem e devem ser utilizados na modelagem das subpartes de um mesmo sistema;

- O direcionamento e integração das subpartes de um sistema ou unidades devem ser promovidos por uma relação de hierarquia em uma estrutura de níveis de administração;

- A estrutura de comando e controle das subpartes de um sistema possuem autonomia limitada ao contexto de sua funcionalidade e dos problemas relacionados a elas.

O termo viável, a que se refere o modelo, deriva da habilidade de um sistema manter-se operacional, perpétuo e capaz de adaptar-se às condições que o ambiente Ihe impõe. No VSM, qualquer organização que deseje manter-se viável ao longo do tempo deve garantir que as funções de seus cinco sistemas sejam executadas de forma adequada. Para tanto, deve-se atender a quatro princípios cibernéticos (BEER, 1979):

1. A variedade a ser administrada por uma organização corporativa, tanto do meio externo quanto às relacionadas à suas atividades produtivas, deve estar compensada pela variedade interna disponível na 
organização, respeitando-se a viabilidade financeira da empresa e integridade dos recursos humanos.

2. Os canais de comunicação dentro de uma organização devem estar dimensionados para suportar a transmissão do volume de informações relevantes, necessários à administração da variedade à que a organização está sujeita;

3. A variedade de um canal de comunicação deve ser, pelo menos, igual a variedade do receptor da informação;

4. Os três primeiros princípios devem ser ciclicamente revistos e mantidos ao longo do tempo.

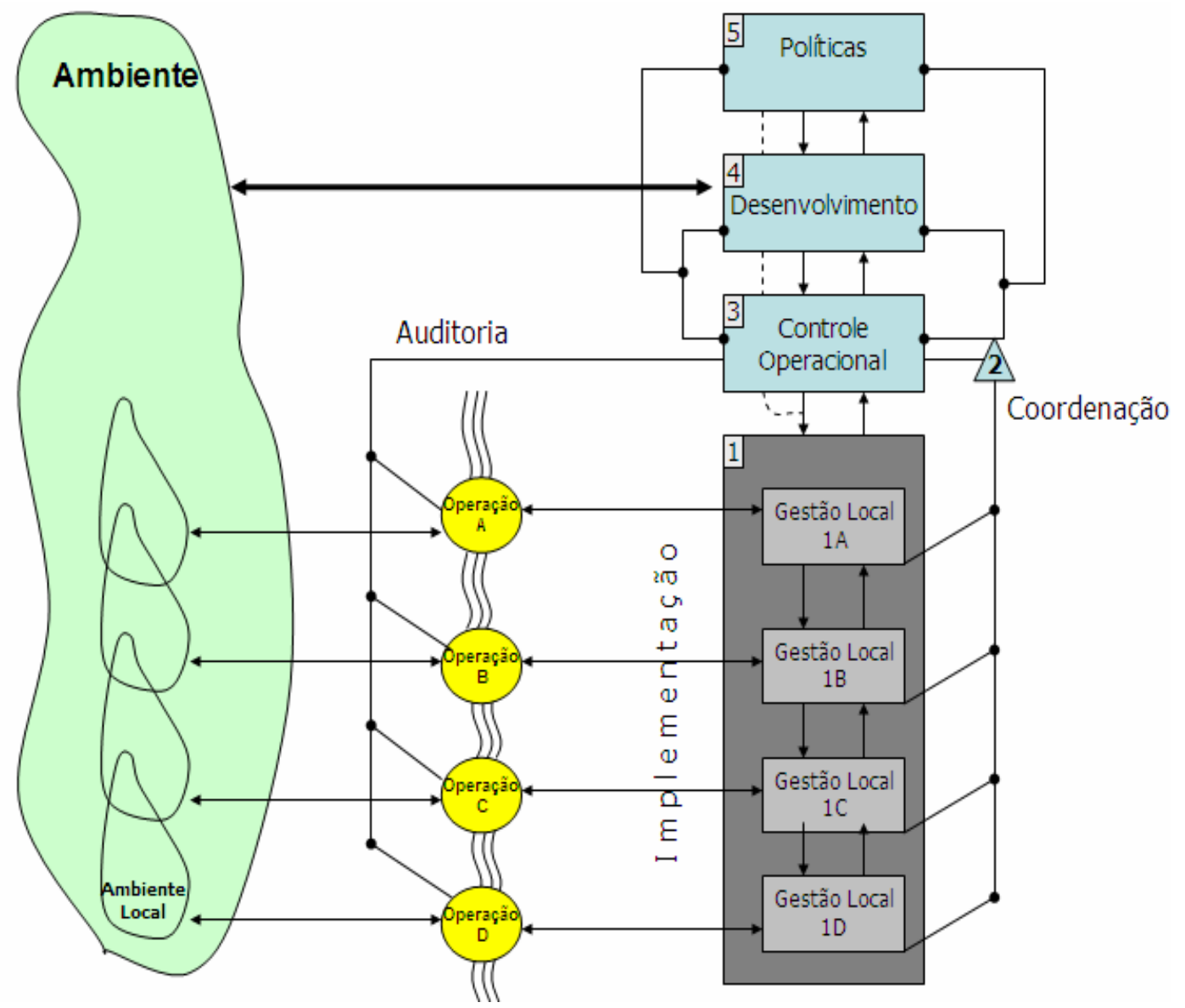

Figura 3 - O Modelo de Sistema Viável. Os índices numéricos indicam o sistema correspondente às várias funções, a saber, Implementação; Coordenação; Controle Operacional; Desenvolvimento e Políticas. Os canais de informação entre os cinco sistemas são estabelecidos por uma hierarquia de conteúdos e variedades pertinentes a cada uma das atribuições dos sistemas que compõem o VSM e estão ilustrados por setas. A linha tracejada, que segue do sistema 1 até o sistema 5, representa sinais de alerta que fazem referência aos riscos a que o sistema 1 pode estar sujeito. Os relacionamentos de coordenação e controle aparecem, ilustrados como as linhas terminadas por nós, interligando as diversas partes do modelo.

(JACKSON, 2003, p. 92, tradução nossa) 
Portanto, o VSM pode ser considerado como um modelo que está baseado em atribuições que estabelece um balanço entre o controle, informações, variedades e autonomias à que cada um de seus cinco sistemas estão sujeitos. Os cinco sistemas que compõem o VSM são indicados na figura 3 por índices numéricos e possuem as seguintes funções e características (BEER, 1979; JACKSON, 2003; FLOOD, 2002):

\section{Sistema 1}

- Consiste das várias partes da organização interessadas na implementação e execução das tarefas relacionadas ao sistema produtivo final, propósito da organização. Esses seriam os elementos operacionais de uma organização;

- As Unidades classificadas neste nível são autônomas e possuem níveis hierárquicos de comando;

- Cada uma das unidades relaciona-se com os seus ambientes locais e lida com a variedade encontrada neles;

- Pelo conceito de recursividade, elas apresentam todas as funcionalidades verificadas no VSM e podem ser representadas da mesma forma que o sistema global.

\section{Sistema 2}

- Consiste das várias regras e regulamentos que atuam sobre as unidades que compõem o sistema 1;

- Busca garantir que as diversas partes que constituem o sistema 1 atuem de forma harmônica.

\section{Sistema 3}

- Tem como papel efetuar um controle operacional do sistema 1 e tarefas administrativas de apoio, tais como as exercidas pelas áreas de recursos humanos ou financeiros;

- Mantém a estabilidade interna do sistema global;

- Interpreta as políticas e decisões da alta direção da empresa;

- Garante a implementação e cumprimento das políticas definidas;

- Inspeciona e promove auditorias nos sistemas 1 e 2 . 


\section{Sistema 4}

- Funciona como uma central de inteligência do sistema. O processo de tomada de decisão é inteiramente dependente deste sistema;

- Tem como papel principal o de capturar todas as informações relevantes sobre os ambientes aos quais a organização está submetida (interno e externo);

- Provê uma interpretação destes ambientes;

- Distribui as informações compiladas do ambiente dentro da hierarquia do sistema, de acordo com o grau de importância e pertinência das informações;

- Em geral, contempla atividades como de planejamento corporativo, marketing, pesquisa e desenvolvimento e relações públicas.

\section{Sistema 5}

- Responsável em prover a direção de toda a organização;

- Determina as políticas internas em função das informações fornecidas pelo Sistema 3 e 4;

- Provê resposta para necessidades relevantes de tomadas de decisão que não puderam ser tratadas pelos sistemas 1, 2, 3 e 4;

- Provê uma arbitragem sobre possíveis impasses internos ou externos, baseadas nas funções e informações desempenhadas pelos sistemas 3 e 4.

Os canais de informação entre os cinco sistemas são estabelecidos por uma hierarquia de conteúdos e variedades pertinentes a cada uma das atribuições dos sistemas que compõem o VSM e estão ilustrados na figura 3 por setas. Outro componente de comunicação indicado no modelo representa a comunicação de sinais de alerta (Algedonic Signal ${ }^{7}$ ), que faz referência aos riscos a que o sistema 1 pode estar sujeito e deve, portanto, ativar ações de respostas imediatas nos sistemas 2, 3, 4 e 5. A linha tracejada, apresentada na figura 3 e que segue do sistema 1 até o sistema 5 , representa este canal de informação.

\footnotetext{
${ }^{7}$ O termo "Algedonic" foi deliberadamente deixado na indicação entre parêntesis, por outro lado o autor deste trabalho não encontrou referências que indicasse a origem do termo. $O$ termo encontra-se definido na língua inglesa.
} 
Os relacionamentos de coordenação e controle aparecem, ilustrados na figura 3, como as linhas terminadas por nós, interligando as diversas partes do modelo.

Em relação aos cinco sistemas, o sistema 1 é tido como o componente mais importante do VSM, pois é dele a responsabilidade produtiva que garante a geração dos recursos necessários à sobrevivência de todo o organismo. Os sistemas 2, 3, 4 e 5 existem meramente para garantir a integridade e funcionamento adequado dos sistemas 1 (FLOOD, 2002). O VSM determina que a viabilidade de um modelo é extremamente dependente da relação harmônica entre os sistemas 1 e as ações de comunicação e controle dos sistemas 2, 3, 4 e 5, que devem estar em sintonia com os objetivos do organismo como um todo e com as necessidades demandadas pelo sistema 1.

Neste sentido, uma ameaça à viabilidade de um sistema organizacional pode não só ser devida ao comportamento do ambiente externo, mas também do comportamento autônomo de algum dos cinco sistemas. Esta consideração reforça a tese de que a visão sistêmica deve estar sempre presente nas atividades de tomada de decisão dentro das organizações ${ }^{8}$. A integridade do sistema 1 pode ser comprometida se algum dos outros quatro sistemas assumirem um comportamento autopoiético ${ }^{9}$, que pode estar em não conformidade com os objetivos e necessidades gerais do sistema organizacional (JACKSON, 2003).

Segundo Beer, os sistemas 1, 2 e 3 desenvolvem aquilo que ele denomina como gestão autônoma da organização. Esses três sistemas promovem uma estabilidade

\footnotetext{
${ }^{8}$ Como reforço à necessidade da visão sistêmica, Beer argumenta que muito dos fracassos em tentativas de otimização de áreas ou departamentos em organizações corporativas deve-se ao uso de abordagens reducionistas, pois elas não levam em conta a visão orgânica da empresa, as interações entre as suas partes e o impacto de mudanças locais em um contexto maior (BEER, 1969).

${ }^{9} \mathrm{O}$ termo autopoiético deriva do grego onde "poio" significa criação ou formação e portanto, remete a um estado de auto-criação e auto-definição (BEER, 1979). Maturana e Varela referem-se a autopoiese como forma de qualificar um organismo vivo pela presença de mecanismos de autodefinição e preservação de sua organização interna (MATURANA; VARELA, 2001). Beer estende o uso deste mesmo conceito, relacionando a autopoiese com a viabilidade de um sistema organizacional (BEER, 1979). No trecho acima, a intenção não é a de indicar a autopoiese como um comportamento indesejado para os organismos vivos ou para uma organização social. A citação acima remete à hipótese da autopoiese se manifestar em uma subparte de um organismo, porém em um comportamento cuja autonomia é dissonante com as necessidades das demais partes do sistema onde ela se relaciona.
} 
interna e a otimização do desempenho como um todo, sempre baseado em um modelo de diretrizes pré-definidas. Muito embora essa autonomia esteja presente, o conjunto de sistemas 1, 2 e 3 não possui a capacidade de obter uma visão global do ambiente organizacional e é incapaz de responder às ameaças ou oportunidades identificadas no ambiente interno ou externo. Essas atribuições são competências endereçadas aos sistemas 4 e 5 e ocorrem pela avaliação do ambiente interno e externo, análise e tomada de decisão de cunho tático e estratégico (BEER, 1979).

A tomada de decisão em um nível estratégico está, portanto, intrinsecamente relacionada às atividades desempenhadas pelos sistemas 4 e 5 . Pode-se também concluir que a estratégia de uma organização também é definida nestes dois sistemas.

Uma forma estruturada de desempenhar as atividades de formulação e implementação de estratégias corporativas pode ser expressa em termos de processos formais de planejamento estratégico e orçamentário que é o assunto da próxima seção (Seção 3.2). Em relação aos modelos de comunicação e controle, bem como à especialização demandada pelos processos de definição de investimentos na forma de projetos, nas seções 3.3 e 3.4 exploram-se as potencialidades verificadas na disciplina de gestão de porta-fólio de projetos e de estruturas denominadas como escritórios de gerenciamento de projetos.

Por outro lado, nestas três próximas seções (3.2, 3.3 e 3.4) não serão estabelecidas relações ou interpretações dos assuntos abordados com as propostas da Cibernética e do VSM. Estas relações serão estabelecidas na interpretação e análise do estudo de caso apresentado na seção 5 . 


\subsection{Planejamento estratégico e orçamentário}

A origem da palavra estratégia vem do termo grego "Strategos", que combina "stratos", expressão que significa exército e "ag", que significa liderar. O termo foi utilizado amplamente pelos exércitos para determinar as ações ofensivas, com o único propósito de alcançar a vitória sobre o inimigo.

Após a Segunda Revolução Industrial, este termo passou a ser adaptado ao contexto de negócios, com o intuito de se caracterizar um processo sistemático de preparação de uma agenda de ações orientadas a conquistas de mercados e maior lucratividade nos empreendimentos. Após a Segunda Guerra Mundial, a escassez de recursos generalizada, principalmente na Europa e Estados Unidos, estimulou a formalização de um modelo de gestão orientado a um planejamento prévio de cunho estratégico. A primeira fase do planejamento estratégico floresceu na metade do século XX, nos Estados Unidos, na forma de planejamento financeiro ou orçamentário e este passou a ter uma aceitação continuamente crescente (TAVARES, 2000). O planejamento financeiro é definido como o processo de decidir o que a empresa irá empreender e operacionalizar com seus recursos dentro de um período específico de tempo. Neste caso, o principal dispositivo formal de empenho deste processo é o orçamento corporativo, que é uma demonstração dos planos em termos financeiros (ANTHONY, 1970).

Nos anos 1960, surgiu o planejamento de longo prazo, que extrapolava o contexto do planejamento financeiro uma vez que se passa a incluir uma reflexão dos impactos das decisões no longo prazo. Uma de suas características principais era o uso de projeções de tendências e análise de lacunas. Embora neste modelo o orçamento corporativo ainda prevaleça como base para implementação e controle dos planos estabelecidos, o modelo de planejamento financeiro ou orçamentário possui uma linha orientada a objetivos mais efetivos e de curto prazo, distanciandose dos objetivos do planejamento de longo prazo, que busca linhas de ações mais gerais e orientadas a períodos superiores aos anuais. Em meados de 1970, surgiu o planejamento estratégico (LUNKES, 2003). 
O processo da formulação de estratégia não pode ser considerado como uma evolução convergente para um único modelo. Um total de dez escolas representam a visão da construção de uma estratégia a partir de vários contextos e abordagens, sendo a escola de planejamento a mais difundida e aceita nos modelos corporativos (MINTZBERG; BRUCE, 2000).

Neste trabalho, o modelo que melhor representa a realidade estudada é o da escola de planejamento estratégico, cujos fundamentos e abordagens são apresentados a seguir.

\subsubsection{Planejamento estratégico}

O planejamento estratégico consiste em análises sistemáticas dos pontos fortes e fracos da empresa e das ameaças e oportunidades do ambiente em que ela opera e se relaciona. Destas análises, são delineados objetivos, estratégias e ações que devem ser implementadas (CUNHA, 2000 - apud LUNKES, 2003).

Para que um planejamento estratégico ocorra de forma adequada, é necessário entender a empresa como um todo, bem como suas relações com o ambiente em que ela atua. A visão sistêmica é fundamental, visto que resoluções tomadas, tendo como base análises isoladas e ou com horizontes limitados ou ainda incompletos, podem levar a resultados indesejáveis (LORANGE; VANCIL, 1977).

Através do planejamento estratégico, a empresa espera (REBOUÇAS, 1977):

- Conhecer e melhor utilizar seus pontos fortes;

- Conhecer e eliminar ou readequar seus pontos fracos;

- Conhecer e usufruir das oportunidades externas;

- Conhecer e evitar as ameaças externas;

- Desenvolver um plano de trabalho, estabelecendo:

- Premissas básicas que devem ser consideradas no processo;

- Expectativas de situações almejadas pela empresa; 
- Caminhos, inclusive alternativos, a serem seguidos pela empresa;

- O quê, por quê, como, quando, por quem, para quem e onde devem ser realizados os planos de ações estabelecidos;

- Como e onde alocar recursos humanos e materiais.

Como resultado de trabalho, o planejamento estratégico deverá apresentar os seguintes produtos finais:

- Direcionamento de esforços para pontos comuns;

- Consolidação do entendimento por todos os interessados da missão, dos propósitos, das estratégias, políticas, posturas, objetivos gerais, desafios, metas e projetos da organização;

- Estabelecimento de uma agenda de trabalho por um período de tempo que permita à empresa trabalhar nas prioridades estabelecidas.

Não há uma metodologia universal de aplicação para as atividades de planejamento estratégico, principalmente pelo fato de que as empresas diferem em tamanho, em tipos de operações, em forma de organização, em filosofia e estilo gerencial (LORANGE e VANCIL, 1977). Uma metodologia, manifestada por um processo formal, porém, deve ser utilizada para orientar o planejamento estratégico. Ainda que não exista um modelo universal, muitos modelos podem ser utilizados sob considerações de ajustes às condições e realidades internas e ambientais das empresas.

Mintzberg relata que existem centenas de modelos diferentes de planejamento estratégico, porém a maior parte se reduz às mesmas idéias básicas de avaliação através da técnica SWOT ${ }^{10}$ (MINTZBERG; BRUCE, 2000). Rebouças sugere as

\footnotetext{
${ }^{10}$ A técnica SWOT consiste da avaliação dos pontos fortes e fracos de uma organização, seguido da análise de oportunidades e ameaças que se verificam em um determinado ambiente. O termo SWOT deriva do anagrama em inglês: Strengths, Weakness, Opportunities and Threats. (PRITCHARD, 2001)
} 
seguintes fases (REBOUÇAS, 1997), que serão exploradas também a partir do modelo na ilustração da figura 1 (seção 2):

- FASE I: Diagnóstico estratégico - Nesta fase, também denominada de auditoria de posição, deve-se determinar "como se está". Esta fase é dividida em quatro outras etapas básicas, a saber:

- Identificação da visão - Identificam-se quais são as expectativas e os desejos dos acionistas, conselheiros e elementos da alta administração da empresa;

- Análise externa - Verificam-se as ameaças e oportunidades presentes no ambiente da empresa e as melhores maneiras de evitar ou usufruir dessas situações;

- Análise interna - Verificam-se pontos fortes, fracos e neutros da empresa;

- Análise dos concorrentes - Constitui-se uma análise externa e interna dos seus principais concorrentes. Somente através deste procedimento, o executivo poderá ter um posicionamento adequado perante seus concorrentes;

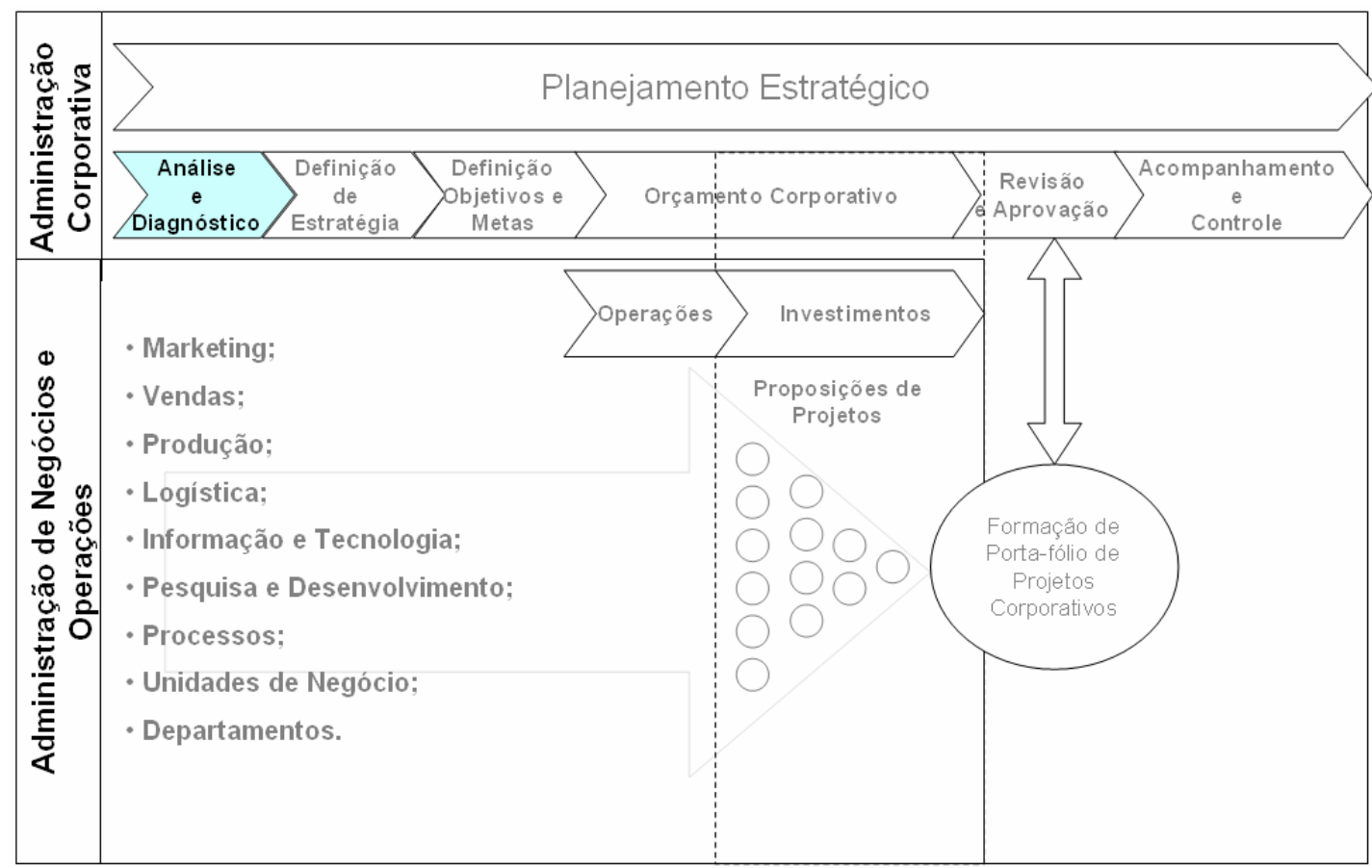

Figura 4 - Planejamento estratégico - Fase I- Diagnóstico Estratégico. A coluna da esquerda indica as hierarquias envolvidas em cada um dos processos indicados pelas setas largas. As setas menores indicam o fluxo de informação que permeia entre os envolvidos no processo. A alta direção determina "como se está". Esta fase é dividida em quatro outras etapas básicas: Identificação da visão; Análise externa; Análise interna; Análise dos concorrentes. 
- FASE II: Missão da empresa - Neste momento deve ser estabelecida a razão de ser da empresa, bem como seu posicionamento estratégico. Esta fase é dividida em quatro outras etapas básicas, a saber:

- Estabelecimento da missão da empresa - A missão da empresa deve ser definida de modo a satisfazer a alguma necessidade do ambiente externo;

- Estabelecimento dos propósitos atuais e potenciais Correspondem à explicitação dos setores de atuação no escopo da missão que a empresa já atua ou está avaliando a possibilidade de entrada;

- Estruturação e debate de cenários - Representam critérios e medidas para a preparação do futuro da empresa. Nesta fase ocorre o desenvolvimento de cenários que retratam determinado momento no futuro ou que detalham a evolução e a seqüência de eventos desde o momento atual até determinado momento futuro.

- Estabelecimento da postura estratégica - Define a maneira como a empresa se posicionará diante de seu ambiente, para que a mesma possa alcançar seus propósitos dentro da missão, respeitando sua situação interna e externa, definidas na FASE I - Diagnóstico estratégico.

- Estabelecimento de macro-estratégias e macro-políticas - a saber:

- Macro-estratégias: correspondendo às grandes ações ou caminhos que a empresa deverá adotar;

- Macro-políticas: correspondendo às grandes orientações que servirão como base de sustentação para as decisões de caráter geral que a empresa deverá tomar. 


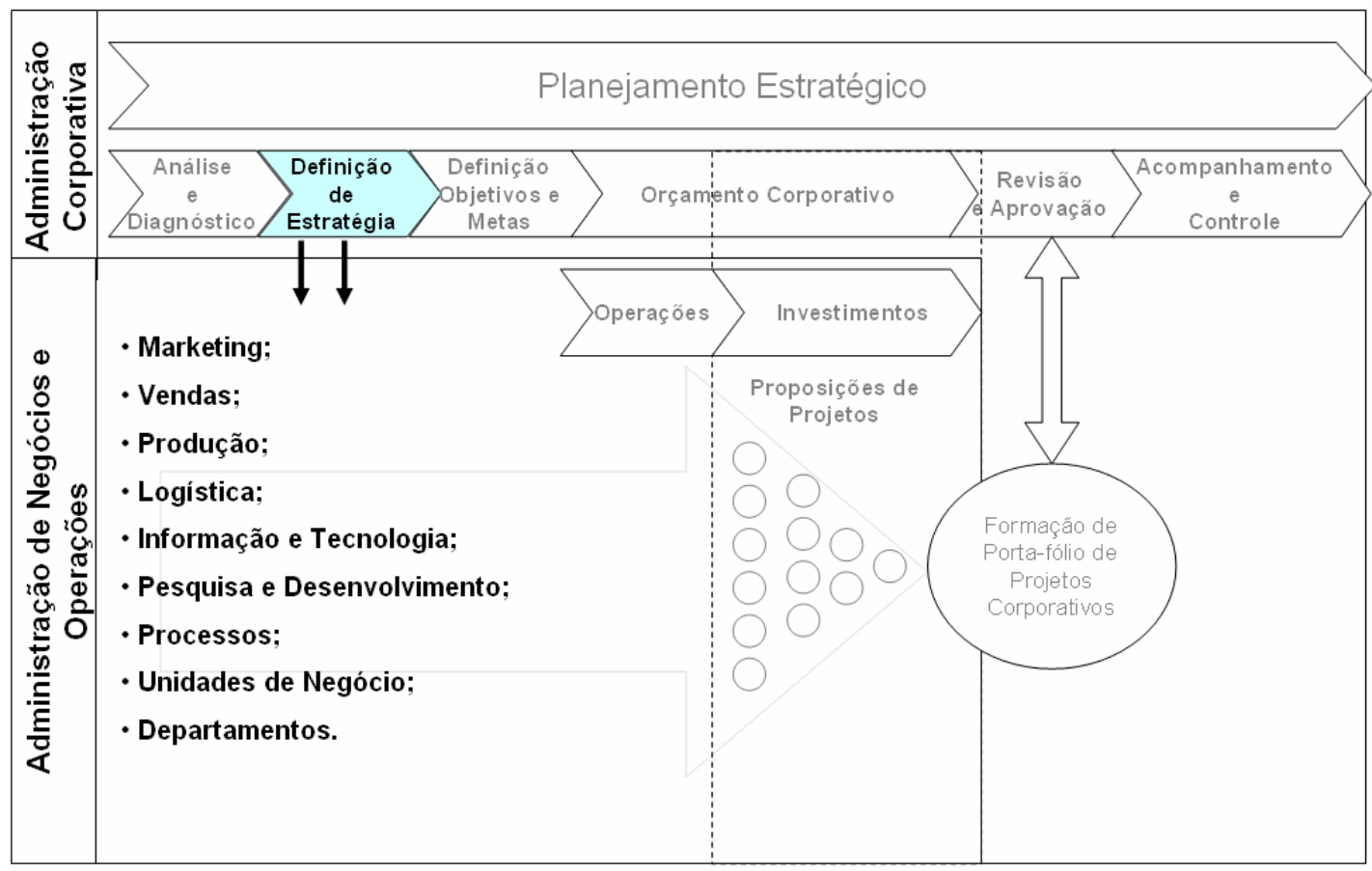

Figura 5 - Planejamento estratégico - Fase II-.Missão da empresa / definição de estratégia. A coluna da esquerda indica as hierarquias envolvidas em cada um dos processos indicados pelas setas largas. As setas menores indicam o fluxo de informação que permeia entre os envolvidos no processo. Neste momento deve ser estabelecida a razão de ser da empresa, bem como seu posicionamento estratégico.

- FASE III: Instrumentos prescritivos e quantitativos - Neste momento, estabelece-se o "como" chegar à situação desejada. Para tanto, dois instrumentos são desenvolvidos:

- Instrumentos prescritivos: proporcionam a explicitação do que deve ser feito efetivamente pela empresa para 0 atendimento da estratégia estabelecida. Podem ser divididos nas seguintes etapas:

* Estabelecimento de objetivos, desafios e metas;

* Estabelecimento de estratégias e políticas funcionais;

* Estabelecimento dos projetos e planos de ação.

- Instrumentos quantitativos: Consistem nas projeções econômico-financeiras do planejamento orçamentário, devidamente associadas à estrutura organizacional da empresa, necessárias ao desenvolvimento dos planos de ação, projetos e atividades previstas. Nesta etapa deve-se 
analisar quais são os recursos necessários e quais as expectativas de retorno para atingir os objetivos e metas da empresa.

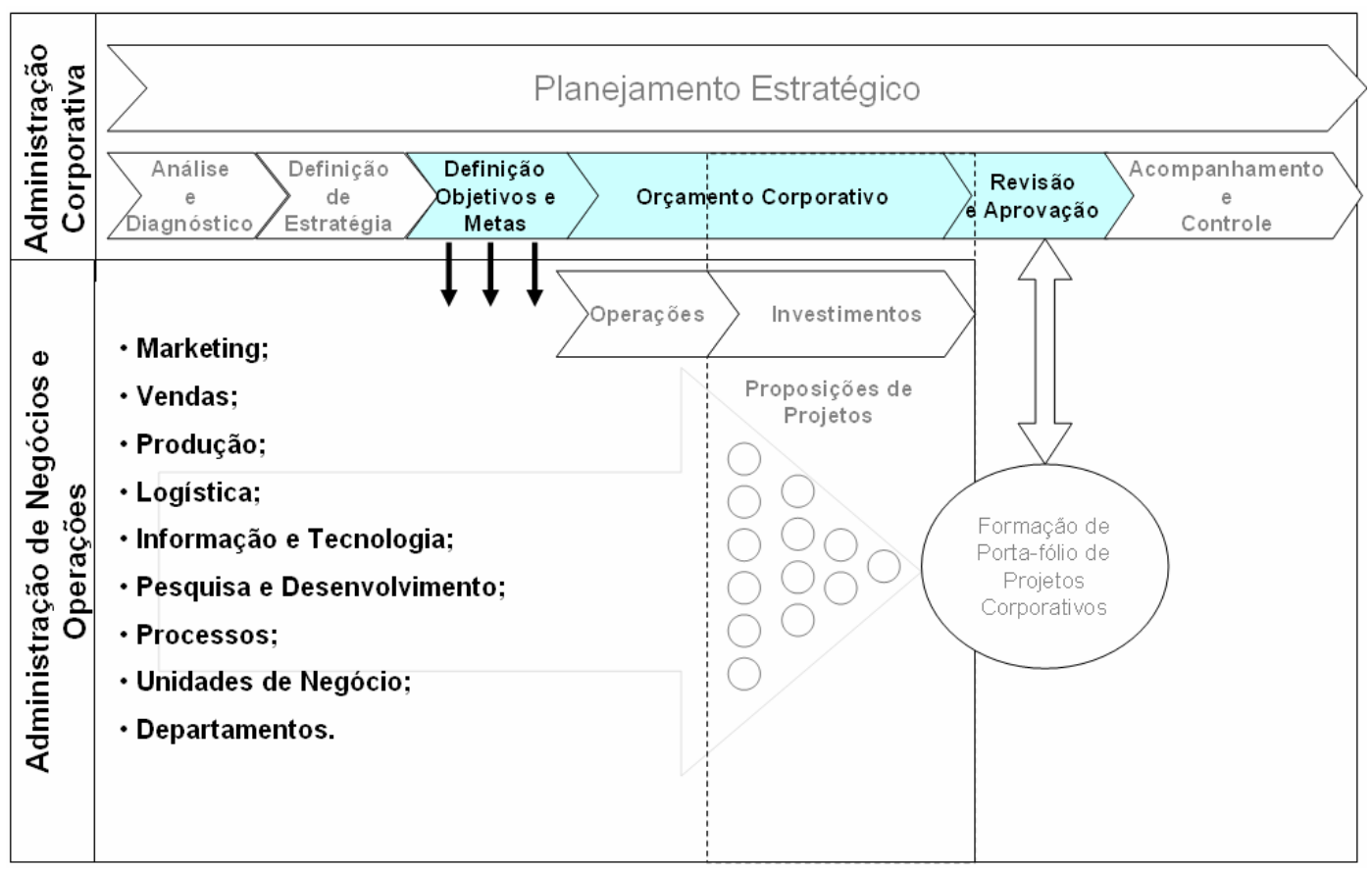

Figura 6 - Planejamento estratégico - Fase III-.Instrumentos prescritivos e quantitativos. A coluna da esquerda indica as hierarquias envolvidas em cada um dos processos indicados pelas setas largas. As setas menores indicam o fluxo de informação que permeia entre os envolvidos no processo. Neste momento estabelece-se o "como" chegar à situação desejada. Definem-se os objetivos e metas que deverão orientar o desenvolvimento dos planos de ação na forma de orçamentos corporativos. Após a submissão dos orçamentos, revisões do plano são efetuadas e o orçamento é aprovado.

- FASE IV: Controle e avaliação - Nesta fase, acompanha-se o desempenho dos planos de ações previstos pelo planejamento estratégico. Essa fase, em um sentido amplo, envolve processos de:

- Avaliação de desempenho;

- Comparação do desempenho real com os estabelecidos;

- Análise de desvios;

- Tomada de ações corretivas;

- Acompanhamento da eficiência das ações corretivas;

- Adição de informações ao processo de planejamento para desenvolvimento de ciclos futuros das atividades administrativas. 


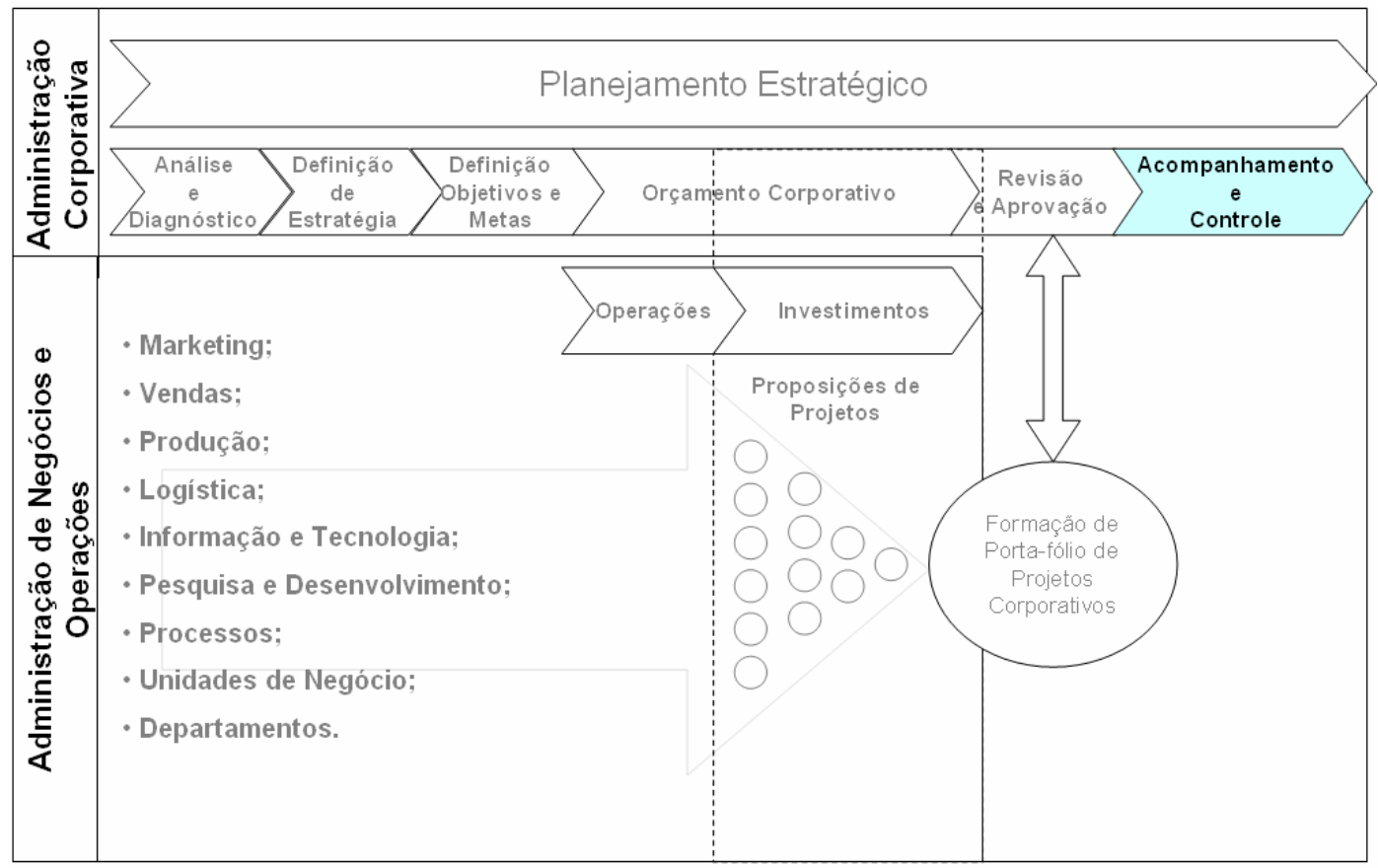

Figura 7 - Planejamento estratégico - Fase IV-.Controle e avaliação. A coluna da esquerda indica as hierarquias envolvidas em cada um dos processos indicados pelas setas largas. As setas menores indicam o fluxo de informação que permeia entre os envolvidos no processo. Nesta fase, acompanhase o desempenho dos planos de ações previstos pelo planejamento estratégico.

Uma vez que o planejamento estratégico tenha definido os objetivos, passa-se à elaboração dos planos de ação, que são manifestados na forma de orçamentos. Desta forma, o orçamento corporativo insere-se no planejamento estratégico, acima descrito, na fase III. Cada área da organização reflete sobre seu papel dentro da empresa, estabelecendo objetivos secundários e ações, a fim de que se possa alcançar as metas e objetivos estabelecidos pelo planejamento estratégico (TAVARES, 2000).

\subsubsection{Planejamento orçamentário}

O orçamento corporativo estima e determina a melhor relação entre resultados e despesas para atender às necessidades, características e objetivos da empresa no período esperado, envolvendo todas as áreas da empresa com necessidades de alocação de algum tipo de recurso financeiro (TAVARES, 2000; RASMUSSEN et al., 2003). 
Como um elemento de ação efetiva, o orçamento corporativo é considerado um dos mais importantes componentes do planejamento estratégico de uma organização. Por outro lado, o processo orçamentário é uma atividade complexa e conturbada, já que envolve diversas áreas e pontos de vistas. Nem sempre a linguagem utilizada por cada uma delas está alinhada ou padronizada. Trata-se também de um exercício quase sempre solitário, uma vez que freqüentemente não ocorre nenhuma ajuda ou orientação de uma gerência superior ou de quaisquer outros departamentos que possuam envolvimento ou dependências no processo. Outro aspecto importante é o fato de que orçamentos são baseados em dados contábeis e expressos em termos financeiros. Muitos gerentes não possuem conhecimento ou qualquer treinamento formal em contabilidade e sentem dificuldades no entendimento dos requisitos contábeis necessários à preparação do orçamento. Aliado a esse contexto, orçamentos em si são planos de riscos, pois estabelecem metas a partir de premissas que possuem componentes de incertezas (MOORE, 1999; LUNKES, 2003; RASMUSSEN et al., 2003; LORANGE, 1982).

De uma forma simples e geral um orçamento é formado por dois componentes básicos (MOORE, 1999):

Componente operacional - Este componente reflete despesas e custos operacionais, de produção e da administração. Estão também inclusas as receitas previstas oriundas de vendas e ganhos financeiros. Normalmente esta parte do orçamento é iniciada pelas metas de previsões de receitas em função das vendas. Uma vez estabelecidas as perspectivas de vendas, passa-se a aferir o esforço de produção dos bens e serviços demandados pelas vendas, estimando-se, respectivamente, os custos e despesas de produção e administração.

Componente de investimentos - Este componente reflete os aportes financeiros em investimentos da empresa. Nem sempre a atual conjuntura financeira, de negócios ou de infra-estrutura da organização possui capacidade de atingir as metas e objetivos determinados no planejamento estratégico. Ocorrem ainda situações em que a organização precisa inovar na forma de novos produtos e serviços. 
Nessas circunstâncias, faz-se necessária a implementação de iniciativas na forma de projetos. Em síntese, as unidades de negócio, áreas e departamentos, percebendo alguma limitação, possibilidades de exploração de oportunidades, necessidades de melhorias e de redução de despesas, ou ainda necessidades de novos produtos ou serviços, definem e orçam projetos.

Esses componentes, ilustrados na figura 8, são estimados para períodos anuais, em bases mensais, departamento por departamento, unidade por unidade de negócio, sendo finalmente simulado e consolidado um demonstrativo de resultados e um fluxo de caixa. De posse dessas informações, a organização pode aferir o retorno financeiro do período e avaliar se as metas de negócio serão alcançadas.

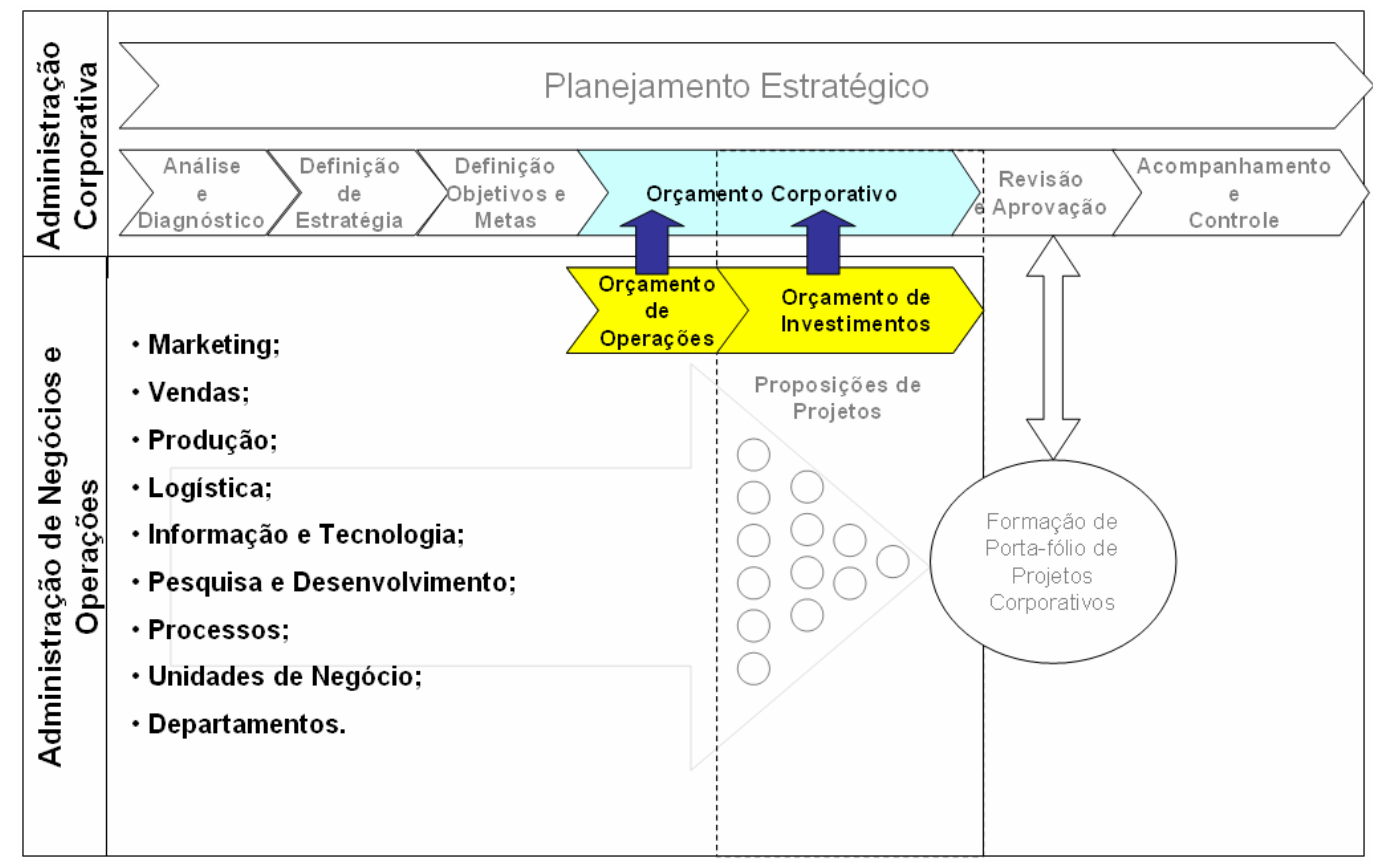

Figura 8 - Planejamento estratégico - Componentes orçamentárias. A coluna da esquerda indica as hierarquias envolvidas em cada um dos processos indicados pelas setas largas. As setas menores indicam o fluxo de informação que permeia entre os envolvidos no processo.Em destaque os componentes de um orçamento corporativo: Orçamento de operações e de investimentos.

Normalmente um ciclo de revisões é efetuado repetidas vezes, sofrendo ajustes e adequações até que resultado financeiro seja factível e atenda as exigências de retorno financeiro dos sócios ou acionistas. Uma vez que se obtenha um resultado satisfatório e consensual, o orçamento é finalmente publicado. 


\subsubsection{Orçamento de investimento}

O gerenciamento de investimentos é fundamental para o desenvolvimento e atendimento das metas estabelecidas no planejamento estratégico. As empresas que querem permanecer competitivas necessariamente terão de investir montantes cada vez maiores de recursos, sem qualquer certeza de colher resultados positivos. Além deste aspecto, as necessidades e cenários mudam a todo o momento e, portanto, fica evidente que as margens para erros se reduzem, principalmente quando se tratam de investimentos de longo prazo (CLELAND, 1999; LUNKES, 2003).

O componente de investimentos de um plano orçamentário refere-se às despesas com aquisições de ativos, bens de capital, construções, modificações e transformações que tenham caráter de melhoria, reposição de capacidade produtiva ou expansão de negócio. Relaciona despesas com aquisições e implementações de infra-estrutura de tecnologia, softwares, desenvolvimento de novos produtos e serviços, bem como em melhorias em processos para aumento de produtividade (SANVICENTE e SANTOS, 2000; RASMUSSEN et al., 2003).

É importante que este componente do orçamento seja elaborado de forma criteriosa, já que as decisões geralmente são irreversíveis e requerem um compromisso de recursos financeiros consideráveis. A forma de se operacionalizar os investimentos de capital de uma organização, em geral, é feita por projetos. A administração dos investimentos por projetos justifica-se por quatro razões (KERZNER, 2001(a), 2004; CLELAND, 1999; LUNKES, 2003):

- Necessidade de abordagem sistemática em investimentos;

- Integração entre a abordagem estratégica e operacional;

- Os recursos limitados disponíveis em uma organização;

- Investimentos cada vez mais dispendiosos e de riscos.

A geração de propostas de projetos ocorre pelas manifestações das áreas de negócio diante de suas percepções de riscos e oportunidades. Em geral, as idéias 
visam melhorias na produtividade, qualidade, novos produtos ou novas linhas de negócio, que serão implementadas através de projetos desde que aprovados e incluídos em um orçamento corporativo. A figura 9 ilustra o processo de geração de propostas dentro do planejamento estratégico.

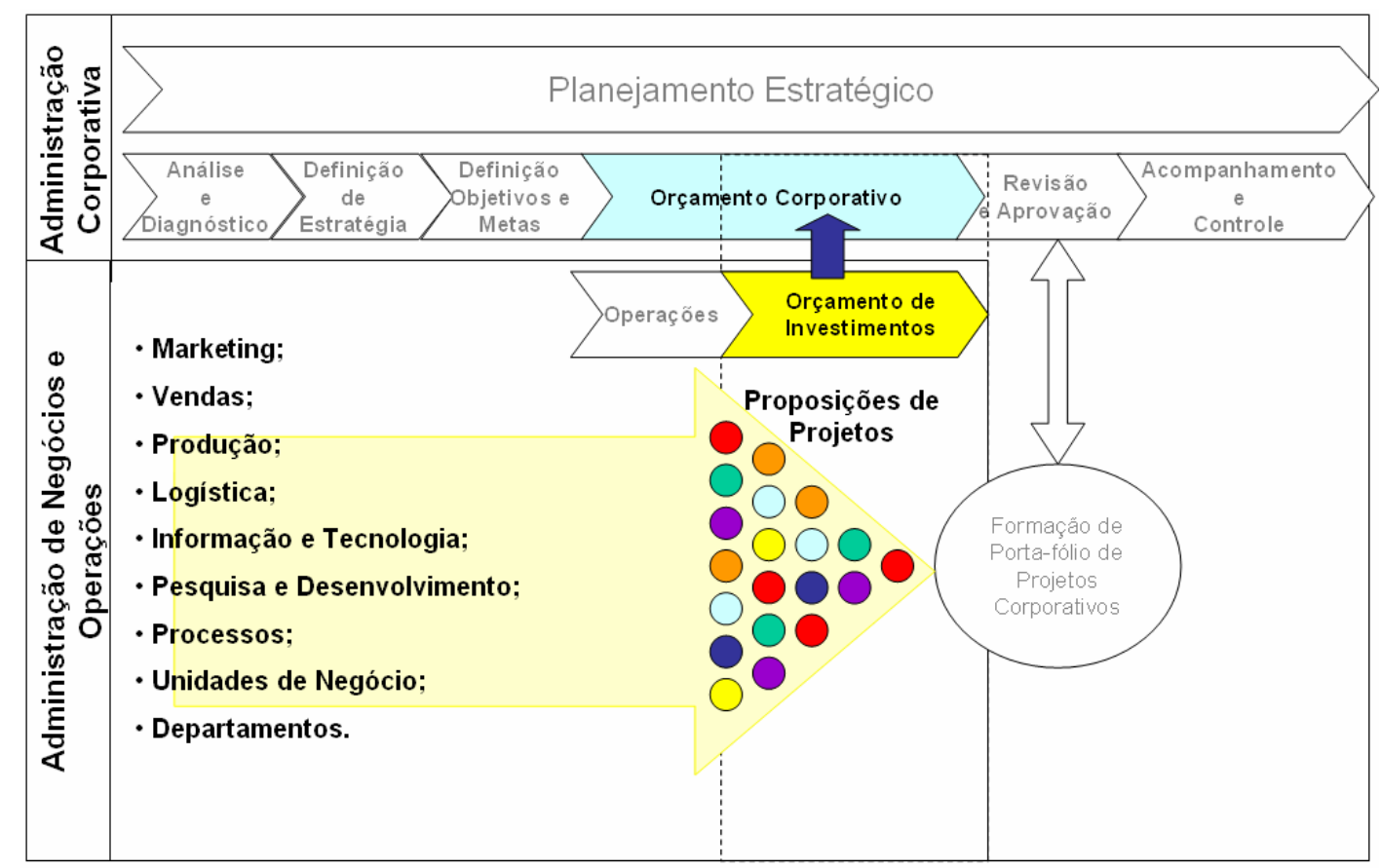

Figura 9 - Planejamento estratégico - processo de geração de propostas à projetos. A coluna da esquerda indica as hierarquias envolvidas em cada um dos processos indicados pelas setas largas. As setas menores indicam o fluxo de informação que permeia entre os envolvidos no processo. Os círculos coloridos representam as proposições de projetos a serem orçadas e aprovadas. A geração de propostas de projetos ocorre, em geral pelas manifestações das áreas de negócio diante de suas percepções de riscos e oportunidades, representadas à esquerda na figura. Em geral, as idéias visam melhorias na produtividade, qualidade, novos produtos ou novas linhas de negócio, que serão implementados através de projetos desde que aprovados e incluídos em um orçamento corporativo.

Nestes termos, os executivos responsáveis pelo processo de aprovação dos investimentos necessitarão de informações detalhadas a respeito das propostas de projetos, a fim de que possa ser feito uma tomada de decisão. É recomendável que as seguintes informações estejam disponíveis (RASMUSSEN et al., 2003; LUNKES, 2003):

- Descrição do Projeto;

- Objetivos e Metas;

- Justificativa e avaliação do projeto; 
- Desembolsos financeiros previsto para inclusão no orçamento corporativo;

- Cronograma de implementação previsto;

- Economias, benefícios e ou receitas esperadas.

A definição dos investimentos em um processo orçamentário deve ocorrer através de um processo estruturado, baseado em etapas a serem observadas durante a avaliação das propostas de projetos (COPELAND, 2000). Esta abordagem pode ser cumprida pelo uso de processos formais de gestão de porta-fólio de projetos (CRAWFORD, 2002; KERZNER, 2004, 2001(b); KENDALL e ROLLINS, 2003; CLELAND, 1999). 


\subsection{Gestão de porta-fólio de projetos}

O gerenciamento do capital alocado para investimentos em projetos de uma organização é essencial para se garantir o sucesso de uma estratégia competitiva e os resultados financeiros de uma organização. O uso sistemático de ferramentas de avaliação, processos disciplinados e boas práticas podem ajudar as organizações a definirem o melhor conjunto de investimentos a serem considerados (KOYAMA; TASSEL, 1998; CLELAND, 1999).

Um dos grandes problemas na definição de uma carteira de projetos reside no fato de que os tomadores de decisão, freqüentemente, possuem pouca informação para que se possam avaliar as propostas candidatas à formação de um porta-fólio. Incertezas, tais como o custo final do projeto e a percepção de seu valor perante a estratégia de empresa e o mercado, são grandes fontes de obscuridade que permeiam as probabilidades de sucesso de um projeto (KERZNER, 2004).

A falta de um conjunto mínimo de informações leva comumente a uma outra dificuldade: a falta de uma abordagem sistemática para a avaliação e seleção de projetos. Critérios de consenso e métodos para avaliação são essenciais para se tomar uma decisão. Embora as organizações busquem estabelecer objetivos e metas em seus planos estratégicos, elas normalmente não os detalham suficientemente de forma a permitir o uso de critérios específicos (KERZNER, 2001(b), 2004).

Destas considerações, firma-se a necessidade de estabelecer-se um modelo de construção e gestão de uma carteira de projetos dentro de uma organização, com objetivos de garantir-se que os investimentos de uma empresa estão sendo alocados em projetos que fazem sentido e de forma racional. Uma das formas de encaminhar-se essas questões é através da gestão de porta-fólio de projetos.

O conceito de construir e gerenciar um porta-fólio de projetos corporativos surgiu no final dos anos 50 e evoluiu ao longo dos anos 70 para se tornar uma ferramenta de planejamento consolidada. Embora as ferramentas e as formas de gestão de porta- 
fólio de projetos tenham mudado ao longo do tempo, a necessidade básica continua a mesma - empresas devem alocar um conjunto limitado de recursos em projetos, de forma a balancear riscos e retorno, garantindo alinhamento com a estratégia corporativa. Nos anos 80 e 90, as empresas estenderam o uso da gestão de portafólio para usos tais como seleção de novos produtos e na alocação de recursos em processos de pesquisa e desenvolvimento. (DICKINSON; THORNTON; GRAVES, 2001).

Em princípio, a gestão de porta-fólio deve satisfazer os seguintes objetivos (COOPER, 1997 apud DICKINSON; THORNTON; GRAVES, 2001):

- Maximizar o valor do Porta-fólio;

- Prover um Balanço de riscos;

- Suportar a estratégia da organização.

Outros autores identificam que a gestão de porta-fólio de projetos possui um escopo amplo e deve atender vários compromissos (KERZNER, 2004, KENDALL; ROLLINS, 2003):

- Determinar um conjunto de projetos viáveis que são capazes de atender os objetivos da organização;

- Balancear o porta-fólio para garantir que objetivos de curto, médio e longo prazos, risco e retorno sejam atendidos;

- Otimizar recursos humanos e financeiros;

- Equilibrar objetivos e desafios envolvidos na implementação do porta-fólio;

- Monitorar o planejamento e execução dos projetos selecionados;

- Avaliar e melhorar o desempenho do porta-fólio de projetos;

- Avaliar as oportunidades emergentes contra a atual configuração de projetos no porta-fólio corporativo;

- Fornecer informações e recomendações para tomada de decisão. 
Muito embora as diversas ferramentas analíticas que direcionam um processo de gestão de porta-fólio de projetos estejam consolidadas e prontas para uso, um processo formal de gestão é essencial na seleção e determinação da melhor combinação de um conjunto de projetos, bem como no melhor nível do aporte de capital para a execução dos mesmos (DICKINSON; THORNTON; GRAVES, 2001).

A decisão de como alocar recursos em investimentos na forma de projetos é, em geral, caracterizada por um processo árduo e cheio de dificuldades. O volume de proposições, as diversas percepções de uma estratégia, bem como os interesses individuais de departamentos, unidades de negócio e gerências causam grandes interferências na definição de uma carteira de projetos coerente com os objetivos de uma organização (MOORE, 1999; RASMUSSEN et al., 2003).

O processo de gestão de porta-fólio de projetos inicia-se pela seleção de projetos que irão compor a carteira (CRAWFORD, 2002). No que diz respeito a gestão de porta-fólio, esta fase é a de principal interesse neste trabalho e seus conceitos serão explorados nas próximas seções.

\subsubsection{Técnicas de seleção de projetos}

A seleção de projetos é caracterizada por uma série de atividades que exigem um esforço considerável de tempo com a dedicação de recursos capacitados. A condução das atividades é geralmente acompanhada de dificuldades, principalmente de comunicação e análise. (MEREDITH; MANTEL, 2000; RASMUSSEM et al., 2003)

Em projetos de inovação, novos produtos, pesquisa e desenvolvimento, o processo de seleção de propostas é considerado um fator crítico, pois nesses casos, os investimentos possuem um nível de riscos muito maior, dada as incertezas de sucesso. O ciclo de desenvolvimento de um produto, desde etapas de identificação das oportunidades, desenvolvimento até a comercialização, demonstra que cada estágio é mais custoso que o precedente, dado os investimentos necessários tanto em recursos como em tempo. Esse ciclo, em geral, ocorre em seis estágios (KERZNER, 2002): 
1. Exploração - Busca de idéias de produtos para atingir os objetivos da companhia;

2. Análise preliminar - Uma rápida análise com objetivos de determinar quais idéias são pertinentes e merecem atenção para um estudo mais detalhado;

3. Análise de negócio - Trata-se da expansão da idéia através de uma análise dentro de premissas de negócio concretas, incluindo funcionalidades do produto, análise financeira, riscos, avaliação de mercado e um programa de desenvolvimento do produto;

4. Desenvolvimento - Construção do protótipo ou produto;

5. Teste - Experimentos técnicos e comerciais necessários para se avaliar o desempenho do novo produto;

6. Comercialização - Lançamento do produto em escala de produção para o mercado.

O volume de idéias identificado em uma fase de exploração tende a ser grande e com grande variedade de objetivos. Esta característica impõe um tratamento preliminar de filtro, evitando empenhar recursos humanos e financeiros em análises mais detalhadas e sofisticadas para propostas de pouca probabilidade de sucesso.

O Gráfico da figura 10 demonstra a curva de afunilamento esperado pelo descarte de proposta ao longo de uma análise preliminar e de negócios.

Um outro importante ponto a ser considerado é o volume de investimentos nas três últimas fases devido ao empenho, cada vez mais intenso, de capital e horas de desenvolvimento e testes.

O Gráfico da figura 11 representa a curva crescente de despesas e investimentos esperada ao longo de cada estágio no desenvolvimento de novos produtos. 
Número de proposições

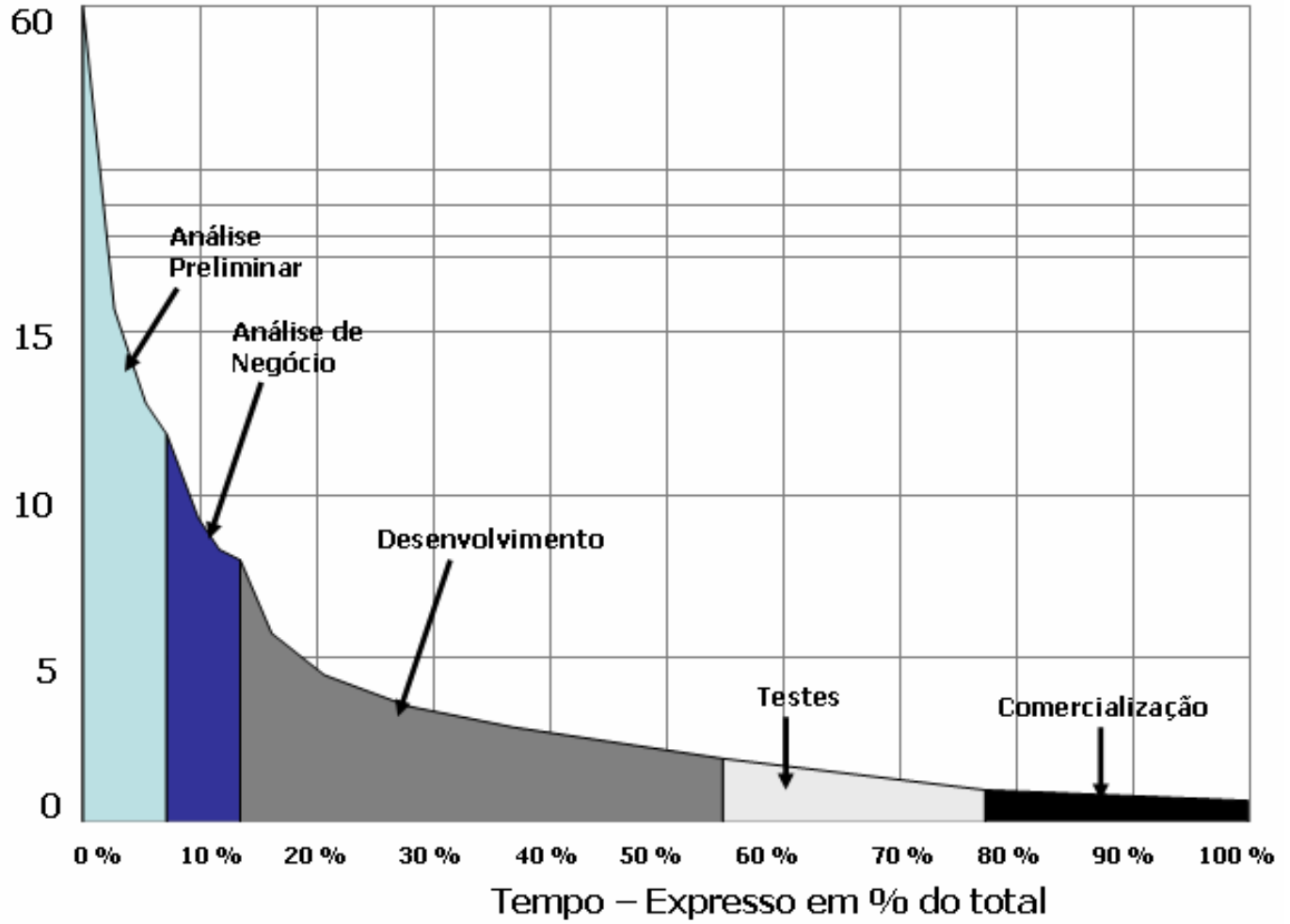

Figura 10 - Mortalidade de propostas para novos produtos / projetos. O volume de idéias/proposições caem ao longo das etapas principalmente pelo entendimento, qualificação e descarte de propostas com baixa probabilidade de sucesso ou infundadas.

(KERZNER, 2004, p. 252, tradução nossa)

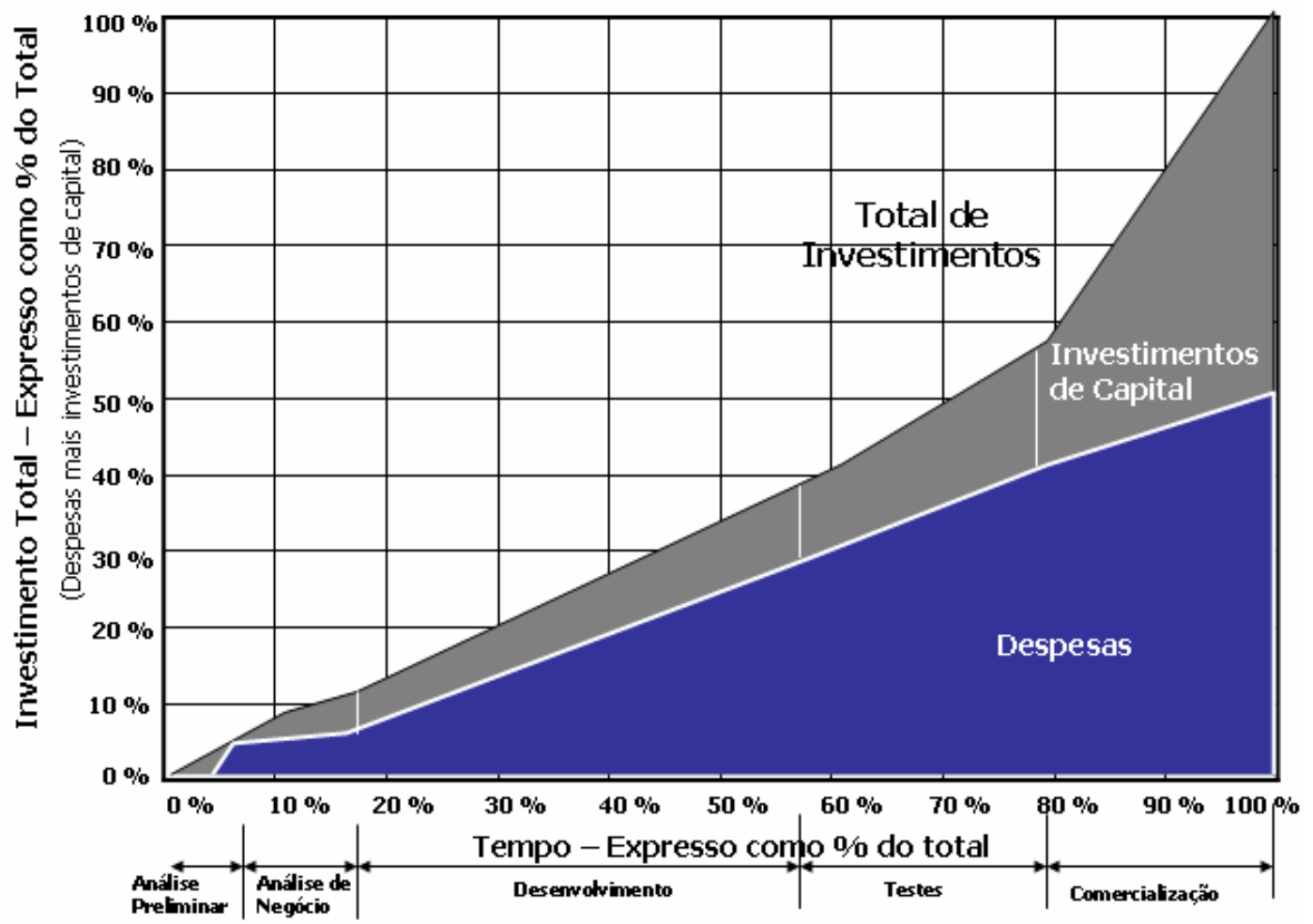

Figura 11 - Investimentos acumulados ao longo do tempo. O capital investido em uma idéia/proposição cresce a cada etapa, principalmente pelo investimento de tempo, recursos e ativos da organização. Fazse, portanto, necessário a correta seleção de proposições para que se evite perdas.

(KERZNER, 2004, p. 253, tradução nossa) 
Considerando-se esses aspectos, é muito recomendável que se execute as etapas de análise preliminar e de negócio de forma rigorosa, a fim de se eliminar idéias com potencial limitado antes de se manter continuidade nos investimentos necessários. A principal causa de insucessos em projetos, seja ele de qualquer caráter, deve-se a negligências no investimento de tempo na avaliação de proposições antes de se decidir pela aprovação de um projeto. (MEREDITH; MANTEL, 2000).

Independente dos tipos e objetivos dos projetos a serem considerados, um processo de seleção estruturado é, portanto, crucial na formação de um porta-fólio de projetos corporativo e deve estar apoiado nas seguintes etapas (KERZNER, 2001(a), 2004 ; MEREDITH; MANTEL, 2000; KOYAMA; TASSEL, 1998) :

- Análise preliminar;

- Análise de viabilidade e custo benefício;

- Priorização, através de critérios de qualificação;

- Balanceamento de riscos, objetivos e recursos.

\subsubsection{Análise preliminar}

A expansão e detalhamento dos conceitos que permeiam cada proposta podem ser dispendiosos, tanto em termos de custos como em tempo. Um processo preliminar de avaliação é recomendável para evitar que horas de recursos especializados sejam empregadas em propostas de baixa probabilidade de sucesso ou mesmo infundadas. Um processo de filtro baseado em um questionário pode ser utilizado para que se qualifique as proposições à projetos (CLELAND, 1999; KOYAMA; TASSEL, 1998 ; DICKINSON; THORNTON; GRAVES, 2001):

- Existe de fato uma necessidade real para este projeto?

- Quais benefícios e propósitos o projeto atende em termos das estratégias da organização?

- O projeto pode ser entregue dentro de um prazo que atenda as expectativas de retorno?

- Existem outras alternativas que atendam as necessidades verificadas? 


\subsubsection{Análise de viabilidade e custo-benefício}

Sob uma perspectiva financeira, a seleção de projetos é possível de empreender-se através de um simples processo de estudo de viabilidade seguido de uma análise de custo-benefício (KERZNER, 2001 (a)).

Um estudo de viabilidade tem como propósito avaliar se o projeto é viável tecnicamente, financeiramente e comercialmente. $O$ estudo também avalia o grau de dificuldade, riscos, bem como os requisitos de implementação.

Já a análise de custo-benefício requer uma abordagem mais extensa na medida em que exige um nível de informação que normalmente não está disponível ou apresenta um grau de incerteza muito grande nestes estágios de desenvolvimento.

As dificuldades residem inicialmente na determinação dos benefícios intrínsecos de um projeto, que podem estar classificados em duas classes (KERZNER, 2001 (a)):

- Tangíveis - Que podem ser quantificados em unidades monetárias, porém exibem um grau de incerteza que varia de acordo com o caráter da proposta;

- Intangíveis - Que exigem uma abordagem praticamente subjetiva, que em muitos casos precisa ser quantificada sob o risco de uma grande incerteza.

Um outro fator de dificuldade reside na determinação dos custos de uma proposição. A qualidade da informação gerada nesta análise será proporcional à disponibilidade de informações necessárias ao método, o tempo empenhado na produção da mesma, bem como da experiência dos profissionais envolvidos. 


\subsubsection{Priorização - critérios de qualificação}

Em geral, o número de proposições concorrentes é superior às capacidades financeiras e de recursos disponíveis em uma organização. A tomada de decisão deve também levar em consideração critérios comuns que permitam comparar e priorizar propostas de projetos.

A responsabilidade da definição de critérios de qualificação das propostas cabe a alta gerência de uma organização que deve apoiar-se em critérios que se baseiam nos objetivos e metas estabelecidas pela estratégia corporativa. Em geral, os critérios selecionados podem ser classificados como (KERZNER, 2001(a); MEREDITH; MANTEL, 2000):

- Subjetivos;

- Objetivos;

- Qualitativos;

- Quantitativos.

Os critérios, ainda que variem de acordo com o tipo dos projetos avaliados, devem ser estabelecidos de forma prévia para evitar decisões tendenciosas. Existem ainda questões que permeiam a interpretação do tipo de critério a ser utilizado em um processo de seleção. É importante que exista o devido entendimento das diferenças entre critérios subjetivos e objetivos, bem como qualitativos e quantitativos (MEREDITH; MANTEL, 2000 ):

- Critérios subjetivos versus objetivos - O primeiro faz referência a padrões estabelecidos internamente à organização, tal como a avaliação especializada de um grupo de executivos da empresa. $\mathrm{O}$ segundo faz referência a padrões de entendimento universal, ou seja, externos à organização;

- Critérios qualitativos versus quantitativos - Não deve ser confundido com a relação de critérios não-numéricos e numéricos, respectivamente. Ambos tratam-se de grandezas numericamente 
mensuráveis, porém a diferença reside no fato que podemos utilizar a lei de adição em critérios quantitativos de mesma dimensão.

O uso intensivo de critérios objetivos e quantitativos, muito comum nas análises financeiras de rentabilidade, também pode gerar decisões equivocadas. É recomendável também o uso simultâneo de critérios de avaliação não-numéricos e numéricos:

- Modelos não-numéricos: Neste método, as propostas sofrem avaliação e classificação através de critérios subjetivos tais como:

- Necessidade de criação de novos produtos;

- Necessidades operacionais da organização;

- Requisitos legais;

- Imagem corporativa;

- Aumento de competitividade.

- Modelos numéricos: Em geral, apresentam-se na forma de métricas financeiras de performance, que medem de forma objetiva a rentabilidade de uma proposição através de métodos tais como:

- Período de retorno (Payback period) - Indica o prazo para o qual os benefícios financeiros de um projeto passam a superar o investimento de sua aplicação;

- Fluxo de caixa descontado (NPV - Net present value) Considera o fluxo de caixa descontado por uma taxa percentual desejada para o retorno de um investimento. Neste método, tanto investimentos e despesas, como as receitas proporcionadas por um novo projeto são levadas a valor presente. Obtendo-se um resultado positivo, entendese que o projeto é financeiramente viável;

- Taxa interna de retorno (IRR - Internal rate of return) Determina a taxa de desconto para o qual os valores 
presentes líquidos de um fluxo de caixa iguala as receitas com os investimentos e despesas. Se a taxa de desconto determinada for igual ou superior a expectativa de retorno de investimento definida, o projeto demonstra ser financeiramente viável.

Métodos numéricos de pontuação (Scoring Models) também podem ser utilizados para suprir as deficiências de análises financeiras que não levam em consideração aspectos qualitativos que devem ser avaliados em conjunto para uma tomada de decisão. Um conjunto de fatores qualitativos relevantes à análise é selecionado e os projetos são pontuados em relação ao nível de aderência que eles proporcionam em cada um desses critérios. Cada nível de aderência recebe uma nota de avaliação, podendo-se também fazer uso de ponderações através de pesos específicos para cada fator em julgamento.

Em geral, os valores obtidos pelas avaliações em métodos numéricos, qualitativos e quantitativos, são tabulados em planilhas que estabelecem pesos para cada um dos critérios de avaliação. Os pesos devem estar orientados à relevância que eles representam dentro de uma estratégia. A pontuação final para um projeto é obtida pela soma dos resultados de cada critério, considerado os pesos atribuídos. A ordenação da planilha, pela pontuação final de cada projeto estabelece a priorização.

A tabela 5 apresenta um exemplo de planilha para pontuação de um projeto diante de vários critérios qualitativos e quantitativos (CLELAND, 1999). Este modelo apresenta diversos critérios, entre subjetivos e objetivos, bem como qualitativos e quantitativos, que podem ser pontuados em uma escala que varia entre "Muito Bom" até "Muito Insatisfatório". Pode-se também estabelecer uma probabilidade a ser considerada entre cada uma destas escalas, dentro de um mesmo critério. Um peso estabelece a relevância de cada um dos critérios a serem considerados. A pontuação total deve ser considerada em uma planilha secundária para comparar os resultados entre vários projetos submetidos ao mesmo processo. 


\begin{tabular}{|c|c|c|c|c|c|c|c|c|c|}
\hline $\begin{array}{c}\text { Critérios de avaliação de } \\
\text { projetos/programas }\end{array}$ & & $\begin{array}{l}\text { Peso dos } \\
\text { Critérios }\end{array}$ & $\begin{array}{l}\text { Muito Bom } \\
\text { (8) }\end{array}$ & $\begin{array}{c}\text { Bom } \\
(6)\end{array}$ & $\begin{array}{c}\text { Razoável } \\
\text { (4) }\end{array}$ & $\begin{array}{c}\text { Insatisfatório } \\
\text { (2) }\end{array}$ & $\begin{array}{c}\text { Muito } \\
\text { Instisfatório } \\
(0)\end{array}$ & Pontuação & $\begin{array}{c}\text { Pontuaçäo } \\
\text { Final } \\
\text { (Ponderada) }\end{array}$ \\
\hline \multirow[t]{2}{*}{ Aderéncia com a missão } & Produto & 10 & 1,0 & - & - & - & - & 8,0 & 80,0 \\
\hline & Mercado & 10 & 1,0 & - & - & - & - & 8,0 & 80,0 \\
\hline \multirow[t]{3}{*}{ Consistencia com objetivos } & ROI & 10 & 0,2 & 0,6 & 0,2 & - & - & 6,0 & 60,0 \\
\hline & Dividendos & 5 & - & 0,2 & 0,6 & 0,2 & - & 4,0 & 20,0 \\
\hline & Im agem & 5 & - & - & 0,8 & 0,2 & - & 3,6 & 18,0 \\
\hline \multirow[t]{3}{*}{ Consistência com a estratégia } & Estágio 1 & 10 & & & & & 1,0 & 0,0 & 0,0 \\
\hline & E tágio 2 & 7 & 1,0 & - & - & - & & 8,0 & 56,0 \\
\hline & E ságio 3 & 3 & - & - & - & - & 1,0 & 0,0 & 0,0 \\
\hline \multirow[t]{4}{*}{ Contribuição para os objetivos } & Objetivo A & 8 & & & & & 1,0 & 0,0 & 0,0 \\
\hline & Objetivo $\mathrm{B}$ & 6 & 0,8 & 0,2 & - & - & - & 7,6 & 45,6 \\
\hline & Objetivo $\mathrm{C}$ & 4 & & 0,8 & 0,2 & - & - & 5,6 & 22,4 \\
\hline & Objetivo D & 2 & & & & & & 0,0 & 0,0 \\
\hline A derência com pontos fortes da organização & & 10 & - & - & - & 0,8 & 0,2 & 1,6 & 16,0 \\
\hline A derência com pontos fracos da organização & & 10 & - & - & - & 0,2 & 0,8 & 0,4 & 4,0 \\
\hline Nivel de vantagem para a organização & & 10 & 0,7 & 0,3 & - & - & - & 7,4 & 74,0 \\
\hline Nível de consistencia interna & & 10 & 1,0 & - & - & - & - & 8,0 & 80,0 \\
\hline Nivel de aceitação de risco & & 10 & - & - & & 0,7 & 0,3 & 1,4 & 14,0 \\
\hline Consistencia com as políticas internas & & 10 & - & - & 1,0 & - & - & 4,0 & 40,0 \\
\hline
\end{tabular}

Tabela 5 - Exemplo de planilha de pontuação para avaliação de propostas de projetos. Este modelo apresenta diversos critérios, entre subjetivos e objetivos, bem como qualitativos e quantitativos, que podem ser pontuados em uma escala que varia entre "Muito Bom" até "Muito Insatisfatório". Pode-se também estabelecer uma probabilidade a ser considerada entre cada uma destas escalas, dentro de um mesmo critério. Um peso estabelece a relevância de cada um dos critérios a serem considerados. A pontuação total deve ser considerada em uma planilha secundária para comparar os resultados entre vários projetos submetidos ao mesmo processo.

(CLELAND, 1999, p. 101, tradução nossa).

\subsubsection{Balanceamento de riscos, objetivos e recursos.}

Em geral, as organizações possuem uma pré-disposição a assumir riscos até um determinado nível e este varia de acordo com os tipos e objetivos dos projetos a serem avaliados. A seleção de projetos também deve levar em consideração o balanceamento de riscos desejado, a adequada distribuição das propostas a serem aprovadas em termos de projetos de inovação, melhorias em processos e expansão de negócios. O nível de exposição de cada uma das propostas deve ser qualificado em termos de riscos de negócio, financeiros e técnicos.

Em determinados seguimentos, pode-se decidir por assumir riscos altos na implementação de um projeto se a proposta oferecer uma possibilidade de grande retorno ou ainda uma nova perspectiva para a organização. Em situações em que existe uma intolerância a riscos, tais como projetos de manutenção ou outros vinculados a grandes aporte de capital, a empresa pode optar por descartar uma proposta ou solicitar uma reavaliação para que se encontrem mecanismos de redução de riscos. 
Outro importante elemento a ser levado em consideração na construção de um porta-fólio de projetos é a definição da capacidade de atendimento da organização na implementação daquele. Deve ser levado em consideração o capital humano estratégico, interno e externo, disponível para condução destes projetos (KENDALL; ROLLINS, 2003):

Como capital humano estratégico, entende-se aqueles indivíduos cujo valor para a organização não se limita a conhecimentos técnicos e administrativos que podem ser supridos por uma adequada seleção de pessoas no mercado. Tratam-se sim, de indivíduos que possuem um conhecimento oriundo da vivência dentro da organização, tais como de negócios, administrativos e de cultura que não podem ser desenvolvidos no curto prazo por novas contratações.

A abordagem de balanceamento de recursos humanos deve levar em consideração os seguintes elementos (KERZNER, 2004):

- A qualidade dos recursos humanos disponíveis na organização para o endereçamento dos projetos;

- A necessidade de cada um dos projetos no que diz respeito a competências consideradas fundamentais, tanto técnicas como administrativas;

- A demanda por tipos de recursos chave em cada uma das fases previstas, em cada um dos projetos.

- O volume de trabalho a ser considerado em cada uma das fases, em cada uma das competências chave a serem consideradas.

\subsubsection{O processo de seleção de projetos}

Todas as técnicas relacionadas às atividades de seleção de projetos devem estar estruturadas em um conjunto de etapas formais que garantam o direcionamento dos processos de definição do porta-fólio de forma sistemática, racional e organizada. Recomenda-se estabelecer uma coordenação para o processo, definindo os 
requisitos e padrões de documentações a serem atendidos em cada uma das etapas, bem como a responsabilidades de cada um dos envolvidos no processo (CRAWFORD, 2002; KERZNER, 2001(a)(b), 2004; KENDALL; ROLLINS, 2003; RASMUSSEN et al., 2003).

Por outro lado, não existe um modelo comum e universal de procedimentos a serem seguidos. Técnicas, bem como processos que apóiam a seleção de projetos devem variar de acordo com os tipos de negócio, maturidade e cultura de cada organização (KENDALL; ROLLINS, 2003). A partir da literatura pesquisada, um modelo geral de processo de formação de um porta-fólio de projetos pôde ser elaborado, considerando-se cinco importantes etapas identificadas:

1. Identificação de projetos - Consiste de uma etapa de exploração de oportunidades e propostas. O processo de identificação pode ser feito através de sessões de Brainstorming ${ }^{11}$, pesquisas de mercado, junto a clientes e fornecedores, bem como através das oportunidades verificadas internamente pelas unidades de negócio de uma organização. Todas as idéias, a despeito de seus méritos, devem ser documentadas;

2. Análise preliminar - As propostas identificadas são submetidas a uma análise qualitativa com objetivos de determinar-se quais são pertinentes e, portanto, um detalhamento em termos de viabilidade e custo benefício fazem-se necessários;

3. Análise de negócio - Sob a perspectiva financeira, a avaliação preliminar consiste essencialmente de um processo de duas etapas. Em primeiro lugar, a organização conduz um estudo de viabilidade para averiguar se o projeto pode ser feito. A segunda parte consiste no desenvolvimento de uma análise de custo-benefício para avaliar se o projeto deve ser feito.

4. Seleção estratégica de projetos - Neste passo é verificada a aderência do projeto com a estratégia corporativa, seguido de um

\footnotetext{
${ }^{11}$ O Brainstorming é uma técnica clássica para se desenvolver e extrair informações. Trata-se de um meio estimulado e facilitado de se dividir informações e idéias através de uma abordagem que não permite atitudes de críticas às proposições desenvolvidas pelos participantes dentro de um tópico proposto por um indivíduo atuando como facilitador (PRITCHARD, 2001).
} 
processo de priorização junto a outros projetos. Neste ponto, o envolvimento da alta-direção da organização é crítico devido ao impacto que os projetos podem ter no plano estratégico da companhia;

5. Análise de capacidade - Para a tomada de decisão em relação a quais projetos priorizados serão aprovados, a organização deve também levar em consideração a disponibilidade interna de recursos. Além dos recursos financeiros, recursos humanos também devem ser avaliados sob pena de aprovar-se um volume de projetos além da capacidade disponível ou ainda a projetos que demandam competências internas inexistentes.

A figura 12 ilustra a complementação do processo de planejamento estratégico e orçamentário, sob a perspectiva da abordagem proposta para seleção de projetos.

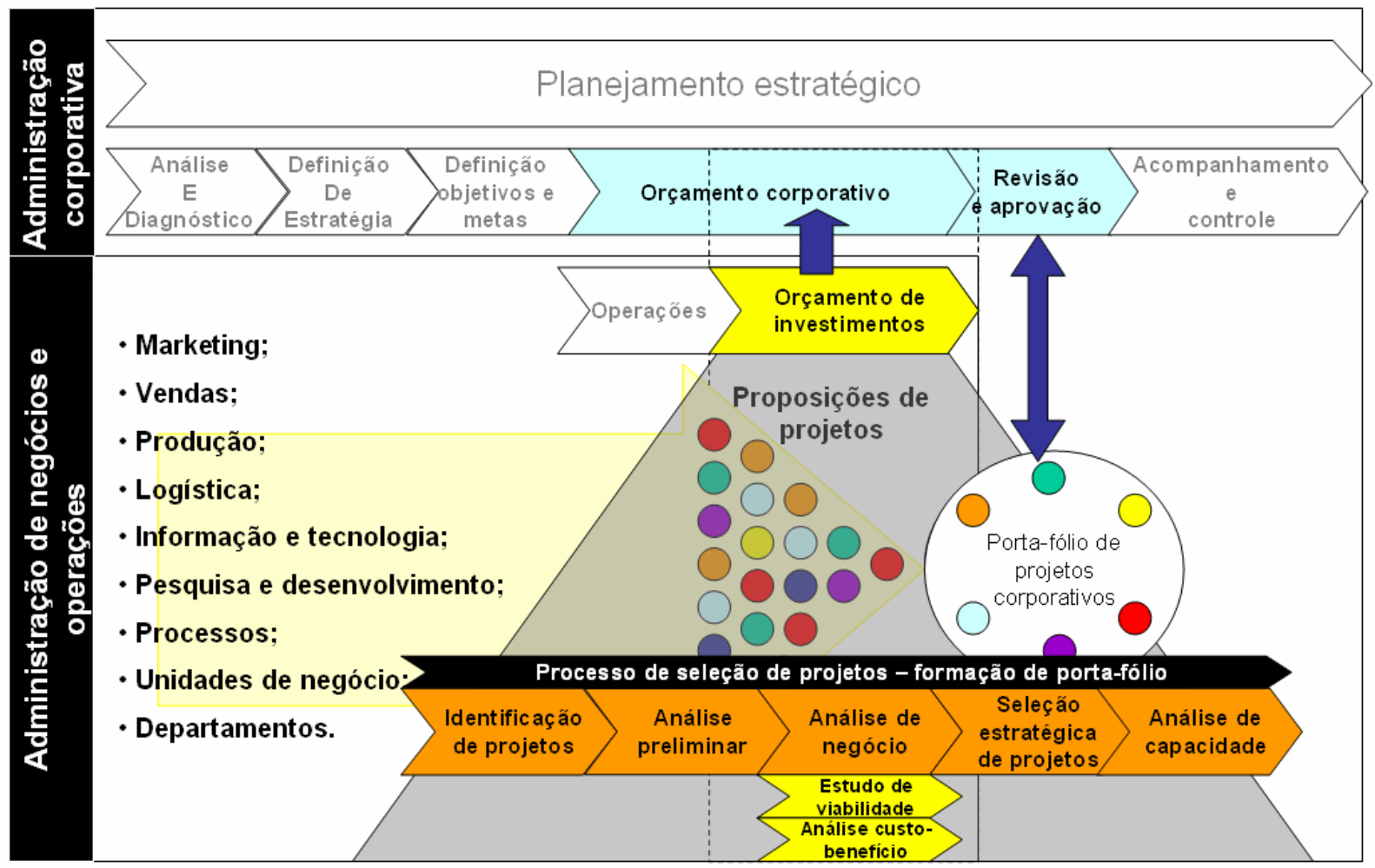

Figura 12 - Planejamento estratégico - processos de seleção de projetos. A coluna da esquerda indica as hierarquias envolvidas em cada um dos processos indicados pelas setas largas. As setas menores indicam o fluxo de informação que permeia entre os envolvidos no processo. Os círculos coloridos representam as proposições de projetos a serem orçadas e aprovadas. A geração de propostas de projetos ocorre, em geral pelas manifestações das áreas de negócio diante de suas percepções de riscos e oportunidades, representadas à esquerda na figura. Em destaque apresenta-se a incorporação do processo de seleção de projetos em cinco sub-processos qualificadores que apoiarão a tomada de decisão na formação de um porta-fólio de projetos, representado pelo circulo maior à direita. 
Dependendo do tamanho da organização, volume e tipos de projetos a serem tratados, a definição de uma da área responsável pelo processo, composta de recursos humanos com as competências administrativas e técnicas necessárias, é uma possibilidade que deve ser fortemente considerada.

Um ponto de concordância entre os vários autores pesquisados é que o processo como um todo não se trata de algo trivial e exige disciplina, formalidade e uma série de conhecimentos que se situam, principalmente, em disciplinas de áreas como finanças, administração, engenharia e projetos. Neste sentido, esses autores defendem que a condução dos processos de gestão de porta-fólio de projetos corporativos seja apoiada por estruturas especializadas orientadas por boas práticas na administração de projetos, tais como os escritórios de gerenciamento de projetos (CRAWFORD, 2002; KERZNER, 2004; KENDALL; ROLLINS, 2003; RAD; LEVIN, 2002; DINSMORE; GRAHAM; ENGLUND, 2003). 


\subsection{Escritórios de gerenciamento de projetos}

O conceito ou a própria existência de um escritório de gerenciamento de projetos não é novo. Entretanto, a utilização deste tipo de arranjo organizacional como uma extensão para o processo de planejamento estratégico das empresas é uma atribuição recente (KENDALL; ROLLINS, 2003; CRAWFORD, 2002; RAD; LEVIN, 2002).

A forma como conhecemos os escritórios de gerenciamento de projetos de hoje é resultado de uma evolução que parte da crescente necessidade de se implementar projetos. A intensa participação de projetos dentro das atividades das organizações, a partir da segunda metade do século XX, levou a uma necessidade de desenvolvimento de novas habilidades específicas da administração de projetos, principalmente pelas dificuldades observadas e as estatísticas que apontam um grande volume em perdas de ativos corporativos em projetos fracassados (DINSMORE; GRAHAM; ENGLUND, 2003). Com o crescente volume de demandas por projetos a serem implementados, as organizações passam a também experimentar um aumento substancial dos conflitos internos.

O que se verifica é que boa parte dos freqüentes insucessos registrados na condução e entrega de projetos é devido ao despreparo e constantes conflitos entre executivos e gestores de projetos diante da disponibilidade de recursos, priorizações e dos prazos a serem atingidos. Este comportamento é derivado do fato que projetos surgem marginalmente às outras atividades da organização e possuem data marcada para encerramento. Enquanto as atividades perenes da organização possuem recursos financeiros e humanos pré-estabelecidos, os projetos necessitam de um planejamento e conciliação adicional de recursos, que irão competir com as demais atividades operacionais dentro de uma restrição de custos e prazos.

Os benefícios do uso de técnicas administrativas orientadas a gestão de projetos, que antes eram vistas como aplicáveis somente para indústrias tais como a aeroespacial, defesa e construção civil, passaram a ser adotadas por uma variedade de outros tipos de cenários de negócios. Com a proliferação desta nova 
mentalidade, derivou-se também a necessidade de incorporar-se estruturas formais e especializadas, com objetivos de conduzir de projetos, bem como em promover a formação de pessoal capacitado. Em geral, a literatura tem definido estas estruturas como escritórios de gerenciamento de projetos que doravante, estará sendo aqui referido pela sigla EGP.

Na década de 1950, o termo EGP foi empregado para nomear uma equipe dedicada ao gerenciamento de projetos específicos, geralmente de grande porte, proporcionando abordagens mais assertivas pela presença de uma equipe próxima ao cliente ou ao local de execução do projeto. Nesta época, as atividades de um escritório de projetos confundiam-se com as atividades do projeto propriamente dito e, portanto, assumiam competências bem diferentes das verificadas hoje (KERZNER, 2001(a), 2004).

De uma forma geral, O EGP tem sido descrito como um grupo de indivíduos autorizados a falar por um projeto (CLELAND, 1999). Com a nova demanda por modelos e profissionais em gestão de projetos, a figura do EGP volta à tona dentro das organizações, com novas atribuições (KERZNER, 2004):

- Padronização de Documentações;

- Padronização em processos de planejamento, execução e controle;

- Definição de responsabilidades e papéis;

- Delineamento de competências humanas;

- Identificação de padrões e boas práticas em gestão de projetos;

- Desenvolvimento de metodologia para a gestão de projetos;

- Treinamento de profissionais da área;

- Acompanhamento e orientação na carreira dos profissionais de gestão de projetos.

O EGP é visto hoje como uma forma de promover a cultura de gerência de projetos dentro de uma organização sob a perspectiva de melhoria de métodos e processos (FRAME; BLOCK, 1998) e influi diretamente na estratégia da empresa, na medida 
em que pode proporcionar serviços de monitoramento e controle de um porta-fólio de projetos. (RAD; LEVIN, 2002).

Diversos outros autores compartilham desta visão, acrescentando que o EGP é um centro de excelência em competências que provê foco organizacional nas atividades e processos de gestão de projetos e programas, sendo uma das suas principais missões a de suportar ativamente o planejamento estratégico das organizações (KERZNER, 2004; KENDALL; ROLLINS, 2003; TUCKER; AGOPIAN, 2006).

\subsubsection{Tipos de escritórios de gerenciamento de projetos}

O atual emprego dos EGPs, na maioria das organizações, tem se resumido ao direcionamento do dia-a-dia da gestão de projetos. Por outro lado, os EGPs, pela sua própria natureza e potencialidade podem e devem assumir um caráter mais estratégico dentro de uma empresa (KENDALL; ROLLINS, 2003).

O posicionamento de um EGP deve variar de acordo com o seu nível de maturidade, do arranjo organizacional em que ele se situa, bem como do tamanho e tipo de negócio de cada empresa (BARCAUIU; QUELHAS, 2004; CRAWFORD, 2002).

Kerzner indica que existem três principais modelos de operação para um EGP (KERZNER, 2004 ):

- Escritório de projetos funcional - É praticado isoladamente por uma área ou divisão funcional de uma organização, tal como encontrado em áreas de tecnologia da informação dentro das empresas. A maior responsabilidade deste tipo de configuração de escritório de projetos é a de gerenciar recursos limitados para o atendimento das demandas por projetos;

- Escritório de projetos orientado por grupo de clientes - É utilizado para uma gestão e comunicação mais efetiva junto aos clientes comuns de um ou vários projetos. Múltiplos escritórios deste tipo podem ser encontrados em uma mesma organização, convivendo 
simultaneamente e tendo também caráter temporário, na medida em que os projetos sejam concluídos;

- Escritório de projetos corporativo - Atua e permeia por toda a organização. Além de possuir um caráter funcional e operacional, possui também foco em aspectos estratégicos e corporativos.

O conceito de EGP é bastante versátil uma vez que pode ser aplicado isoladamente em unidades de negócio e departamentos ou possuir uma visibilidade que abrange toda a organização. As seguintes nomenclaturas para designar um EGP, de acordo com possíveis níveis, são observadas (DINSMORE; GRAHAM; ENGLUND, 2003):

- Nível 1 - Escritório de controle de projetos - Atua em um nível de projetos e é responsável basicamente pela emissão de relatórios do projeto e de acompanhamento de indicadores previamente estabelecidos;

- Nível 2 - Escritório de programas ou projetos ou centro de excelência em gestão de projetos - Atuando em um nível de departamento ou unidade de negócio, além das atribuições de um EGP de nível 1, atua como guardião e difusor de métodos e boas práticas na gestão de projetos.

- Nível 3 - Escritório estratégico de projetos - opera no nível corporativo, coordenando e definindo políticas e padrões para o gerenciamento de todos os projetos dentro da organização, gerenciando o porta-fólio corporativo e prestando auxílio aos EGPs de nível 1 e 2.

Uma outra abordagem, orientada pelo valor que um EGP pode proporcionar dentro da organização, estabelece três modelos possíveis (KENDALL; ROLLINS, 2003):

- Modelo de repositório - Atuando essencialmente como fonte de informações a respeito do estado e evolução dos projetos de uma organização, bem como difusor de metodologia e padrões dentro da disciplina de gestão de projetos; 
- Modelo de suporte e mentoração - Além das atribuições do modelo de repositório, atua com ênfase no desenvolvimento de competências, treinamento e consultoria nas disciplinas relacionadas a gestão de projetos;

- Modelo corporativo - Assume visibilidade corporativa, atuando como um centro de serviços compartilhados para atender todas as necessidades da organização no que concerne a gestão de projetos. Atua também na seleção de projetos, gestão de porta-fólio e de riscos, bem como na administração consolidada de todos os recursos envolvidos nos projetos de uma organização;

No que diz respeito a forma de atuação, as principais fontes de referência parecem concordar que existem três possibilidades de atuação de um EGP dentro de uma organização. Crawford propõe uma visão de três modelos básicos de EGPs a partir de seu posicionamento dentro da hierarquia organizacional. A figura 13 ilustra esta visão (CRAWFORD, 2002).

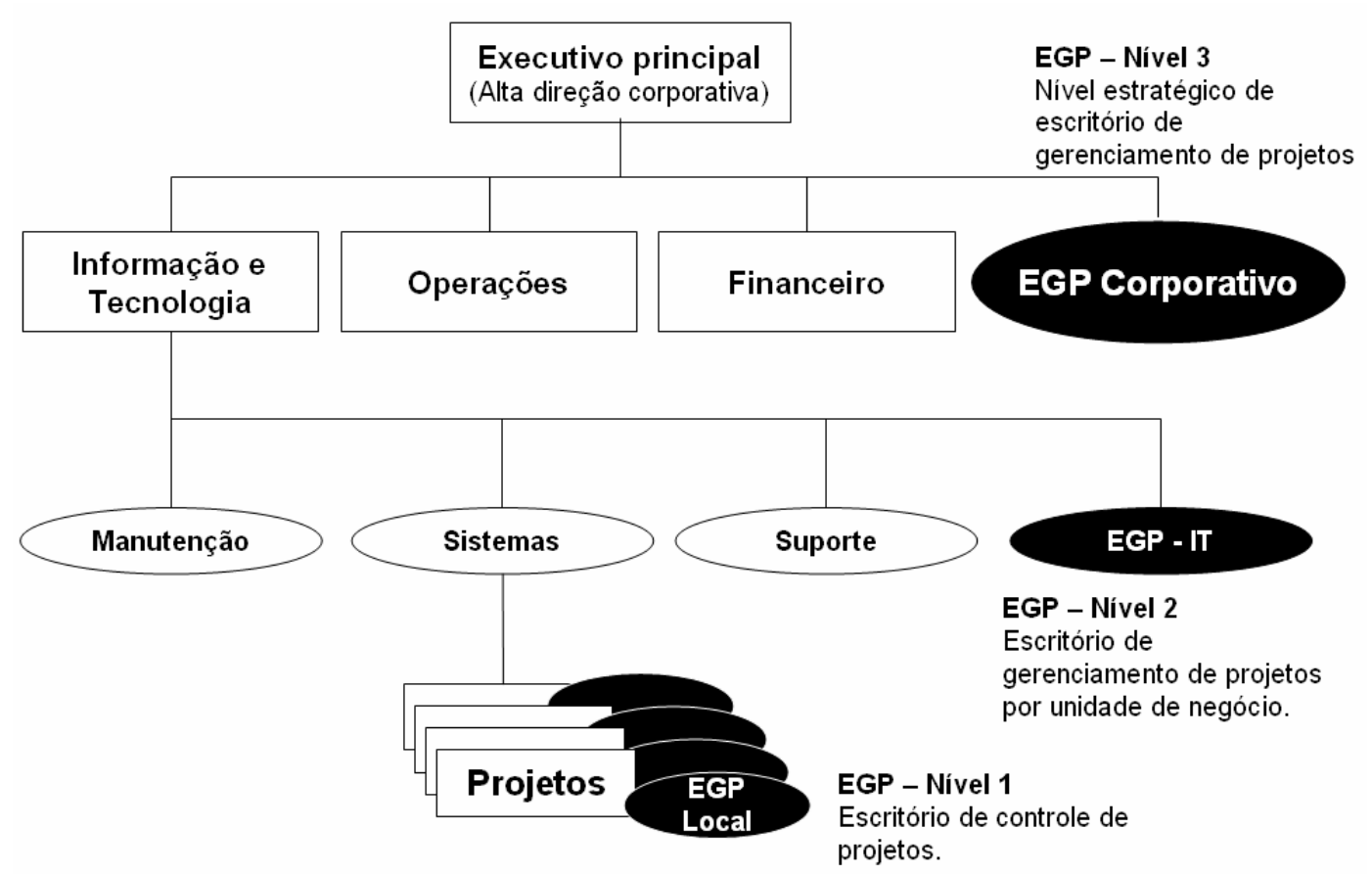

Figura 13 - A localização de um EGP dentro da hierarquia organizacional. Os três possíveis tipos de EGPs estão associados ao escopo de atuação dentro da hierarquia de uma empresa.

(CRAWFORD, 2002, p. 56, tradução nossa) 
A forma pela qual eles são adicionados dentro do modelo corporativo, também se apresenta como uma preocupação comum dos principais autores. Fatores como a natureza dos negócios, culturas organizacionais e as relações humanas e de poder, devem ser cuidadosamente mapeadas e consideradas durante o processo de implementação de um EGP.

\subsubsection{Implementação de escritórios de gerenciamento de projetos}

Os EGPs representam uma sofisticação administrativa que deve estar suportada pelo valor que pode ser proporcionado à uma organização. Um EGP deve estar dimensionado para efetivamente ajudar os níveis executivos na implementação de suas estratégias, pois do contrário, a existência ou necessidade de um EGP torna-se questionável (KENDALL; ROLLINS, 2003).

Freqüentemente, as companhias que decidem por utilizar estruturas como EGPs cometem o erro de optar por uma implementação inicial carregada de funcionalidades, sofisticações e complexidades, que acaba por reduzir as suas possibilidades de sucesso dentro da organização. Os executivos que decidem por implementar estruturas como EGPs devem levar em consideração que a própria necessidade já indica que a empresa precisa evoluir no entendimento destes conceitos. Uma abordagem inicial mais modesta e focada pode proporcionar uma percepção imediata de valor, aumentando as chances de sucesso da iniciativa (KERZNER, 2004 ; TUCKER; AGOPIAN, 2006).

Portanto, antes de decidir-se por implementar um EGP, uma organização deve avaliar com cuidado a real necessidade e o escopo de atuação, seja ele restrito a um departamento ou corporativo, evitando construir uma estrutura que não produz valor efetivo ou ainda o valor proporcionado não justifica os custos de sua existência. As seguintes perguntas devem ser respondidas antes de se decidir pela iniciativa de implementar um EGP (DINSMORE; GRAHAM; ENGLUND, 2003):

- Qual o tamanho da organização, ou subunidade dela, a que se prestarão os serviços do EGP? 
- Existe demanda efetiva para justificar a necessidade de um EGP?

- Quais serão os serviços ou informações desejáveis, supridos pelo EGP aos seus clientes?

- Quais serão os principais obstáculos a serem superados na implementação do EGP;

- Quais características peculiares do negócio e cultura da organização que são compatíveis com a visão e conceitos que permeiam um EGP?

Mesmo diante das dificuldades e as estatísticas verificadas nos históricos de projetos dentro das organizações ${ }^{12}$, na prática, o que se verifica é que a implementação de um EGP vem sempre acompanhada de grandes percalços e dificuldades de aceitação pela própria organização.

Tanto executivos, áreas demandantes, bem como os recursos de projetos, em que se inclui os próprios gerentes de projetos, freqüentemente demonstram resistência diante das iniciativas de se implementar um EGP. Em geral, estas reações se devem, principalmente, aos seguintes motivos (DINSMORE; GRAHAM; ENGLUND, 2003; KENDALL; ROLLINS, 2003 ; CRAWFORD, 2002):

- A cultura imediatista que permeia os ambientes corporativos que exigem resultados rápidos;

- A percepção de uma burocracia adicional em processos de qualificação, planejamento, execução e controle de projetos;

- A percepção de inércia no tempo de resposta de uma necessidade;

\footnotetext{
12 Um estudo realizado na década de 1990 nomeado "The Chaos Report" (STANDISH GROUP, 1994), através de uma pesquisa envolvendo cerca de 350 empresas e 8000 projetos de tecnologia nos Estados Unidos, revelou os seguintes números:
}

- Cerca de $31 \%$ dos projetos foram cancelados antes do término;

- Cerca de $53 \%$ foram completados, porém:

- Apresentaram custos $189 \%$ além do estimado;

- Apresentaram prazos $222 \%$ além do estimado.

- Apenas $16 \%$ foram completados no prazo e orçamento previstos. 
- A submissão das áreas ou mesmo dos gerentes de projetos a um processo e metodologia padrão para a condução de projetos;

- Exposição das administrações ou atividades diante da presença supervisora de um EGP.

Uma visão evolutiva para EGPs pode ser uma saída para a sua devida implementação. A sua implementação, em estágios, pode reduzir os problemas organizacionais de conflitos e cultura, bem como pode garantir uma percepção gradual de valor dentro das organizações (TUCKER; AGOPIAN, 2006). Neste sentido, um EGP deve evoluir de um modelo que atua em níveis funcionais táticos para um escopo de trabalho mais abrangente e estratégico.

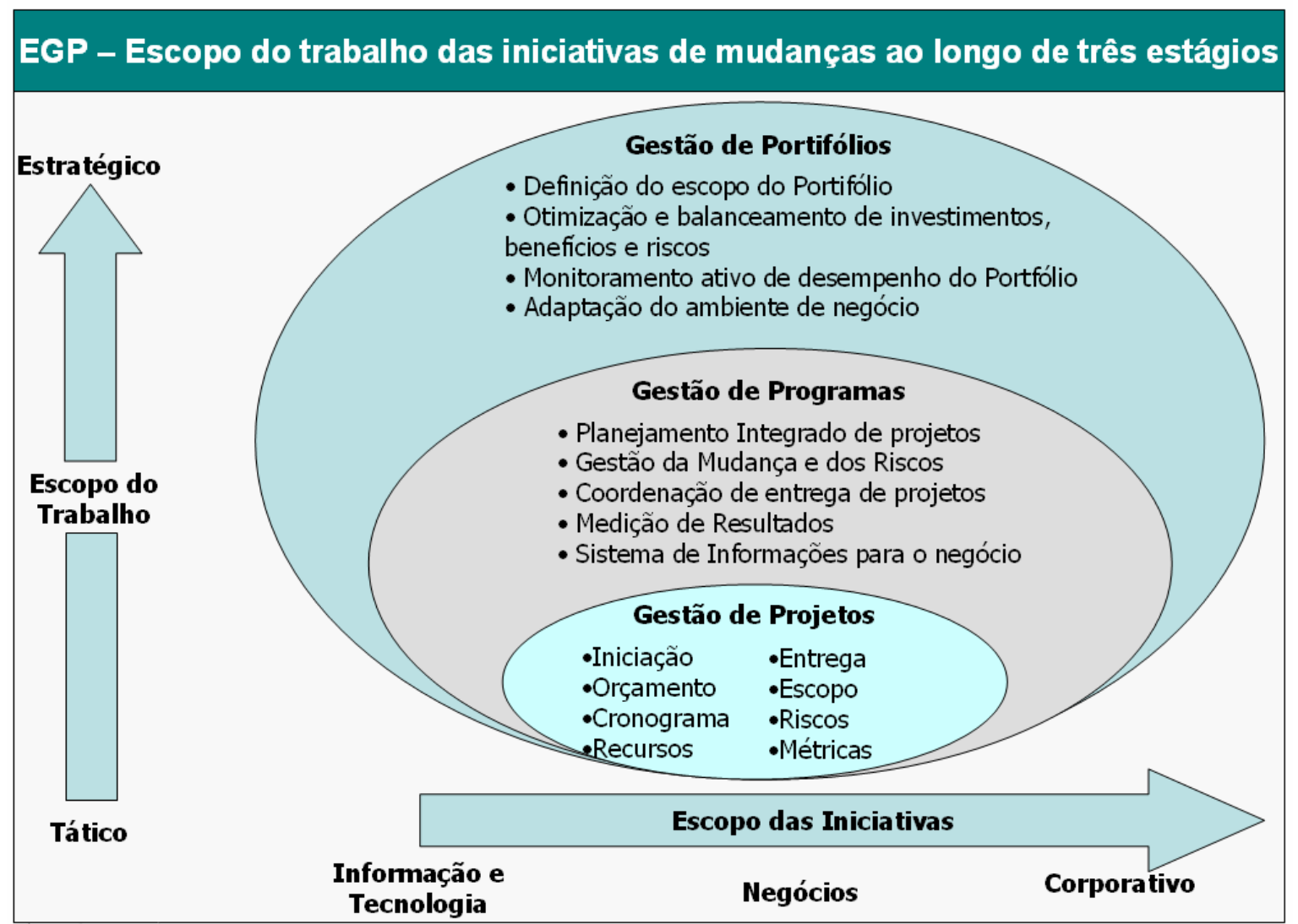

Figura 14 - O escopo do trabalho do Escritório de Projetos em Estágios. As bolhas crescentes simbolizam a abrangência do escopo de trabalho do EGP a cada estágio de evolução. O estado inicial de um EGP que corresponde à gestão isolada de projetos, impondo um caráter tático e operacional em suas funções. No segundo estágio, o EGP passa a atuar no nível de programas e em ambientes com um maior nível de complexidade e risco. No seu último estágio evolutivo, o EGP passa a atuar no nível do porta-fólio de projetos corporativos, permitindo aos executivos da organização obter uma visão consolidada, principalmente sobre os custos, dos investimentos em regime de aprovação ou em execução.

(TUCKER; AGOPIAN, 2006, p. 11, tradução nossa) 
A figura 14 ilustra os três estágios evolutivos propostos. Esses estágios compreendem:

- Gestão de Projetos - O estado inicial de um EGP que corresponde à gestão isolada de projetos, impondo um caráter tático e operacional em suas funções. As disciplinas relacionadas às boas práticas da gestão de projetos devem estar estabelecidas e sendo praticadas de forma sistemática antes que se possa evoluir para o estágio posterior. Neste estágio é recomendável que as seguintes funções estejam sendo praticadas de forma madura:

- Desenvolvimento, implementação e suporte em processos e ferramentas de gestão de projetos;

- Controle e acompanhamento centralizado para todos os projetos;

- Treinamento e coordenação de gerentes de projetos;

- Mentoração e aconselhamento de gerentes de projetos.

- Gestão de programas - Um programa corresponde a um grupo de projetos correlatos e dependentes que atendem a um objetivo comum. Neste estágio, o EGP passa a atuar em ambientes com um maior nível de complexidade e risco. A interação com áreas de negócio passa a ser mais intensa e o ambiente torna-se explicitamente multidisciplinar. A gestão de recursos e da comunicação passa a demandar abordagens mais elaboradas e é neste estágio que ocorre uma percepção da alta direção e das áreas de negócio do valor proporcionado por um EGP. As seguintes funcionalidades devem ser amadurecidas:

- Gestão integrada de recursos;

- Gestão de projetos e programas;

- Gestão de riscos;

- Sistema integrado de informações. 
- Gestão de porta-fólio - No seu último estágio evolutivo, o EGP passa a atuar no nível do porta-fólio de projetos corporativos, permitindo aos executivos da organização obter uma visão consolidada, principalmente sobre os custos dos investimentos em regime de aprovação ou em execução. As atribuições neste nível aproximam o EGP de atividades de planejamento estratégico, na medida em que ajuda os executivos da organização a responder questões relacionadas a correta e racional utilização de recursos dentre diversas possibilidades de investimentos.

Outros autores defendem que a implementação de EGPs deve ser orientada por um processo de mudança organizacional e deve ocorrer pelo devido planejamento das seguintes fases (DINSMORE; GRAHAM; ENGLUND, 2003):

- FASE 1 : Criar condições para a mudança - Nesta fase é necessário que se apresente o problema, a solução adequada e se crie o senso de urgência na implementação da solução. É importante que nesta fase busque-se:

- Desenvolver alianças políticas junto à alta direção, executivos, departamentos e principalmente junto aos potenciais opositores;

- Formar uma equipe capacitada para o dimensionamento e implementação do EGP;

- Desenvolver uma visão para o modelo de EGP desejado e sua estratégia de implementação;

- Comunicar e promover os conceitos e benefícios de um EGP internamente.

- FASE Il: Execução- Nesta fase, a implementação do EGP se inicia efetivamente e deve-se ter atenção para que se garanta:

- Ganhos imediatos ou de curto prazo. É altamente recomendável que se produzam resultados imediatamente, mesmo que pequenos; 
- Comunicar e difundir os resultados iniciais para que a percepção de ganho e valor pela presença do EGP seja efetiva.

- Consolidar as conquistas imediatas e promover as implementações de maiores impactos, cujo caráter delineará as principais resistências e conflitos internos.

- FASE III: Consolidação - Nesta fase, deve-se dar especial atenção à garantia de que os modelos de processos e metodologias estão definitivamente incorporados nos procedimentos padrões da organização. Resistências e padrões culturais incompatíveis ainda persistem e devem ser trabalhadas de forma assertiva e persistente para que se garanta uma mudança de forma definitiva.

Um constatação do perfil de EGPs em empresas no Brasil revela que as empresas que já possuem alguma estrutura semelhante ou equivalente a um EGP são em sua maioria empresas de grande porte, tanto quanto ao número de empregados e faturamento, quanto pela quantidade de projetos empreendidos por ano. Este perfil demonstra uma relação entre o sucesso de implementação de um EGP com a real capacidade e necessidade de uma organização que derivarão em iniciativas bem estruturadas e devidamente apoiadas pela alta direção de uma corporação (BARCAUIU; QUELHAS 2004).

\subsubsection{Funções de um EGP}

O padrão desejável de atuação de um EGP deve variar de acordo com as necessidades de uma organização, bem como das possibilidades e capacidades internas disponíveis. A maturidade no desempenho das suas funções é um importante fator de sucesso já que também determina a credibilidade da estrutura diante de seus clientes internos. 
É possível apontar o EGP como um elo entre a alta administração e os demais níveis táticos e operacionais da empresa, onde na verdade são empreendidos os projetos. Para níveis de atuação com caráter corporativo, um EGP deve exibir um conjunto de atribuições que estejam compatíveis com as necessidades gerais das diversas unidades de negócio, bem como da alta gestão da empresa, permitindo estabelecer uma percepção de seu valor nos diversos níveis organizacionais.

As iniciativas de implementação de EGPs, que desejam consolidar-se como uma unidade corporativa de caráter estratégico, devem apresentar as seguintes funcionalidades e atribuições (KENDALL; ROLLINS, 2003; CRAWFORD, 2002):

- Direcionamento e controle de projetos - O EGP deve garantir que os projetos sob sua supervisão estão sendo encaminhados e gerenciados de acordo com padrões pré-definidos em cada uma de suas fases;

- Facilitador no processo de seleção de projetos - O EGP deve aportar metodologias, técnicas e ferramentas, bem como informações para ajudar os executivos de uma organização a tomarem decisões no que diz respeito a seleção de projetos, apoiando inclusive o processo de planejamento estratégico na formação de um porta-fólio corporativo;

- Facilitador no processo de priorização de projetos - Ainda que definidas no processo de formação de porta-fólio de projetos, a priorização de projetos é uma atividade dinâmica que deve ser observada durante todo o ciclo de gestão de um porta-fólio. A tarefa de revisar a priorização de projetos faz-se necessária principalmente pelas mudanças de cenários internos e externos, bem como pelo desempenho apresentado pelos projetos. Tendo o domínio das informações da atual configuração do porta-fólio, do desempenho dos projetos e alocação dos recursos, o EGP deve ajudar os executivos de uma organização a tomarem decisões no que diz respeito a reformulação das prioridades dentro de uma carteira de projetos; 
- Priorização sistêmica de recursos- O EGP, entendendo as prioridades estratégicas da organização, dos projetos e conhecendo a atual configuração do porta-fólio de projetos, deve encaminhar e supervisionar a correta alocação de recursos humanos e financeiros da organização nos projetos corporativos;

- Painel executivo de acompanhamento do porta-fólio de projetos corporativos - O EGP deve prover informações estruturadas, atualizadas e consolidadas da atual posição do portafólio de projetos corporativos, indicando seu balanceamento de riscos, retorno, tipos de projetos e orientação em relação à estratégia corporativa;

- Painel executivo de acompanhamento de projetos - O EGP deve prover informações de caráter gerencial que permitam os executivos acompanhar o desempenho dos projetos em andamento, bem como avaliar se estes estarão atendendo os objetivos para os quais foram designados;

- Aporte de metodologia, ferramentas e processos - O EGP deve prover, seja por modelos pré-concebidos, adaptados ou desenvolvidos internamente, um conjunto de processos, métodos e ferramentas que garantam padronização e qualidade nas atividades de gestão dos projetos da organização;

- Aconselhamento, mentoração, suporte e treinamento de gestão de projetos - O EGP deve criar as condições necessárias para que as equipes responsáveis pela gestão bem como a execução dos projetos sejam orientadas e desenvolvidas de acordo com as boas práticas e metodologias estabelecidas para a gestão de projetos da organização;

- Ações corretivas - O EGP deve manter atenção nas principais causas dos problemas que afetam os resultados de um projeto, sejam de escopo, custos, prazos e qualidade, buscando identificar e implementar as ações necessárias de correção;

- Repositório de informações e lições aprendidas - O EGP deve manter um acervo de conhecimentos, históricos e lições aprendidas 
nos projetos empreendidos pela organização. Todo o conhecimento acumulado deve ser disponibilizado de forma organizada e de fácil acesso a todos os interessados e envolvidos nos assuntos que dizem respeito a administração dos projetos da organização .

Kerzner destaca outras três importantes atribuições que um EGP deve estar preparado a atender(KEZNER, 2004):

- Desenvolvimento de sumários executivos (Business Case) - Em geral, sumários executivos, desenvolvidos sob a exclusiva orientação da área interessada no projeto, estão sujeitos a refletirem resultados e cenários tendenciosos e quase sempre otimistas, não representando adequadamente as realidades inerentes dos custos e prazos envolvidos na execução de um projeto. Um outro problema verificado é a falta de padronização nos formatos das proposições, criando uma diversidade de abordagens na elaboração de sumários executivos. Um EGP pode apoiar processos de planejamento estratégico corporativos pela sua contribuição como um especialista de caráter imparcial no desenvolvimento de estudos de viabilidade e análises de custobenefício para as novas proposições de projetos, impondo também formatos e modelos comuns de elaboração;

- Gestão dos principais interessados nos projetos (Stakeholders) - Um EGP pode representar um grande potencial como ferramenta de construção de relacionamentos e alianças, bem como no gerenciamento de conflitos de interesses entre os principais envolvidos nos projetos corporativos. Alianças e parcerias internas e externas também podem ser desenvolvidas em favor da viabilização de projetos específicos e de grande importância;

- Gestão e planejamento da capacidade - Uma importante informação demandada pelos executivos responsáveis pelo planejamento estratégico é a atual capacidade de execução de projetos da organização, bem como os impactos provocados pela adição de novos projetos. O EGP deve manter um controle 
atualizado da atual distribuição dos recursos humanos da organização nos projetos, bem como das possibilidades de absorção de novas demandas ou ainda das necessidades de incorporação de novos recursos ou competências específicas.

A revisão dos conceitos que permeiam as atribuições e funcionalidades de EGPs dentro dos arranjos organizacionais, apontam um consenso entre as várias fontes sobre possibilidades de agregar estas estruturas dentro dos modelos decisórios de cunho estratégicos.

No que se diz respeito à correta definição de um conjunto de investimentos corporativos, os objetivos e metas definidos pelo planejamento estratégico irão demandar, das diversas unidades que compõe uma organização, esforços para compor uma carteira de projetos que reflitam as ações necessárias para que uma estratégia seja cumprida.

A diversidade de disciplinas, especializações e níveis hierárquicos, bem como a diversidade humana a que uma organização pode estar sujeita infere que as propostas de projetos podem, e em geral, estão dimensionadas sob diferentes pontos de vista e padrões de comunicação (RASMUSSEN et al., 2003; MOORE, 1999).

Portanto, verifica-se uma complementaridade entre as necessidades de processos como planejamento estratégico e orçamentário com as competências específicas de um EGP, que, supostamente, possui o conhecimento necessário na disciplina de gestão de porta-fólio de projetos.

Um EGP pode contribuir neste cenário como elemento de comunicação e controle, bem como de orientação e padronização das informações necessárias à tomada de decisão, necessária para a composição e gestão de um porta-fólio de projetos corporativos.

Desta forma, pode-se complementar o modelo de planejamento estratégico, representado pelos processos ilustrados na figura 15, atribuindo-se ao EGP 
corporativo uma participação orientada às demandas verificadas pelas atividades de seleção e composição de um porta-fólio de projetos corporativos.

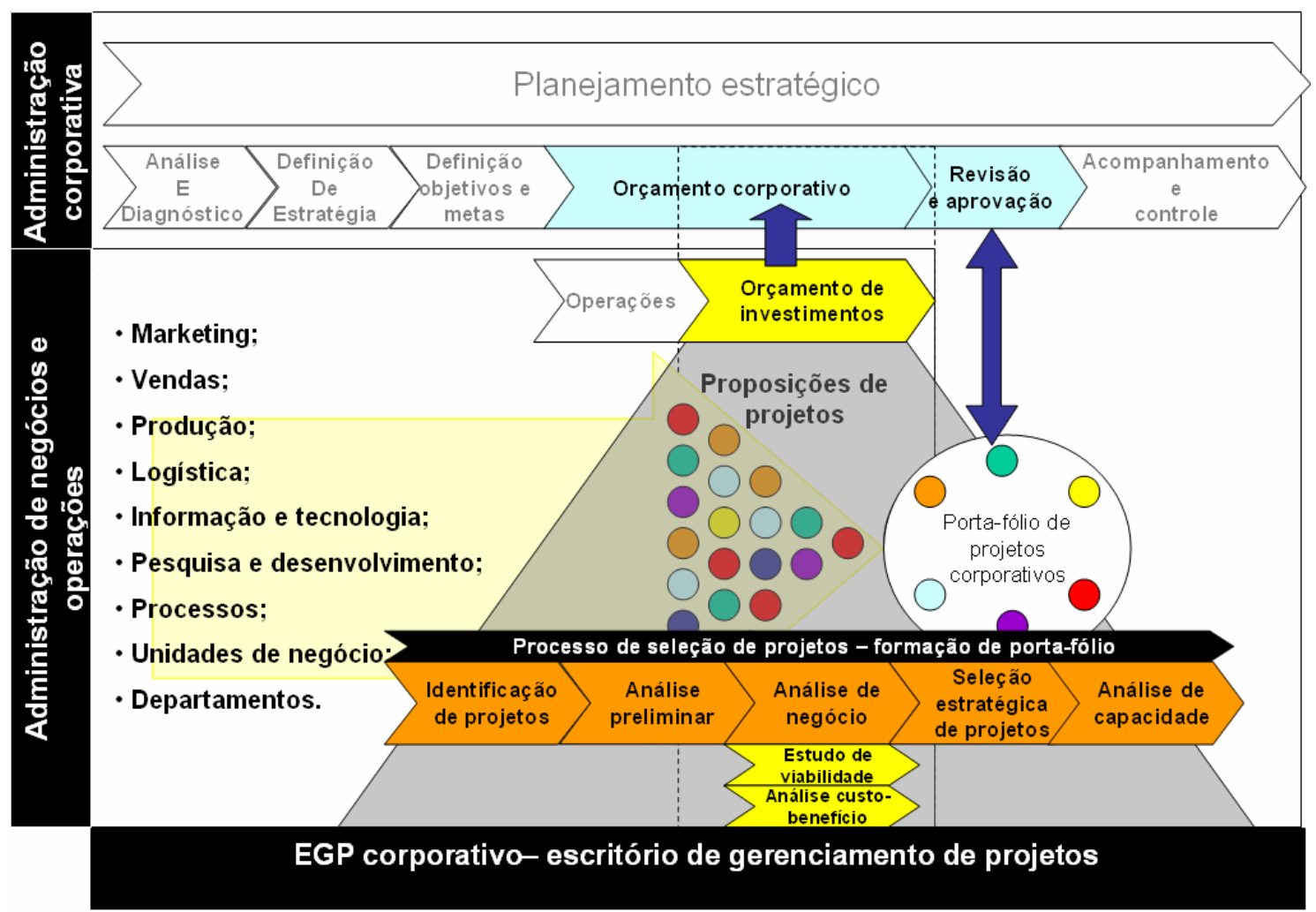

Figura 15 - EGP atuando como apoio no planejamento estratégico e orçamentário. A coluna da esquerda indica as hierarquias envolvidas em cada um dos processos indicados pelas setas largas. As setas menores indicam o fluxo de informação que permeia entre os envolvidos no processo. Os círculos coloridos representam as proposições de projetos a serem orçadas e aprovadas. A geração de propostas de projetos ocorre, em geral pelas manifestações das áreas de negócio diante de suas percepções de riscos e oportunidades, representadas à esquerda na figura. Em destaque apresenta-se a incorporação do EGP, na parte inferior do diagrama, como elemento de coordenação e apoio do processo de seleção de projetos que apoiarão a tomada de decisão na formação de um porta-fólio de projetos, representado pelo circulo maior à direita. 


\section{Metodologia da pesquisa}

O presente trabalho caracteriza-se por ser uma pesquisa aplicada, pois objetiva gerar conhecimentos para aplicação prática e dirigidos à solução de problemas específicos. Uma vez que se qualifique um problema e a motivação para se empreender uma análise, o pesquisador busca conhecimentos em um modelo epistemológico que possa reduzir sua impotência diante de uma realidade constatada. A pesquisa científica exige, portanto, o rigor de um método para enquadrar uma realidade diante do conhecimento disponível, para posteriormente gerar um novo conhecimento ou uma nova perspectiva diante de um problema.

Pesquisar significa, de forma bem simples, procurar respostas para indagações propostas. A seleção de um instrumental metodológico está diretamente relacionada com o problema investigado e depende de vários fatores. Em geral, a natureza do fenômeno estudado e o objeto da pesquisa são elementos a serem considerados na escolha de uma abordagem (LAKATOS; MARCONI, 2003). Os questionamentos levantados neste trabalho estão atrelados a contextos sociais e organizacionais que devem, portanto, ser considerados na escolha de uma metodologia para que se possa investigar o problema proposto.

Toda a investigação nasce de algum problema teórico ou prático observado. O que é relevante ou irrelevante observar, os dados que devem ser selecionados, serão os objetos de estudo. Neste estudo, existe o predomínio da vivência prática como o fator motivador. A vivência dentro do contexto da pesquisa é o principal instrumento de observação para análise e conclusões. Considerado esses aspectos e o predomínio de relações organizacionais profissionais inerentes do problema, a abordagem de pesquisa selecionada foi norteada pelo modelo de pesquisa qualitativa.

A abordagem qualitativa é perfeitamente aplicável quando existe uma relação dinâmica entre o conteúdo em estudo, o mundo real e o sujeito, que não pode ser traduzida em números. O ambiente natural é a fonte direta para coleta de dados e o 
pesquisador é o instrumento chave (SILVA; MENEZES, 2005). A interpretação dos fenômenos e a atribuição de significados são básicas no processo de pesquisa qualitativa.

Neste trabalho, em um sentido mais elementar, buscou-se identificar uma seqüência lógica que conecta dados empíricos às questões de estudo e, em última análise, às suas conclusões, permitindo estabelecer inferências relativas às relações causais entre as variáveis investigadas. Para a forma de apresentação dos dados coletados, utiliza-se uma abordagem descritiva, já que os fenômenos estudados apresentam um caráter qualitativo muito intenso.

Cabe ainda acrescentar ao presente estudo o caráter do método científico a ser aportado. Um método científico é constituído de um conjunto de processos e modelos mentais que se devem empregar em toda investigação. É a linha de raciocínio adotada no processo de pesquisa. Os métodos científicos que fornecem as bases lógicas à investigação são: dedutivo, indutivo, hipotético-dedutivo, dialético e fenomenológico (GIL, 1999; LAKATOS; MARCONI, 1993 apud SILVA; MENEZES, 2005).

Devido o caráter empírico e qualitativo que norteia este trabalho e o objeto de estudo, que é permeado de relações humanas em contextos organizacionais, 0 método selecionado foi o da lógica indutiva.

No método indutivo, o conhecimento é fundamentado na experiência, não levando em conta princípios pré-estabelecidos. No raciocínio indutivo, a generalização deriva de observações de casos da realidade concreta. As constatações particulares levam à elaboração de generalizações (GIL, 1999; LAKATOS; MARCONI, 1993 apud SILVA; MENEZES, 2005).

O método da indução é um processo mental por intermédio do qual, partindo-se de dados particulares, suficientemente constatados, infere-se uma verdade geral ou universal, não contida nas partes examinadas. Portanto, o objetivo dos argumentos indutivos é o de levar a conclusões cujo conteúdo é muito mais amplo do que o das premissas nas quais eles se basearam. Importante ressaltar que, tal como no 
método dedutivo, o indutivo faz emprego de premissas, porém, neste último, essas conduzem apenas a conclusões prováveis.

Induzir é tirar uma conclusão a partir de um ou mais fatos particulares ou a partir de provas e, portanto, a conclusão indutiva é uma concordância inferencial além das provas apresentadas. Neste sentido, muito embora uma conclusão possa explicar um fato, outras conclusões também podem ter esse mesmo efeito (COOPER; SCHINDLER, 2003).

O método científico da indução deve ser realizado em três etapas (LAKATOS; MARCONI, 2003):

- Observação dos fenômenos - Fatos ou fenômenos são observados e analisados com a finalidade de se descobrir as causas de sua manifestação;

- Descoberta da relação entre eles - Por intermédio de comparação, busca-se aproximar os fatos ou fenômenos através de evidências que possam indicar uma relação constante entre eles;

- Generalização da relação - Ocorre a generalização da relação encontrada para fatos ou fenômenos semelhantes.

Este trabalho não tem a pretensão de estabelecer uma correlação entre causas e efeitos evidenciados de forma estatística, mas sim chamar a atenção para uma possível abordagem na resolução de um problema comum nas organizações. Portanto, a meta deste estudo não é a de provar uma verdade universal, mas sim indicar uma possibilidade. Neste sentido, o caráter do método indutivo apresenta uma grande vantagem devido à sua flexibilidade em permitir que hipóteses possam ser constatadas por intermédio de inferências, ainda que reduzidas a um universo restrito de validação. A técnica permite também maior flexibilidade na exploração de informações qualitativas.

Do ponto de vista de procedimentos técnicos, o presente estudo fez uso de duas abordagens, entre outras possíveis para pesquisas científicas (GIL, 1991): 
- Pesquisa bibliográfica: quando elaborada a partir de material já publicado, constituído principalmente de livros, artigos de periódicos e atualmente com material disponibilizado na Internet.

- Estudo de caso: quando envolve o estudo profundo e exaustivo de um ou poucos objetos de maneira que se permita o seu amplo e detalhado conhecimento.

A pesquisa bibliográfica se constitui em um importante elemento de apoio deste trabalho já que se buscou evidenciar, nos diversos assuntos envolvidos, uma cadeia lógica de relações, causas e efeitos que propiciaram uma visão do problema investigado sob um novo enfoque.

A pesquisa bibliográfica tem por finalidade colocar o pesquisador em contato direto com tudo o que já foi levantado sobre determinado assunto e uma revisão estruturada permite ao cientista um reforço paralelo na análise de sua pesquisa e neste sentido, não pode ser considerada uma mera repetição do que já foi escrito sobre certo assunto. Ela permite o exame de um tema sob um novo enfoque ou abordagem, podendo chegar a conclusões inovadoras (LAKATOS; MARCONI, 2003).

Já o estudo de caso pode ser considerado como uma das muitas maneiras de fazer pesquisa em ciências sociais. Experimentos, levantamentos, pesquisas históricas e análise de informações em arquivos são alguns exemplos de outras maneiras de se realizar uma pesquisa. Cada estratégia apresenta vantagens e desvantagens e estas dependem basicamente de três condições (YIN, 2005):

- O tipo de questão da pesquisa;

- O controle que o pesquisador possui sobre os eventos comportamentais efetivos;

- O foco em fenômenos históricos em contraposição a fenômenos contemporâneos. 
Os estudos de caso representam uma boa estratégia quando o pesquisador possui pouco controle sobre os acontecimentos e quando se trata de estudo de fenômenos contemporâneos inseridos em um contexto da vida real. Existe uma complementaridade entre a adoção da estratégia de estudos de caso e as pesquisas com caráter qualitativo ou ainda exploratórios descritivos (YIN, 2005).

Quando a pesquisa trata de estudar fenômenos individuais, organizacionais, sociais, políticos e de grupo, como é o caso deste estudo, a recomendação da estratégia de estudos de caso é forte. De forma não surpreendente, o estudo de caso tem se estabelecido como uma estratégia muito utilizada para pesquisas em áreas como psicologia, sociologia, ciências políticas e administração (GILGUN, 1994 apud YIN, 2005).

Embora muito difundido e versátil, o estudo de caso também tem sido objeto de críticas e muitos cientistas sociais acreditam que seu uso é mais apropriado em pesquisas de caráter exploratório. Muitas das críticas levantadas, relativas ao uso desta estratégia, são devidas ao uso ou desenvolvimento inadequado. Um outro ponto de crítica muito comum no meio científico é de que os estudos de caso fornecem pouca base para se fazer uma generalização científica.

Por outro lado, muitos pesquisadores adotam a estratégia de estudos de caso em pesquisas de caráter qualitativo. A justificativa é de que os resultados obtidos são mais ricos e significativos quando a pesquisa envolve questões de ciências sociais, políticas e administração. O aporte de análises quantitativas e estatísticas em estudos de caso para pesquisas nestas áreas pode apresentar vieses já que os resultados podem não ser conclusivos de imediato e ao mesmo tempo podem ofuscar importantes informações que poderiam ser facilmente extraídas se a abordagem fosse qualitativa (GROSSHANS; CHELIMSKY,1990).

Yin define estudo de caso como uma proposta de cunho empírico que investiga um fenômeno contemporâneo dentro de seu contexto da vida real quando os limites entre o fenômeno estudado e o contexto da pesquisa não se apresentam muito claros, tal como evidenciado no presente trabalho (YIN, 2005). 
O estudo de caso apresentado neste trabalho de pesquisa foi resultante da observação, catalogação e análise das práticas de planejamento estratégico, orçamentário e gestão de porta-fólio de projetos corporativos de uma empresa nacional do ramo de mídia. A coleta de dados foi realizada entre o período do segundo semestre de 2004 e o último semestre de 2006.

As evidências apresentadas foram obtidas principalmente pela compilação e análise de:

- Levantamentos históricos, através de entrevistas efetuadas junto às áreas da organização;

- Dados levantados da vivência dentro do contexto organizacional apresentado;

- Um mapeamento e esquematização de processos, através de entrevistas envolvendo as áreas de:

- Financeiro;

- Suprimentos;

- Produção;

- Tecnologia;

- Áreas Comerciais.

Portanto, o material que embasa o desenvolvimento do estudo de caso apresentado está categorizado nas seguintes formas de evidências:

- Documentação - Relatórios administrativos e de consultorias, bem como mapeamentos de processos desenvolvidos ou levantados, que permitiram extrair importantes informações sobre o contexto em estudo;

- Entrevistas - Que permitiram enriquecer o conhecimento do contexto em estudo sob a perspectiva dos envolvidos no problema nas diversas áreas da empresa investigada;

- Observação direta - Que ocorreram pela observação informal do contexto em estudo, nas interações onde não existiu a influência do pesquisador. Neste caso, incluem-se os aspectos relativos à percepção do problema em estudo nas diversas áreas da empresa investigada; 
- Observação participante - Que ocorreram pela vivência do pesquisador em uma parte limitada funcionalmente no contexto em estudo, como um colaborador na empresa investigada.

Como metodologia de análise, a pesquisa fez uso da técnica analítica denominada de construção da explanação, que pode ser classificada como uma variante, ou tipo especial, da técnica de adequação ao padrão (YIN, 2005). Nesta técnica, explica-se o fenômeno em estudo através de um conjunto presumido de elos causais em um modelo gradual de refinamentos.

Esta natureza iterativa da construção da explanação exige que se explorem as proposições e evidências teoricamente significativas. Como roteiro geral da técnica, pode-se utilizar os seguintes passos:

- Cria-se uma declaração ou proposição teórica inicial sobre o comportamento do fenômeno em estudo;

- Comparam-se as descobertas do estudo de caso com a declaração teórica ou proposição inicial;

- Revisa-se a declaração teórica ou proposição inicial;

- Comparam-se outros detalhes do caso com a revisão;

- Revisa-se novamente a declaração teórica ou proposição inicial;

- Repete-se este processo tantas vezes quanto necessário.

Neste estudo de caso, a proposição teórica inicial foi desenvolvida com base na construção de relacionamentos e elos identificados por uma revisão bibliográfica das várias disciplinas abordadas pelo problema em estudo, estabelecendo-se um modelo de hipóteses que é apresentado na seção 3 deste trabalho. No estudo de caso, apresentado na seção 5 , estabelece-se então a comparação dos principais elementos de referência da teoria, que permeia o modelo proposto, com as evidências identificadas na prática. 


\section{Estudo de caso}

\subsection{Contexto econômico e de negócios}

Nesta seção, apresenta-se o ambiente a ser estudado dentro das condições sócioeconômicas que precederam o período deste estudo de caso.

A década de 1990 foi marcada por profundas mudanças dentro do contexto empresarial deste país. A abertura de mercado promovida no início desta década, o controle da inflação a partir do Plano Real, crises econômicas e cambiais e principalmente a consolidação da Internet como meio de interatividade e mídia de conteúdo marcam o cenário desta década de profundas mudanças.

O mercado de mídia impressa também experimentou e vem experimentando transformações contundentes de mercado desde os anos 1990. A explosão de consumo pós Plano Real levou os grupos de comunicação a contraírem pesadas dívidas lastreadas em dólar com objetivos de investirem em grandes projetos de expansão. Com a crise cambial de 1999, a desvalorização do real seguida de forte retração no consumo, as companhias do setor viram-se diante de graves dificuldades (BRASIL EM FOCO, 2005).

Apesar da recuperação econômica a partir de 2002 e dos aumentos nos investimentos em comunicação, a publicidade, buscando canais mais efetivos, vem sistematicamente migrando de veículo. Os Gráficos da figura 16 sustentam essa observação.

A circulação de jornais vem apresentando quedas sistemáticas, ano após ano, não só no Brasil, mas também em outras regiões do globo. Com esse panorama, as empresas de mídia tiveram de encarar duros processos de reestruturações e encolhimento. A profissionalização de suas gestões também foi uma questão de sobrevivência já que, em geral, os grandes grupos de mídia do Brasil são de origem familiar. 

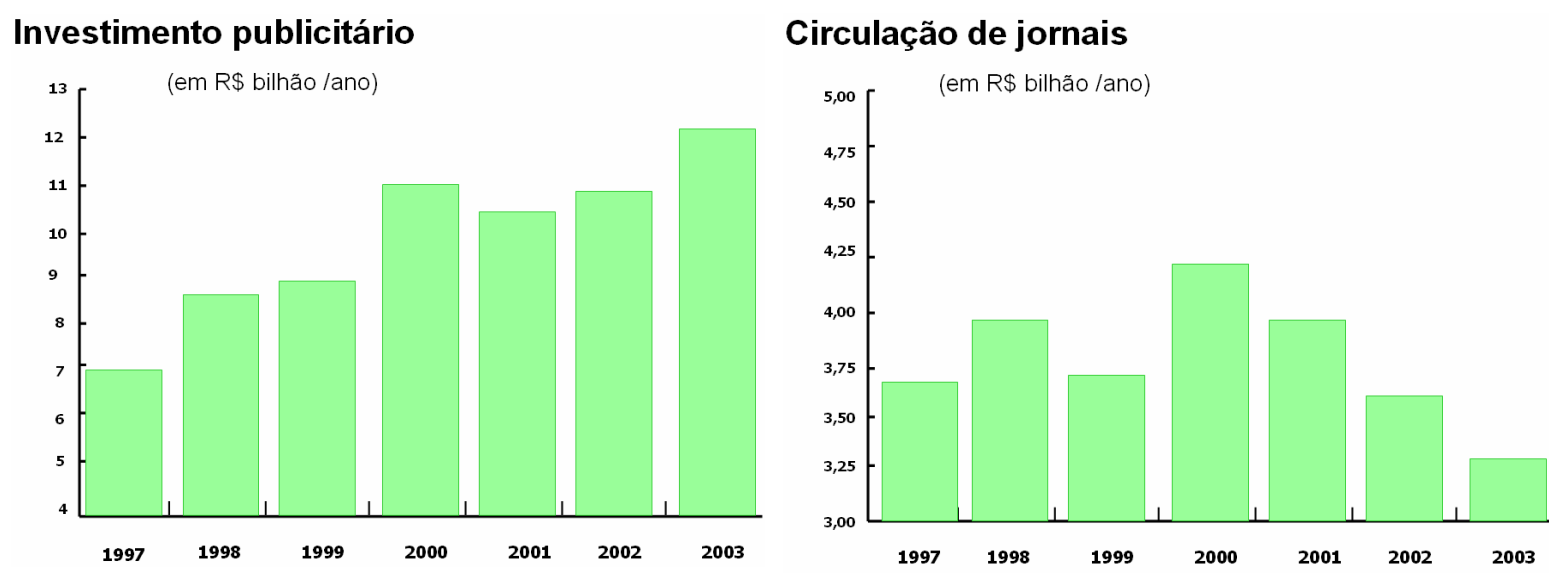

Figura 16 - Desempenho de investimentos em publicidade e circulação de jornais no Brasil. (BRASIL EM FOCO, 2005 p. 59)

Muito embora não se imagine um fim para este tipo de veículo de informação, já é um fato que as empresas que atuam predominantemente neste tipo de mídia sofrerão quedas sistemáticas em suas receitas ainda por muitos anos, principalmente pelo avanço da internet nas mídias publicitárias.

Diante disto, jornais em todo o mundo vêm buscando reinventar o produto impresso através de redesenho gráfico e outras abordagens de conteúdo e redação. Buscam ainda reorientar seus negócios pela adequação de seus produtos para as mídias eletrônicas e internet.

Por outro lado, grande parte dos recursos financeiros destas companhias ainda depende muito da receita de circulação de jornais impressos, o que provoca um grande dilema na capacidade destas empresas em manter seus negócios financeiramente viáveis enquanto buscam um novo modelo de negócio (BRASIL EM FOCO, 2005). 


\subsection{Estrutura e organização do estudo de caso}

Ao longo do texto, o termo grupo, referindo-se a um grupo empresarial, e o termo empresa serão utilizados neste estudo de caso de forma indiscriminada, porém assumindo o mesmo significado, que é o de uma instituição social e corporativa com fins lucrativos instituída legalmente, composta de várias entidades jurídicas ${ }^{13}$. Também, para efeitos de simplificar a narrativa deste estudo de caso, será utilizado doravante o termo IT para fazer referência a(s) área(s) de informação e tecnologia citada(s).

O presente estudo de caso estudou os fenômenos ocorridos durante um processo de reestruturação corporativa em um grupo empresarial brasileiro no ramo de mídia predominantemente impressa. Duas principais transformações, decorrentes da reestruturação mencionada, são os objetos de maior interesse dentro do estudo e são relativos aos:

- Processo de planejamento estratégico e orçamentário;

- Processo de seleção e aprovação de projetos apoiados por um EGP.

As transformações destes dois processos ocorreram de forma simultânea e independente até um determinado momento, quando se verificou uma complementaridade de propostas que proporcionou uma sinergia entre os mesmos, que é o principal elemento de evidência deste trabalho.

Devido o caráter concorrente das duas transformações, este estudo de caso desenvolve-se de acordo com os seguintes tópicos:

- Histórico e a reestruturacão do grupo - Apresenta-se, de forma breve, um histórico do grupo, seguido pela narrativa do processo de

\footnotetext{
${ }^{13}$ Aqui, entidade jurídica se refere à empresa componente do grupo que possui inscrição no Ministério da Fazenda, sob um número do Cadastro Nacional de Pessoa Jurídica - CNPJ.
} 
reestruturação promovido, bem como os motivos pelo qual a transformação se fez necessária;

- O planejamento estratégico e orçamentário - Apresenta-se como o processo de planejamento estratégico e orçamentário do grupo foi impactado pela reestruturação: as práticas adotadas e seus principais problemas;

- Reestruturação da área de IT - Narra a transformação promovida dentro da área de informação e tecnologia do grupo;

- Criação do EGP na área de IT - Narra a implementação de um EGP dentro da área de informação e tecnologia do grupo, bem como os motivos pelos quais se fez necessária esta iniciativa;

- O modelo de gestão de demandas de projetos - Apresenta a contribuição do EGP nos processos de avaliação e seleção de projetos do grupo, que envolvem tecnologia da informação;

- A revisão do processo orçamentário - Apresenta-se a evolução secundária do processo de planejamento estratégico e orçamentário do grupo diante da contribuição proporcionada pelo EGP da área de IT.

Em cada um dos tópicos acima mencionados, insere-se uma seção de comentários e interpretações que se apóia nos modelos e teorias apresentadas na seção 3. Fazse também o uso intensivo de conceitos da Cibernética e do modelo do VSM para avaliação dos problemas de desempenho verificados e as possíveis relações com violações de princípios da Cibernética. (Seção 3.1).

O tempo verbal praticado no estudo de caso também merece algumas observações. A flexão verbal no passado será utilizada intensivamente, procurando indicar eventos ocorridos e que não persistem mais na realidade investigada. Por outro lado, o tempo verbal no presente também pode surgir ao longo da narrativa e tem como objetivo indicar uma situação ou comportamento que persiste, pelo menos, até a conclusão do presente trabalho. 


\subsection{Histórico e a reestruturação do grupo}

O grupo empresarial em estudo apresenta um histórico de mais de 100 anos de existência e um faturamento anual na ordem de centenas de milhões de reais. A direção da empresa, na maior parte de sua existência, é caracterizada por uma administração familiar já que esta foi mantida ao longo de décadas pelas famílias e descendentes de seus fundadores. Ao final da década de 1990, o grupo possuía um contingente de recursos humanos em torno de 6000 funcionários distribuídos em nove entidades jurídicas.

Até o final dos anos 1990 e início dos anos 2000, essas empresas estavam organizadas em unidades de negócio independentes, sendo que cada uma possuía sua própria área administrativa, de apoio à produção e negócios. As áreas administrativas, em geral, estavam distribuídas nas unidades de negócio em células que proviam serviços de:

- Recursos Humanos

- Financeiro

- Contabilidade

- Informação e Tecnologia

Diante dos cenários econômicos e de negócios, apontados na seção 5.1, e diante de uma crescente redução da receita operacional e uma dívida lastreada em Dólar, o grupo experimentou uma grave crise financeira ao final dos anos de 1990, com exposição de seus ativos em uma grande dívida junto a bancos.

Como resposta à situação de crise descrita, a partir do ano de 2000, o grupo iniciou um processo de reestruturação corporativa com objetivo de reduzir custos fixos através da integração das áreas administrativas das diversas empresas componentes.

A reestruturação foi conduzida com o apoio de uma consultoria especializada, cuja linha estratégica foi a de buscar sinergia e integração de recursos pela eliminação 
de redundâncias internas nas atribuições de departamentos e áreas. O modelo adotado foi denominado de CSC - Centro de Serviços Compartilhados.

Neste novo conceito, as diversas empresas que compõem o grupo passaram a ser clientes de uma área comum, que provê serviços e assessoria nas seguintes disciplinas:

- Finanças e controladoria;

- Recursos humanos;

- Suprimentos;

- Jurídico;

- Informação e Tecnologia.

Em decorrência disto, as diversas empresas e unidades de negócios, que compunham o grupo, sofreram uma redução acentuada de suas áreas administrativas e o quadro de funcionários do grupo sofre uma redução substancial. As áreas de negócio passaram, portanto, a operar com um contingente humano reduzido e mais orientado ao negócio.

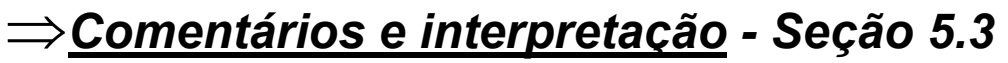

A organização do grupo, antes da reestruturação promovida, pode ser representada pelo VSM (seção 3.1.4), indicando estruturas recursivas presentes nas empresas que compunham o grupo empresarial. A figura 17 ilustra esta configuração, onde as evidências da autonomia administrativa das unidades de negócio e empresas que compunham o grupo podem ser representadas por recursividade semelhante à do meta-sistema ${ }^{14}$ organizacional.

\footnotetext{
${ }^{14} \mathrm{O}$ termo meta-sistema faz referência ao sistema maior, que contêm todos os sistemas em análise. Neste caso, o meta-sistema corresponde ao grupo empresarial em observação.
} 


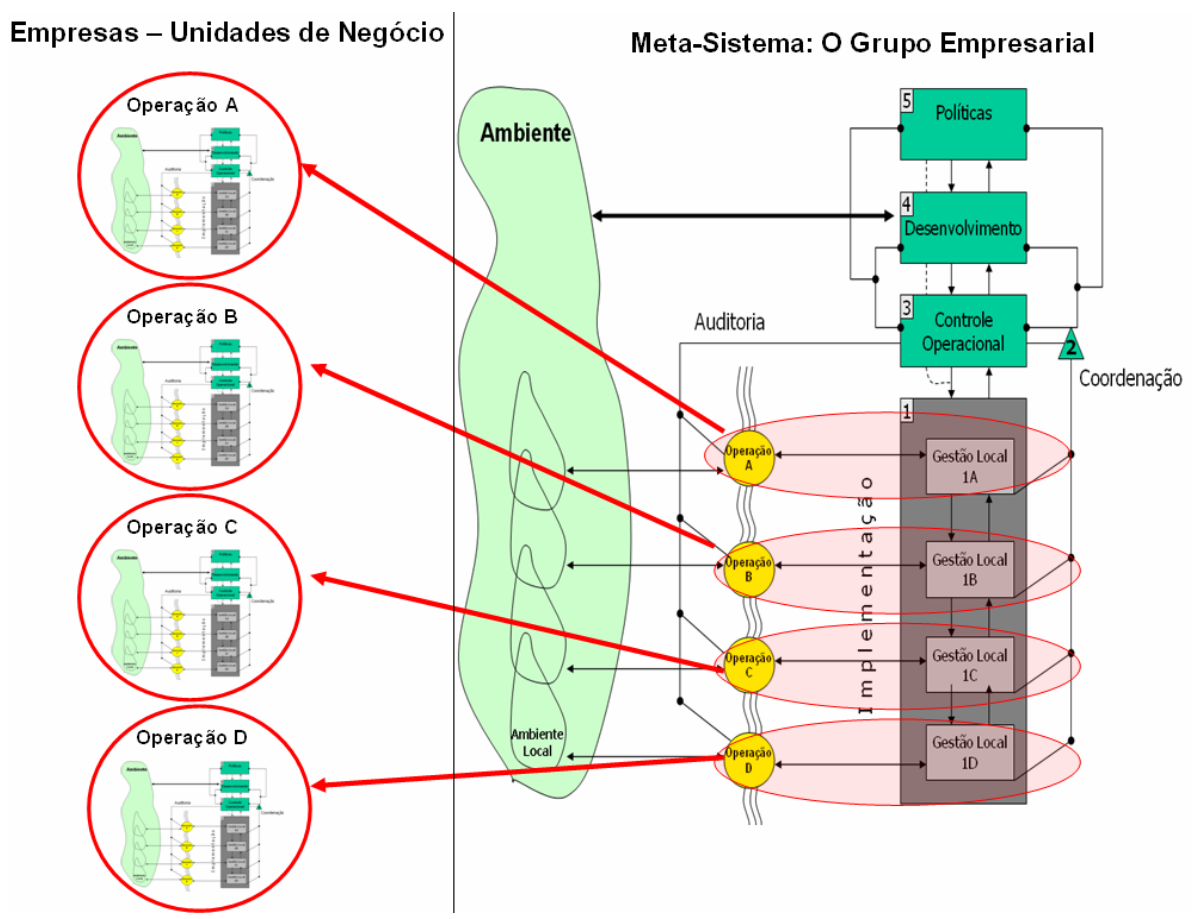

Figura 17 - Visão VSM para a configuração do grupo empresarial antes da reestruturação. As empresas e unidades de negócio, apresentadas pelos sistemas 1 do VSM, possuem estruturas administrativas e de apoio próprias, indicando a presença de sistemas 2 e 3. Neste caso, a recursividade permitida pelo uso do VSM é explorada.

Com as mudanças nos cenários externos de negócios, queda nas receitas operacionais e a situação de dívida crescente evidenciada, o grupo entra em uma crise que pode ser interpretada como um aumento da entropia interna do sistema organizacional e esta manifesta-se por uma ineficiência do sistema em atender os objetivos para os quais ele foi concebido com o desempenho financeiro desejado. $A$ variedade $^{15}$ do ambiente externo aumentou e a variedade interna não está mais compatível com a variedade a ser administrada (Seções 3.1.1 a 3.1.3).

A ação de reestruturação do grupo deve ser encarada como uma ação estratégica de resposta a uma necessidade de reorganização do grupo diante de um cenário de ameaça. Sob a perspectiva da Cibernética, pode-se enquadrar o planejamento estratégico e orçamentário como um mecanismo de homeostase. Este mecanismo opera não só por demanda ou diante de um estímulo externo ou interno, ele opera de também forma cíclica e regular. Ele opera não só para responder às ameaças, mas também para explorarem-se oportunidades.

\footnotetext{
${ }^{15}$ Variedade aqui se refere ao termo introduzido por Ashby e faz referência ao número de possíveis estados que um sistema pode assumir - seção 3.1.5.
} 
Diante de ameaças e oportunidades constatadas do ambiente e diante da missão que norteia os seus negócios, um processo de reformulação é desencadeado internamente - homeostase, redefinindo objetivos e determinando um conjunto de ações necessárias para que se estabeleça:

- Uma nova missão para o organismo;

- Um novo conjunto de objetivos e metas;

- Um planejamento para orientar o balanceamento de variedades internas, necessários para lidar com a variedade da nova realidade (Seção 3.1.3).

Como resposta às mudanças do ambiente externo, o organismo opta pela redução da variedade interna de suas subpartes classificadas como sistema 1. Esta ação está sendo promovida pela introdução de um modelo de CSC, que deve aumentar a variedade e o controle dos sistemas 2 e 3 do meta-sistema organizacional, devido à absorção das atividades desempenhadas até então nos sistemas 1. Esta nova configuração é ilustrada na figura 18.

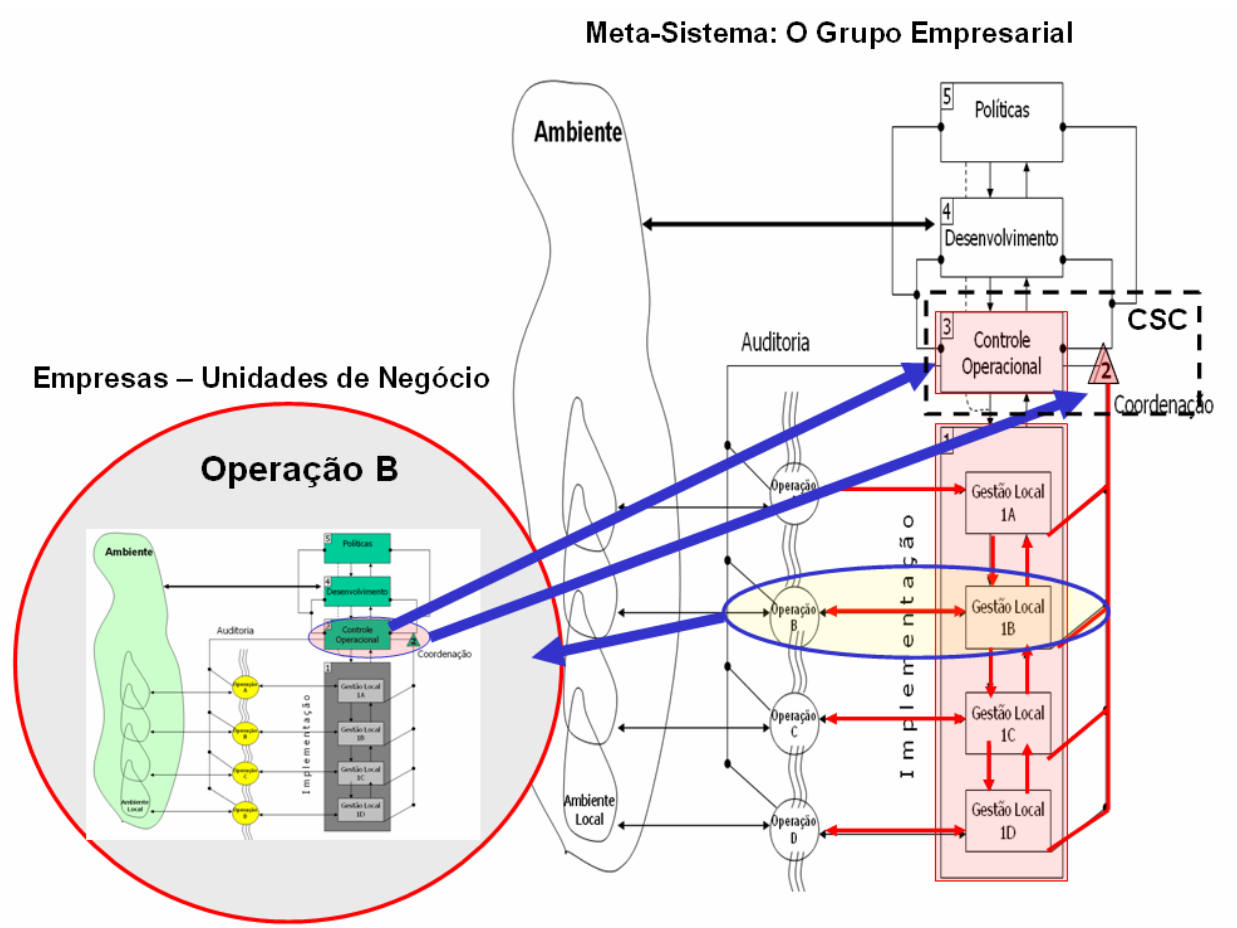

Figura 18 - Visão VSM indicando a reestruturação do grupo. A transferência de atribuições e variedades dos sistemas 1 (empresas e unidades de negócio) para o meta-sistema organizacional. As linhas e áreas em vermelho indicam o reforço em comunicação e controle que os sistemas 2 e 3 do meta-sistema supostamente adquirem através desta ação. A linha tracejada indica o âmbito de atuação do CSC dentro do modelo. 
A expectativa desta estratégia é a de obter resultados qualitativa e financeiramente superiores, já que o CSC é constituído de estruturas especializadas e específicas e as áreas de negócio passam a estar mais orientadas ao seu objetivo principal. Outro resultado esperado para esta estratégia é o de aumentar o nível de controle, coordenação e comunicação entre os sistemas 1, permitindo que o meta-sistema organizacional possa enxergar-se de forma integrada e sistêmica.

Cabe aqui uma observação importante: a redução do contingente humano promovido pela unificação das áreas administrativas poderia provocar um aumento de entropia no sistema considerando-se a hipótese de que o CSC fosse subdimensionado e o capital humano resultante não possuísse um conjunto de variedades internas necessárias ao combate da variedade do ambiente. Este cenário é razoável e potencialmente provável já que é muito comum que as estratégias corporativas, em momentos de crise, são orientadas para cortes em custos operacionais.

Outra constatação importante é o fortalecimento do sistema em nível 4, pela readequação da área financeira dentro do processo de planejamento financeiro e orçamentário que agora passa a estar sob um controle centralizado.

\subsection{O Planejamento estratégico e orçamentário}

Com a reestruturação, o processo de planejamento estratégico e orçamentário do grupo também sofreu profundas alterações. Até antes das transformações promovidas, os planejamentos estratégicos ocorriam de forma independente em cada uma das unidades de negócio, sem a realização de uma visão estratégica unificada para todo o grupo. Tampouco os planejamentos percorriam um processo estruturado e formal. Com a profissionalização da administração da empresa e a formação dos CSC, os processos de planejamento estratégico e orçamentário passaram a ser revistos para que proporcionassem uma visão única para o todo o grupo. 
Diante de restrições financeiras que o grupo vinha experimentando desde o final da década de 1990, entre os anos de 2000 e 2003, o planejamento estratégico da empresa resumiu-se quase que integralmente em estabelecer objetivos de redução de custos fixos e estabelecer uma base para posteriormente retomar o crescimento dos negócios do grupo. Face a estas restrições, foi também estabelecido um limite de capital para investimentos em projetos.

Após a reestruturação, a área de planejamento, subordinada à diretoria financeira do grupo, passou a ser o elemento centralizador do processo de planejamento estratégico e orçamentário. Ela passou a ser o elo entre a alta administração e as gestões de negócio e operações, coordenando o desenvolvimento dos orçamentos junto a todas as áreas de negócio do grupo. A área corporativa de planejamento do grupo passou, portanto, a assumir as seguintes responsabilidades:

- Divulgar os objetivos e as metas estratégicas para o desenvolvimento dos orçamentos em todas as áreas;

- Definir cronograma de elaboração do orçamento e suas revisões;

- Definir premissas econômicas para elaboração do orçamento;

- Analisar e revisar os orçamentos elaborados pelas unidades de negócio;

- Consolidar o orçamento do grupo e distribuí-lo;

- Efetuar o acompanhamento do orçamento, através de:

- Consolidação da documentação e relatórios de todas as áreas e unidades de negócio do grupo;

- Emissão periódica de relatórios de resultados.

Com a visão unificada proporcionada pela reestruturação do grupo, os orçamentos passaram a ser elaborados pelas áreas de negócio, áreas e departamentos e consolidados pela área de planejamento corporativa através de planilhas eletrônicas com dois horizontes orçamentários:

- Projeção para sete anos;

- Projeção para um ano - orçamento empresarial 
Após a divulgação dos objetivos estratégicos com as respectivas metas de negócio a serem alcançadas, as áreas, unidades de negócios e departamentos elaboravam seus orçamentos em duas componentes principais:

- Receitas e despesas;

- Investimentos / projetos.

Para auxiliar a elaboração dos orçamentos das áreas, eram produzidos dois grupos importantes de informações que auxiliam a formatar o orçamento:

Variáveis operacionais - Tratava-se de variáveis de representatividade no ciclo produtivo da organização. Elas serão subsídios no cálculo dos custos operacionais. Um dos principais insumos produtivos, por exemplo, possuía uma participação expressiva nos custos da empresa e o seu preço era dependente de condições do mercado mundial e de câmbio. Outras variáveis também eram consideradas, tais como despesas e custos fixos de áreas de como suprimentos, vendas e produção.

Premissas macro e micro econômicas - Obtidas através de consultorias especializadas. Cenários de mercados internos e externos, câmbio e principalmente informações, relacionados ao mercado de atuação da empresa, eram simulados e avaliados. Aspectos macroeconômicos, tais como inflação projetada, crescimento do PIB Produto Interno Bruto, também eram levados em consideração.

Além destas informações, políticas definidas pela organização do grupo deviam ser observadas no desenvolvimento dos orçamentos, a saber:

- Políticas de Caixa;

- Políticas de Crédito;

- Políticas de Investimento;

- Políticas de Pagamentos. 
A figura 19 ilustra os componentes que direcionam o processo orçamentário.

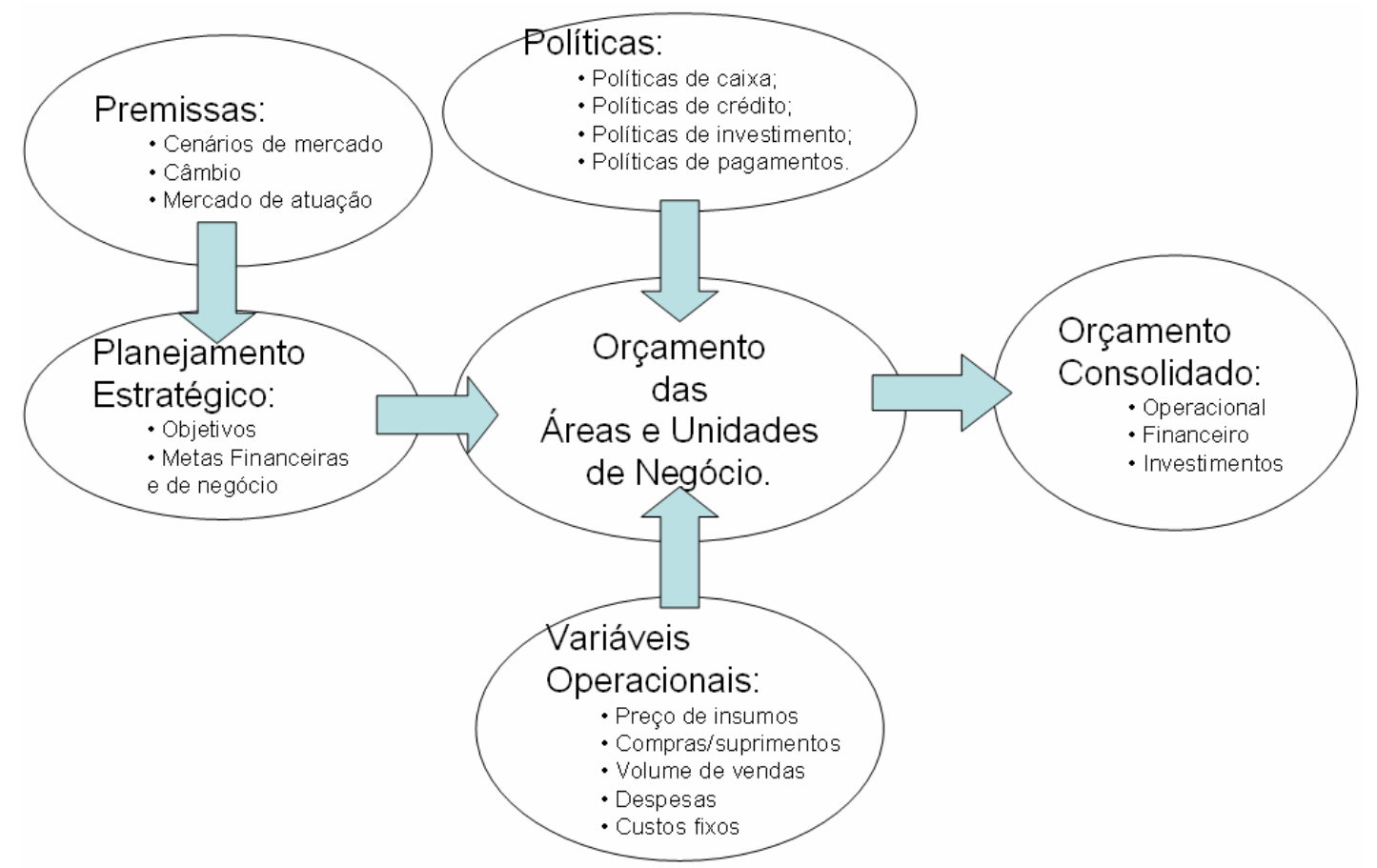

Figura 19 - Elementos de orientação do processo orçamentário.

\subsubsection{O Orçamento de investimentos}

As áreas e unidades de negócio possuíam autonomia limitada na aprovação de recursos para investimentos em projetos. Valores de médio porte podiam ser aprovados pela diretoria de uma área desde que, a mesma possuísse verba prevista em seu orçamento. Projetos acima desta faixa de valores deviam ser submetidos à aprovação pela alta direção do grupo e normalmente isso ocorria em tempo de planejamento orçamentário.

O processo de orçamento de investimentos, tal como observado nos modelos convencionais, ocorria pela a submissão das várias propostas de projetos à área de planejamento da diretoria financeira. As proposições de projetos eram encaminhadas para a área de corporativa de planejamento através de um padrão de planilhas de investimentos e fluxo de caixa, onde finalmente eram consolidadas para dar início a um processo de priorização e aprovação. 
As proposições eram então, submetidas a um comitê executivo formado pelas principais diretorias do grupo que avaliava, priorizava e aprovava as propostas submetidas ao processo orçamentário.

\subsubsection{Processos de priorização e aprovação de projetos}

Como normalmente a oferta de projetos oriundos das áreas era muito superior à capacidade financeira e de recursos humanos do grupo, a empresa precisava decidir quais proposições de projetos deviam ser aprovadas para que se obtivesse a melhor configuração de projetos dentro do porta-fólio corporativo. Sendo assim, o comitê executivo tinha a responsabilidade de avaliar os projetos propostos em termos de alinhamento com a estratégia, investimentos necessários, prazos para execução e, principalmente, o retorno financeiro que podiam proporcionar.

Este processo de priorização consistia basicamente da formação de uma lista de projetos priorizados pelas necessidades e estratégias da empresa. Para se definir esta priorização, planilhas eletrônicas eram utilizadas para registrar e calcular uma pontuação baseada em critérios de avaliação. A ordenação da lista por critérios específicos estabelecia a prioridade entre os projetos. De uma forma geral, os critérios de qualificação dos projetos se baseavam em indicadores de rentabilidade e volume de investimentos necessários, a saber:

- Fluxo de caixa descontado (Valor presente líquido);

- Taxa interna de retorno;

- Valor total de investimentos e despesas operacionais;

- Período de retorno do investimento (Payback).

Uma classificação secundária era feita para definir o caráter das propostas, que segmentava projetos entre:

- Manutenção;

- Aumento produtividade e/ou aumento funcionalidade;

- Crescimento em escala. 
O nível de criticidade de um projeto também era considerado através de duas possíveis classificações:

- Criticidade alta;

- Criticidade secundária.

De acordo com a rentabilidade, caráter e criticidade da proposta, o comitê executivo realizava a movimentação das propostas dentro da lista, priorizando os vários projetos.

As áreas de negócio e departamentos podiam ainda ser convidados a apresentar seus projetos pessoalmente, em uma sessão de explanação e argumentação dos objetivos a que se propõe um determinado projeto. Nestas seções, os gestores tinham a oportunidade de reforçar a sua argumentação para a aprovação dos seus projetos e o comitê executivo podia ou não revisar a posição das propostas na lista priorizada.

As proposições também podiam sofrer revisões, quer seja no escopo, em custos ou prazos, conforme solicitações do próprio comitê executivo, até que um projeto de interesse pudesse ser definitivamente aprovado ou ainda descartado.

Uma vez que as defesas, revisões e priorizações fossem consumadas e sendo o capital restrito para investimentos conhecido, o critério de corte para os projetos aprovados e não aprovados estabelecia-se pela soma dos investimentos dos mais prioritários até o valor estabelecido como limite de investimentos.

A figura 20 ilustra o método utilizado de lista priorizada de projetos, bem como o processo de definição de projetos aprovados de acordo com um ponto de corte pelo limite de investimentos. 


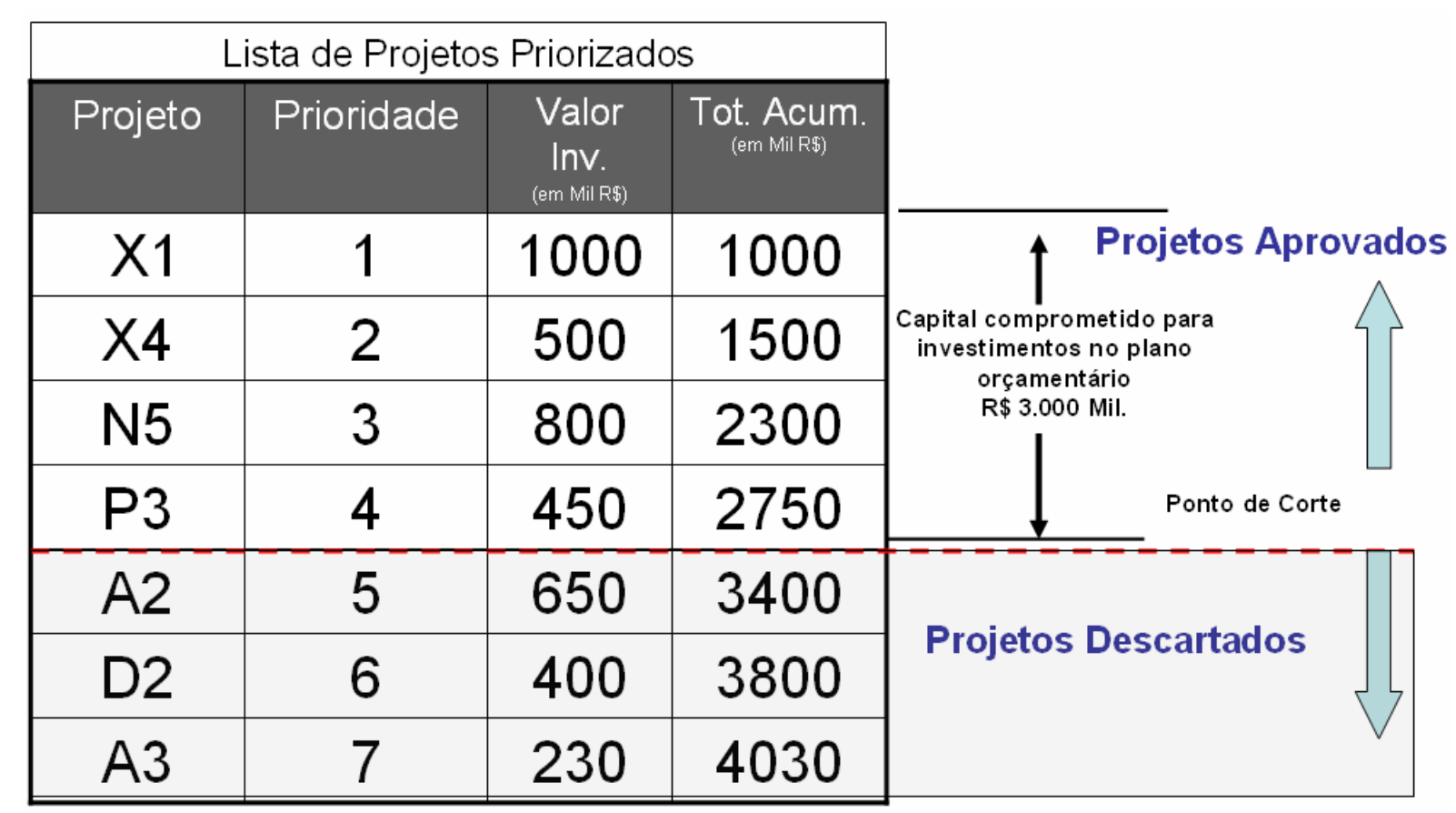

Figura 20 - Planilha de priorização de projetos do processo orçamentário. De acordo com a rentabilidade, caráter e criticidade da proposta, o comitê executivo realizava a movimentação das propostas dentro da lista, priorizando os vários projetos. A aprovação dos projetos estabelecia-se pela soma dos investimentos dos mais prioritários até o valor estabelecido como limite de investimentos.

Até ao ano de 2004, o processo de priorização de projetos no processo orçamentário ocorria de forma orientada a beneficiar proposições que promoviam redução de custos ou ainda daquelas que visavam manter a integridade operacional mínima da empresa. O volume financeiro destinado a projetos de inovação ou novos negócios era inexpressivo. Neste período, a priorização de projetos ocorria pela ordenação da lista pelo critério que estabelecia quantitativamente a redução de custos correspondente ao objetivo de um determinado projeto. Em geral, as proposições dividiam-se nas seguintes categorias:

- Reformas e manutenções de infra-estrutura predial e de produção;

- Terceirização de serviços;

- Automação de processos com redução de custos operacionais e fixos.

Mesmo em face às restrições orçamentárias impostas, o volume de proposições de projetos era bastante expressivo, ocorrendo a submissão em torno de cem a 
duzentas propostas por período orçamentário. A figura 21 ilustra uma síntese de como o processo orçamentário de investimentos ocorria neste período específico.

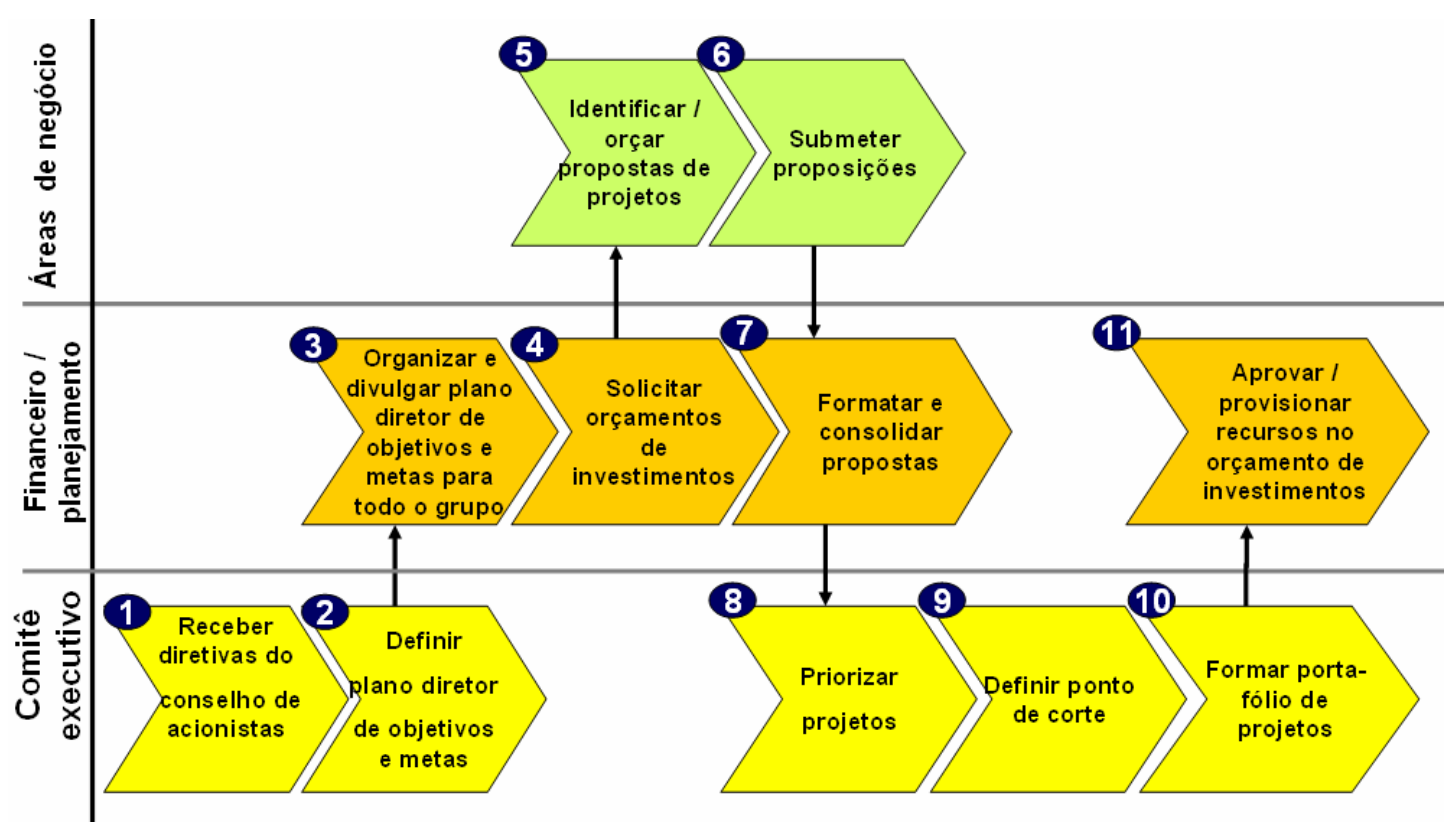

Figura 21 - Fluxo do processo orçamentário de investimentos. A coluna da esquerda indica as áreas envolvidas em cada um dos processos indicados pelas setas largas. A numeração dos processos indica a seqüência com a qual eles se estabelecem.

Ainda que estabelecido um processo formal e um cronograma de desenvolvimento, o processo orçamentário no componente de investimentos apresentava uma série de dificuldades, principalmente devido aos seguintes fatores, aos quais os gestores de áreas e unidades de negócios estavam sujeitos:

- Volume de demandas diárias concorrendo com a disponibilidade dos gestores;

- Dificuldades no entendimento das diretrizes estratégicas;

- Dificuldades de se traduzir propostas de projetos em um sumário executivo;

- Dificuldades no entendimento, desenvolvimento e padronização nas documentações a serem supridas.

Adicionalmente, o comitê executivo lidava também com a dificuldade de avaliar um volume considerável de propostas que, em boa parte, possuía fundamentos estratégicos questionáveis. 
Nessas condições, atrasos significativos na elaboração, aprovação e publicação dos orçamentos ocorriam sistematicamente. Em geral, o orçamento de um determinado período anual acabava sendo finalizado ao término do primeiro trimestre do ano da competência do mesmo.

Essa situação acentuou-se quando novas diretrizes estratégicas passaram a orientar os orçamentos, não só pela redução de despesas e custos fixos, mas também para a geração de receita através da introdução de novos produtos ou linhas de negócio. Como a empresa em questão opera em varejo, as proposições de projetos passaram a ter uma forte dependência com recursos de informação e tecnologia. Tal como as demais áreas e unidades de negócio ao longo do processo de reestruturação do grupo, a área de IT também sofreu uma grande reestruturação que desencadeou em uma série de problemas secundários, que tiveram de ser tratados através de uma nova abordagem na gestão de projetos de informação e tecnologia.

\section{$\Rightarrow$ Comentários e interpretação - Seção 5.4}

A estratégia de unificar as áreas administrativas do grupo através da formação do CSC criou um modelo centralizado de planejamento. Para a coordenação deste processo, uma área específica foi criada para administrar a variedade do processo de planejamento estratégico e orçamentário do grupo. Parte da variedade a ser administrada decorre das diferentes percepções à que uma estratégia está sujeita diante dos modelos de comunicação praticado em cada negócio ou processo do grupo.

Além do papel de coordenação do processo orçamentário corporativo junto às áreas envolvidas, a área de planejamento do CSC colhe também informações do ambiente interno (proposições das áreas de negócio e departamentos, diretivas estratégicas da alta direção corporativa) e do ambiente externo (premissas macro e micro econômicas) e as distribui estratificadamente, de acordo com a sua pertinência, aos consumidores de informação. Este comportamento indica a participação da área de 
planejamento nas competências dos sistemas 3 e 4, propostos pelo modelo de VSM. A figura 22 ilustra esse comportamento (seção 3.1.4).

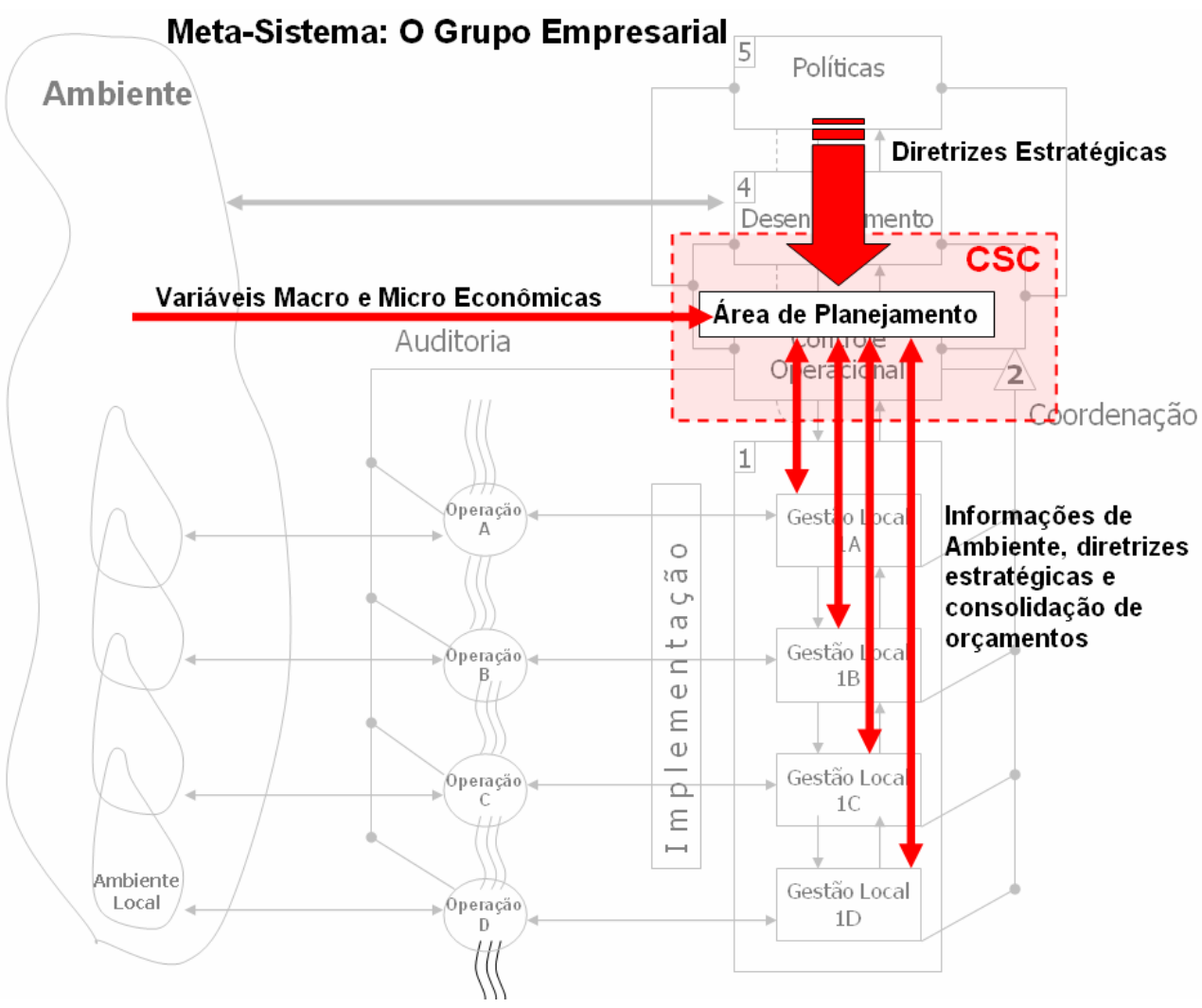

Figura 22 - Visão VSM indicando o âmbito de atuação da área corporativa de planejamento do CSC. As setas em vermelho indicam o fluxo de informações entre ambientes e hierarquias internas nos diversos sistemas (1, 4 e 5). A área em vermelho indica que as atribuições do CSC invadem competências esperadas pelo sistema 4, ou seja, o CSC exibe competências de captação e distribuição de informações do ambiente para a elaboração de um orçamento corporativo.

Verifica-se que o processo decisório, no que diz respeito à seleção de projetos, encontra-se centralizado em uma estrutura de alta hierarquia, denominada comitê executivo. A área de planejamento corporativo, sistema 4, captura todas as informações necessárias para a tomada de decisão de cunho estratégico e as entrega ao comitê executivo. Este comitê, responsável por prover a direção da empresa, pode ser classificado como um componente localizado no sistema 5 do VSM (seção 3.1.4), tal como ilustrado na figura 23.

Para a seleção de projetos, a tomada de decisão está sendo baseada essencialmente em critérios objetivos e quantitativos (seção 3.3.1.3), porém sob forte influência de aspectos subjetivos. Embora os indicadores de rentabilidade dos projetos norteiem a decisão, existe a evidência de que os projetos também estão 
sendo priorizados pela movimentação deles na lista de propostas pelo comitê executivo. Existe também um outro componente subjetivo uma vez que pode haver sessões de argumentações e defesas por parte das áreas de negócio; aos quais pode-se interferir na tomada de decisão pela argumentação do proponente de um projeto.

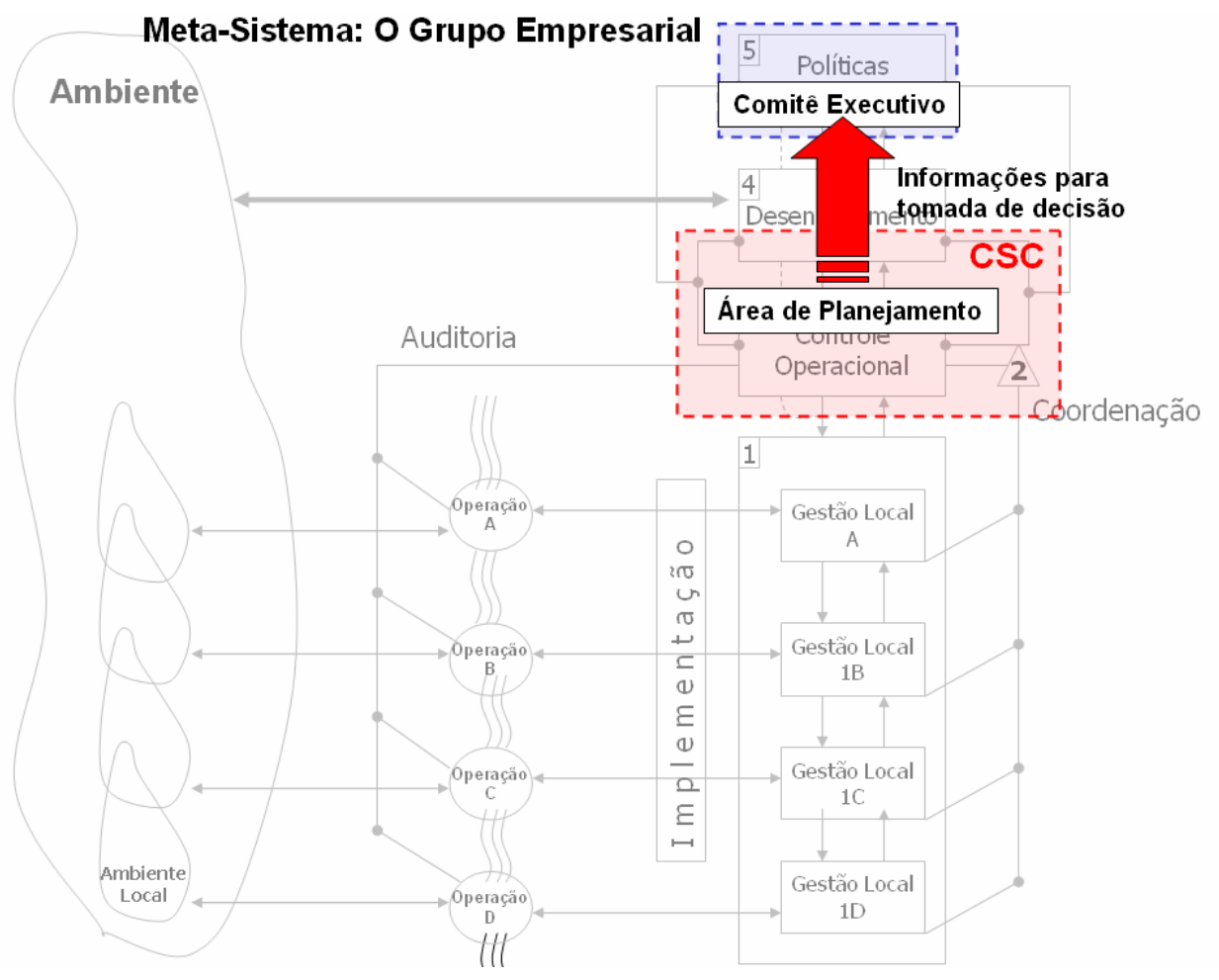

Figura 23 - Visão VSM indicando a atuação do comitê executivo do grupo na definição de um portafólio de projetos. O sistema 5, responsável por prover a direção da empresa, faz uso das informações consolidadas pelo sistema 4 (área de planejamento) através de um comitê executivo, que define os projetos que devem ou não ser aprovados.

Existe evidência da ausência de processos de qualificação preliminar ou filtro de proposições dentro do processo de priorização das propostas de projetos. Alguns autores sugerem que uma fase exploratória e de análise preliminar das proposições deve ser feita com intuito de evitar esforços em julgamentos mais elaborados, que demandam tempo e recursos, em proposições infundadas ou desalinhadas com as estratégias da organização (KERZNER, 2004; MEREDITH; MANTEL, 2000; KOYAMA; TASSEL, 1998) (seção 3.3.1.1): 
Com um modelo de filtro preliminar, o comitê executivo poderia efetuar análises e priorizações somente dos projetos que atendessem um conjunto mínimo de prérequisitos. Esta ausência justificaria parte das dificuldades enfrentadas pelo comitê executivo na avaliação e aprovação de um grande volume de propostas de projetos.

Não há também indícios de que a formação de um porta-fólio leve em conta um balanceamento de riscos e retorno global dos projetos, bem como interdependências entre proposições.

Existem evidências de falhas na comunicação das proposições de projetos. As dificuldades relatadas podem indicar três possibilidades:

- Excesso de variedade presente nos domínios das gerências de áreas de negócio - sistema 1;

- Competências específicas e mandatórias ausentes nos perfis gerenciais responsáveis pela elaboração de proposições de projetos.

- Ausência de apoio especializado no processo.

Cabe aqui uma analogia entre os padrões de comunicação experimentados por uma organização e a variedade a ser administrada. Os canais de comunicação, dentro dos diversos níveis e estruturas organizacionais, estão dimensionados para estabelecerem modelos especializados de informação. Esses canais podem, portanto, processar informações de acordo com a percepção de variedade a que um determinado subsistema está preparado para responder. Desta forma, pode-se inferir que as diferentes percepções e interpretações, a que uma estratégia corporativa está sujeita, são também decorrentes da transformação da informação, que flui entre as diversas unidades de uma organização, sob a perspectiva da variedade que uma determinada área está orientada ou especializada. Pode-se, portanto, distorcer o conteúdo de uma mensagem que flui entre as várias hierarquias e ou disciplinas de uma organização.

Ainda em relação a essas dificuldades apontadas, verifica-se que se enquadram nos padrões identificados na bibliografia pesquisada (MOORE, 1999; RASMUSSEN et 
al., 2003; NEELY; SUTCLIFF; HEYNS, 2001; LORANGE, 1982). Esses autores apontam que, em geral, os processos de planejamento orçamentário defrontam-se com dificuldades principalmente pelos seguintes motivos:

- Pouco conhecimento dos envolvidos em relação à sua importância dentro de um planejamento estratégico;

- Concorrência das atividades do processo com as atividades operacionais dos envolvidos;

- Quase sempre ocorre sem à devida orientação aos envolvidos;

- Carência de conhecimentos de técnicas, métodos e padrões necessários ao processo;

- Distorção da visão estratégica devido às diferentes percepções humanas à que está sujeita.

Uma outra observação interessante diz respeito ao estado anterior (à reestruturação do grupo) do processo de planejamento do grupo. Sendo descentralizado, criava-se um risco potencial de que algumas das unidades de negócio assumissem um comportamento autopoiético $^{16}$, ou seja, passarem a atuar sob uma autonomia total nas suas decisões estratégicas que poderiam não corresponder às necessidades gerais da organização do grupo.

\subsection{Reestruturação da área de IT}

Antes da implementação do CSC, tal como as demais áreas de apoio, o grupo possuía cinco áreas independentes de IT, orientadas a trabalhos de produção, operação e desenvolvimento de infra-estruturas e sistemas de informação, atendendo desde demandas de negócio até administrativas.

\footnotetext{
16 Tal como apresentado na seção 3.1.4, novamente, no trecho acima a intenção não é a de indicar a autopoiese como um comportamento indesejado para os organismos vivos ou para uma organização social. A citação acima remete à hipótese da autopoiese se manifestar em uma subparte de um organismo, porém em um comportamento cuja autonomia é dissonante com as necessidades das demais partes do sistema onde ela se relaciona.
} 
Com a introdução do modelo de CSC, as áreas mencionadas foram unificadas em uma única entidade corporativa. Em um momento inicial, o contingente humano foi reduzido pela metade pela própria redundância em atividades de apoio e suporte.

Um fenômeno verificado em decorrência desta transformação foi a transição de ambientes com plataformas e tecnologias de caráter homogêneo para um novo modelo com caráter heterogêneo, ou seja, múltiplos conceitos de infra-estruturas e sistemas passaram a ser administrados em um ambiente comum. Isto foi decorrente do fato de que, antes da reestruturação, cada uma das áreas de IT definia sua própria estratégia de abordagem técnica.

A redução de contingente humano na área de IT também trouxe a perda sistemática de conhecimentos técnicos e de negócio específicos. Muitas das áreas originais atuavam de forma precária e informal, sem nenhum tipo de metodologia ou cuidados em manter atualizadas documentações dos sistemas de software e processos. A falta de padronização e as ambigüidades observadas nas atribuições dos profissionais técnicos das áreas originais, seguidas dos desligamentos efetuados, contribuíram em especial para esta perda.

Este conjunto de fatores provocou uma série de dificuldades técnicas e administrativas para a nova área corporativa de IT, principalmente porque a arquitetura resultante apresentava uma grande complexidade de infra-estrutura, sistemas e necessidades de manutenção e desenvolvimento. A arquitetura resultante também demandava um corpo técnico extremamente diversificado na medida em que as tecnologias a serem mantidas e os negócios a serem atendidos formavam um grande conjunto de temas técnicos a serem dominados.

Diante das dificuldades resultantes da unificação das áreas e da diretiva estratégica do grupo em reduzir custos fixos, a nova administração corporativa da área de IT, desenvolveu um plano de mudanças que, em síntese, buscaram:

- Redefinição de papéis e responsabilidades da área dentro da organização;

- Definição de um novo organograma interno; 
- Terceirização de serviços técnicos especializados principalmente em:

- Infra-estrutura;

- Serviços de suporte e atendimento ao usuário;

- Manutenção e desenvolvimento de sistemas.

- Substituição dos sistemas desenvolvidos internamente por soluções padrão de mercado.

Os objetivos desta transformação eram evitar a necessidade de manter um corpo técnico extenso e heterogêneo que impunha um alto custo fixo, transferindo a responsabilidade da gestão operacional do parque tecnológico para terceiros especializados. Desta forma, a área de IT passaria a manter foco na inteligência da gestão de parceiros e fornecedores, bem como na gestão dos projetos demandados internamente pelo grupo. Ao final desta segunda reestruturação, a área corporativa de IT ficou reduzida a um total de trinta funcionários.

\subsubsection{Gestão de projetos da área de IT}

A reestruturação geral do grupo promoveu internamente uma grande demanda de desenvolvimentos e manutenções em sistemas que suportavam os negócios e a administração do grupo. Isto devido às novas necessidades dos negócios da empresa e das mudanças em processos que, em síntese, significavam necessidades de implementações e transformações nos sistemas que atendiam as áreas clientes.

Neste período, observava-se uma total ausência de formalismo no encaminhamento de solicitações, bem como de proposições e execução de projetos, tanto das áreas clientes como da própria área de IT. Até então, as práticas resumiam-se em dinâmicas informais através de interações verbais com algum representante técnico da área IT, normalmente alguém com quem a área mantinha algum relacionamento em função de necessidades quotidianas. Os levantamentos e detalhamentos promovidos pelos técnicos responsáveis, necessários ao encaminhamento dos projetos, também ocorriam de forma informal e desestruturada. 
Em decorrência deste padrão, observava-se uma série problemas e dificuldades na condução de projetos que envolviam tecnologias de informação:

- Projetos iniciados sem nenhum tipo de formalização interna;

- Escassez de recursos diante de necessidades concorrentes ou não programadas;

- Dificuldades de transcrição de escopo do projeto de forma objetiva e precisa;

- Freqüentes alterações do escopo inicial acordado;

- Prazos e custos orçados não refletiam a realidade e necessidades de um projeto;

- Ausência de processos estruturados de planejamento e controle dos projetos em execução;

- Cancelamento de projetos devido à indisponibilidade de recursos financeiros não programados ou por uma inviabilidade técnica não observada;

- Constantes conflitos entre as áreas usuárias e a área de IT.

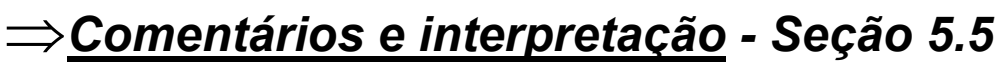

Tal como na reestruturação das demais áreas da empresa, a área de informação e tecnologia sofre uma unificação que remove a variedade dos sistemas 1 dentro do meta-sistema organizacional. A nova área corporativa de IT, em um primeiro momento, é submetida a um excesso de variedade a ser controlado devido, principalmente, aos seguintes fatores:

- Aumento nas disciplinas técnicas a serem dominadas, que produz aumento na variedade a ser controlada;

- Aumento no número de áreas clientes a serem atendidas, que produz aumento na variedade a ser controlada;

- Aumento na complexidade da arquitetura de tecnologia resultante da unificação, que produz aumento na variedade a ser controlada; 
- Redução no contingente humano responsável pelas atividades técnicas e administrativas, que reduz sua variedade interna;

- Perda de conhecimentos específicos devido aos desligamentos, que reduz sua variedade interna.

Como ação de resposta a esse aumento de entropia interna, a decisão da área corporativa de IT corresponde, na Cibernética, à ação de reduzir as variedades a serem controladas através da transferência destas para sistemas especialistas externos ao meta-sistema organizacional. Esta ação de resposta é viabilizada por processos de terceirização de serviços na área de infra-estrutura, manutenção e desenvolvimento. Com esta ação, a área de IT consegue também responder à diretiva estratégica de redução de custos fixos, já que pode dispor de parte de recursos humanos responsáveis por atividades que agora são desempenhadas por terceiros. Ao mesmo tempo, a decisão da área em direcionar o foco das competências humanas para atividades de administração e controle corresponde ao efeito de mudar o escopo de suas variedades internas, já que a característica das variedades a serem administradas mudou.

Ainda assim, a área possui responsabilidades no nível operacional, já que deve manter as infra-estruturas e sistemas que suportam o nível 1 do meta-sistema organizacional. Essas atividades devem ser desempenhadas por recursos internos que supervisionam se as necessidades das operações nas áreas clientes estão sendo atendidas e atuam para que se ativem regimes de auto-regulação, caso o terceiro não esteja respondendo de acordo com o esperado. Este ciclo homeostático é característico de sistemas onde existem necessidades a serem supridas para que se garanta a sobrevivência do sistema (Flood, 2002) (seção 3.1.1). A figura 24 ilustra a interpretação destas considerações.

Em relação à grande demanda por manutenções e desenvolvimentos nos sistemas de software do grupo, pode-se concluir que a reestruturação geral do grupo promoveu um ciclo de homeostase em cada uma das áreas e departamentos do meta-sistema organizacional. Como parte deste ciclo de reorganização e autoregulação, as áreas de negócio necessitaram ajustar suas variedades internas e isto 
dependia também de ajustes em subsistemas que promoviam o processamento das informações necessárias ao controle das variedades administradas por essas áreas.

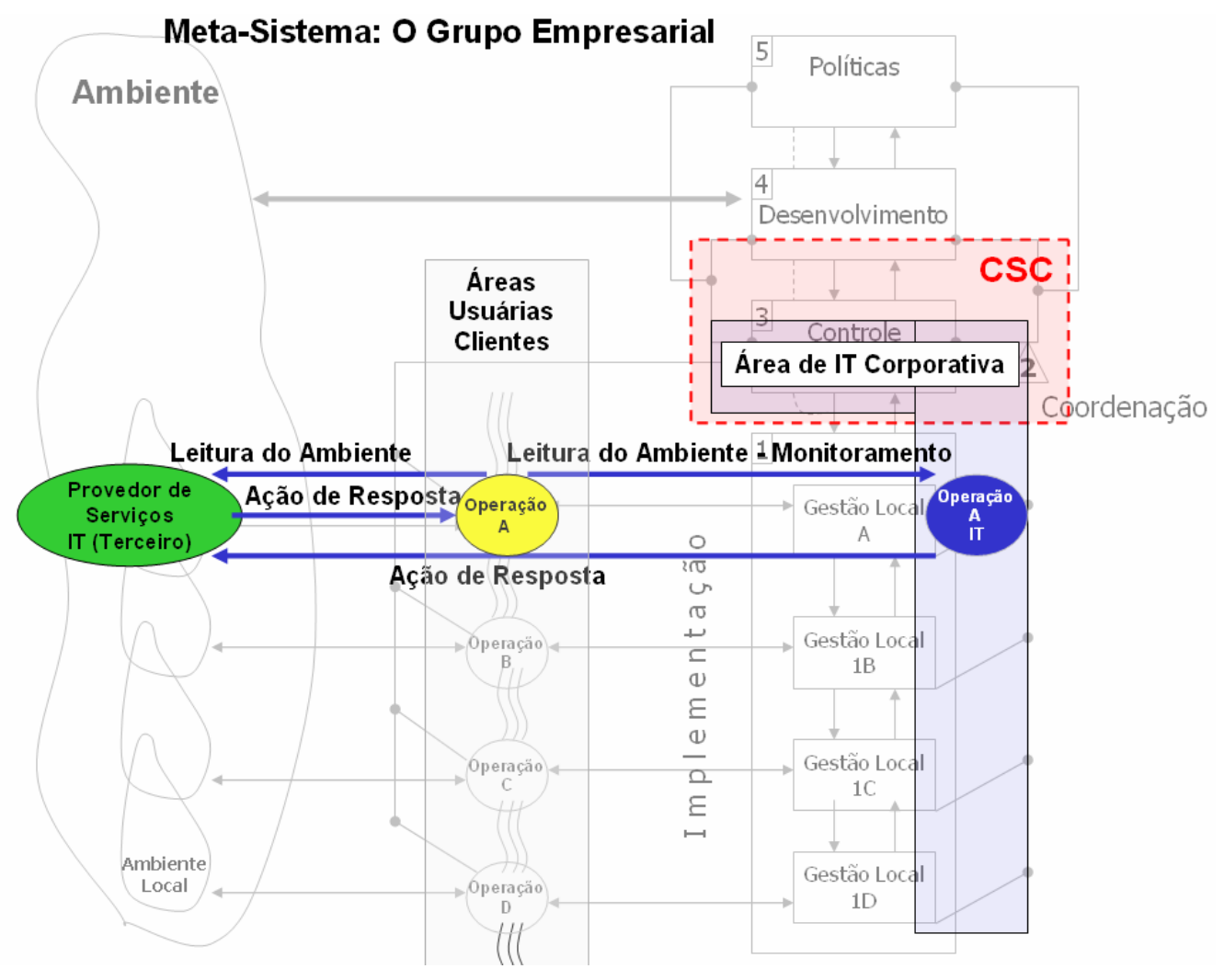

Figura 24 - Visão VSM indicando a atuação da nova área corporativa de IT em azul. A área em vermelho representa o posicionamento do CSC dentro do VSM. A terceirização de serviços especializados é indicada na área externa ao meta-sistema organizacional, já que agora a variedade a ser controlada nas operações é desempenhada por um fornecedor externo. A ação de leitura do ambiente desempenhada pela operação de IT é necessária para validar se o sistema fornecedor, externo ao meta-sistema organizacional, está desempenhando suas funções adequadamente.

Neste contexto, os subsistemas correspondem ao ferramental tecnológico, em que incluem-se os de sistemas de software que precisam ser readequados para que se atenda um novo conjunto de variedades a serem administradas. Neste ponto, estabelece-se a dependência entre as áreas clientes e uma área especialista, neste caso, a de IT.

Uma consideração interessante é a de que este cenário revela-se como um exemplo que ilustra a característica orgânica de um sistema organizacional. As ações de homeostase das áreas de negócio e departamentos, desencadeadas pelo processo de reestruturação, criaram um aumento secundário de entropia que se manifestou na área de IT pelo excesso de demandas por mudanças em sistemas de software. 
Dependendo da complexidade e volume de variedades a serem tratadas, as mudanças promovidas nos sistemas de software devem ocorrer através de um modelo estruturado e coordenado, sem o qual o sistema gera entropia além de um limite viável, comprometendo o resultado final da proposta de homeostase ${ }^{17}$. Uma das formas de se promover isso é através de técnicas presentes na gestão de projetos (PMI, 2004, KERZNER, 2001, 2004; KENDALL; ROLLINS, 2003; CLELAND, 1999).

Por outro lado, a ausência de formalismo e estruturação nos processos de encaminhamentos de projetos dentro do meta-sistema organizacional geram uma série de dificuldades e problemas e são uma evidência, constatada aqui pelas as seguintes razões:

- Ausência de variedade interna relativa às competências necessárias à gestão profissional de projetos;

- Carências no modelo de comunicação;

- Carências no modelo de controle.

De fato, na literatura especializada, é notória a preocupação das organizações em relação ao desempenho e resultados finais de projetos empreendidos (seção 3.4). Os problemas evidenciados no estudo de caso são comuns e se enquadram nas estatísticas que tratam do desempenho de projetos (STANDISH GROUP, 1994).

A gestão de projetos pode ser ilustrada no VSM considerando-se a ênfase em comunicação e controle, necessários principalmente em ambientes que refletem a metáfora neuro-cibernética, que é compatível com ambientes de projetos, pois trata principalmente de situações onde encontramos (seção 3.1.1):

- Sistemas orientados a objetivos e aprendizado;

- Ambientes com um alto grau de incerteza;

- Necessidade de inovação e criatividade.

\footnotetext{
${ }^{17}$ Esta metáfora corresponde à viabilidade técnica e financeira que um projeto deve atender.
} 
Pode-se enquadrar o sistemas 1 como efetivamente os produtores das partes que compõem os produtos do projeto. A gestão do projeto situa-se nos sistemas 2, 3, através de processos de coordenação e controle, e em parte do sistema 4, já que esta deve também colher e prover informações do desempenho global do projeto e informações do ambiente para identificar ameaças e oportunidades. Outra parte do sistema 4 corresponde às funções que definem o escopo conceitual do projeto entre as várias possibilidades de satisfazer às necessidades do demandante do projeto, que em uma hipótese provável estaria no sistema 5, já que este define o objetivo maior do meta-sistema projeto. A figura 25 ilustra esta interpretação.

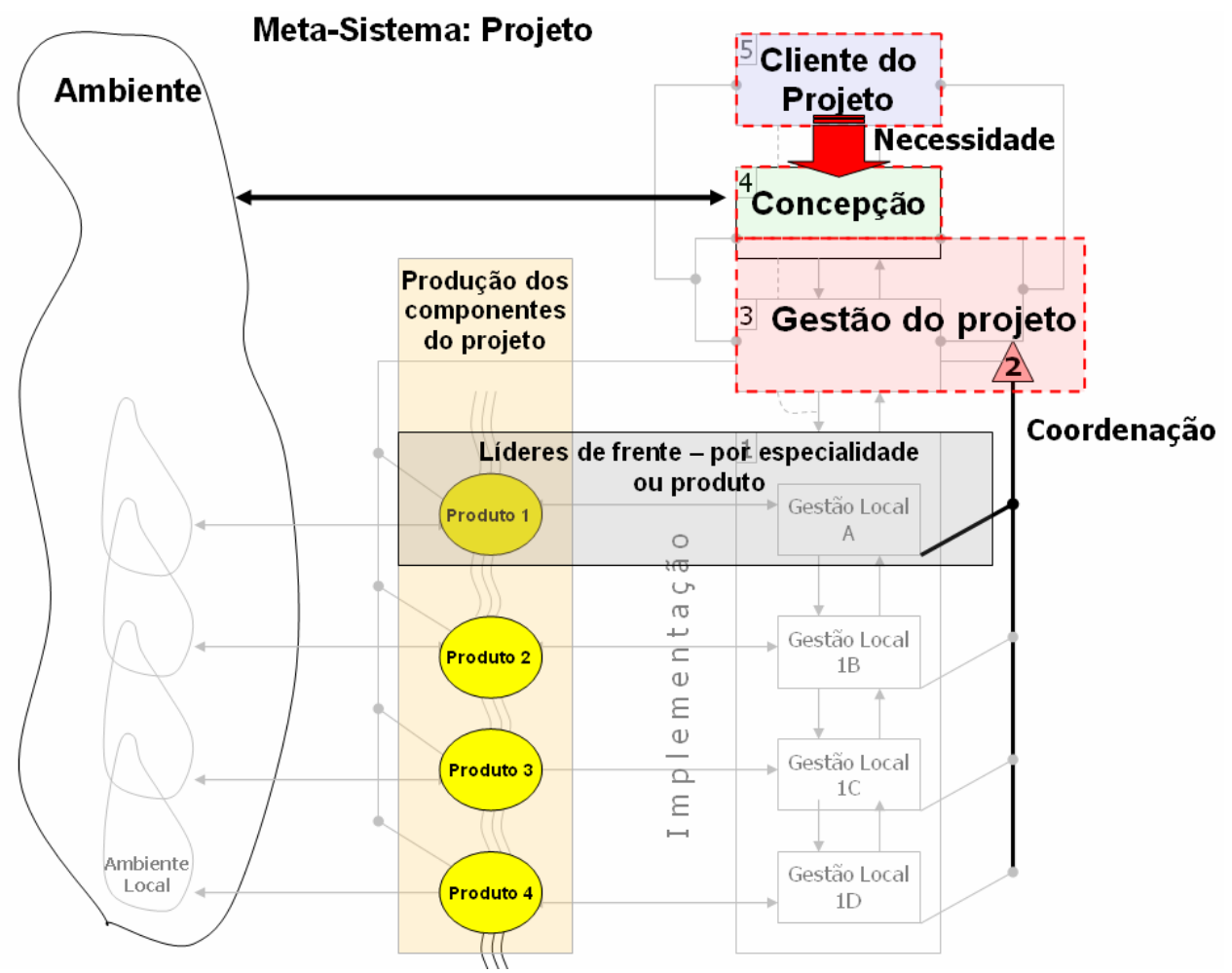

Figura 25 - Visão VSM para um meta-sistema projeto. O cliente do projeto, sistema 5, define a necessidade e, portanto a direção, as metas e objetivos a serem alcançados através da implementação do projeto. A concepção de um escopo conceitual ocorre no sistema 4. Este captura informações do ambiente interno e externo, avalia as possibilidades de atender às necessidades do sistema 5 e estabelece o conceito de solução que deve orientar o detalhamento de um escopo a ser cumprido. A gestão do projeto também participa do sistema 4, já que colhe também informações do ambiente na forma de métricas de desempenho, variações no ambiente do projeto, necessidades e riscos, e as distribui, conforme a pertinência. Os sistemas 2 e 3 respondem pelas principais atividades da gestão do projeto, que estabelece um regime de coordenação em cada uma das frentes, representadas pelos sistemas 1.

No modelo de VSM, são realçadas as necessidades de visão sistêmica e harmônica da gestão, principalmente na execução do projeto, uma vez que as partes 
componentes de um produto devem ser integradas e entregadas dentro de uma disponibilidade de recursos, eficiência financeira e em uma restrição de escopo, custos e prazo. No contexto da gestão de projetos, reforçam-se, portanto, os componentes de comunicação e controle que devem estar sendo desempenhados de forma padronizada e precisa, pois deve-se orientar cada uma das partes do sistema 1 para que se ativem as ações adequadas de homeostase sempre que o meta-sistema projeto não responder dentro do desejado.

\subsection{Criação do EGP na área de IT}

Diante das circunstâncias verificadas, a administração da área de IT estabeleceu um programa interno de profissionalização com objetivo de amadurecer a capacitação da área na gestão de projetos. Como resultado desta iniciativa, a área criou uma central de projetos, com as responsabilidades de um EGP. Três principais ações foram implementadas para a constituição deste EGP:

- Treinamento, capacitação e contratação de profissionais em gerência de projetos - Profissionais internos ou contratados foram selecionados e, após treinamentos específicos, passaram a assumir o papel de gerentes de projetos.

- Desenvolvimento de metodologia interna para a gestão dos projetos da área de IT - Para suportar as práticas de gestão de projetos, um trabalho interno de padronização de processos e documentação foi desenvolvido com a meta de se desenvolver uma metodologia própria de gestão de projetos.

- Modelo de relacionamento com área cliente ${ }^{18}$ - A ação tomada foi a de estabelecer um modelo formal de comunicação entre áreas clientes e a área de IT através de gerentes de projetos dedicados por linha de negócio, assumindo as seguintes responsabilidades:

\footnotetext{
${ }^{18}$ Entende-se aqui como área cliente, os clientes internos da área de informação e tecnologia que correspondem às diversas áreas, departamentos e unidades de negócio que compõem o grupo.
} 
- Atender e encaminhar as demandas diárias de manutenção e produção dos sistemas de tecnologia de informação que suportam os negócios das áreas de sua responsabilidade;

- Estabelecer e manter relacionamento formal junto à área de negócio através da interação diária com os gestores da área e em reuniões formais e periódicas;

- Estabelecer e manter relacionamento formal junto aos fornecedores terceiros que provêem serviços especializados de infra-estrutura e desenvolvimento de soluções de informação e tecnologia;

- Endereçar formalmente, na forma de projetos, demandas das áreas para novas necessidades de negócio, desenvolvimentos e melhorias de sistemas e processos;

- Gerenciar os Projetos formalmente autorizados dentro de sua área de negócio.

A figura 26 ilustra o organograma do EGP implementado, apresentando principalmente a estrutura matricial de atendimento das áreas clientes pelos profissionais dedicados a cada linha de negócio do grupo.

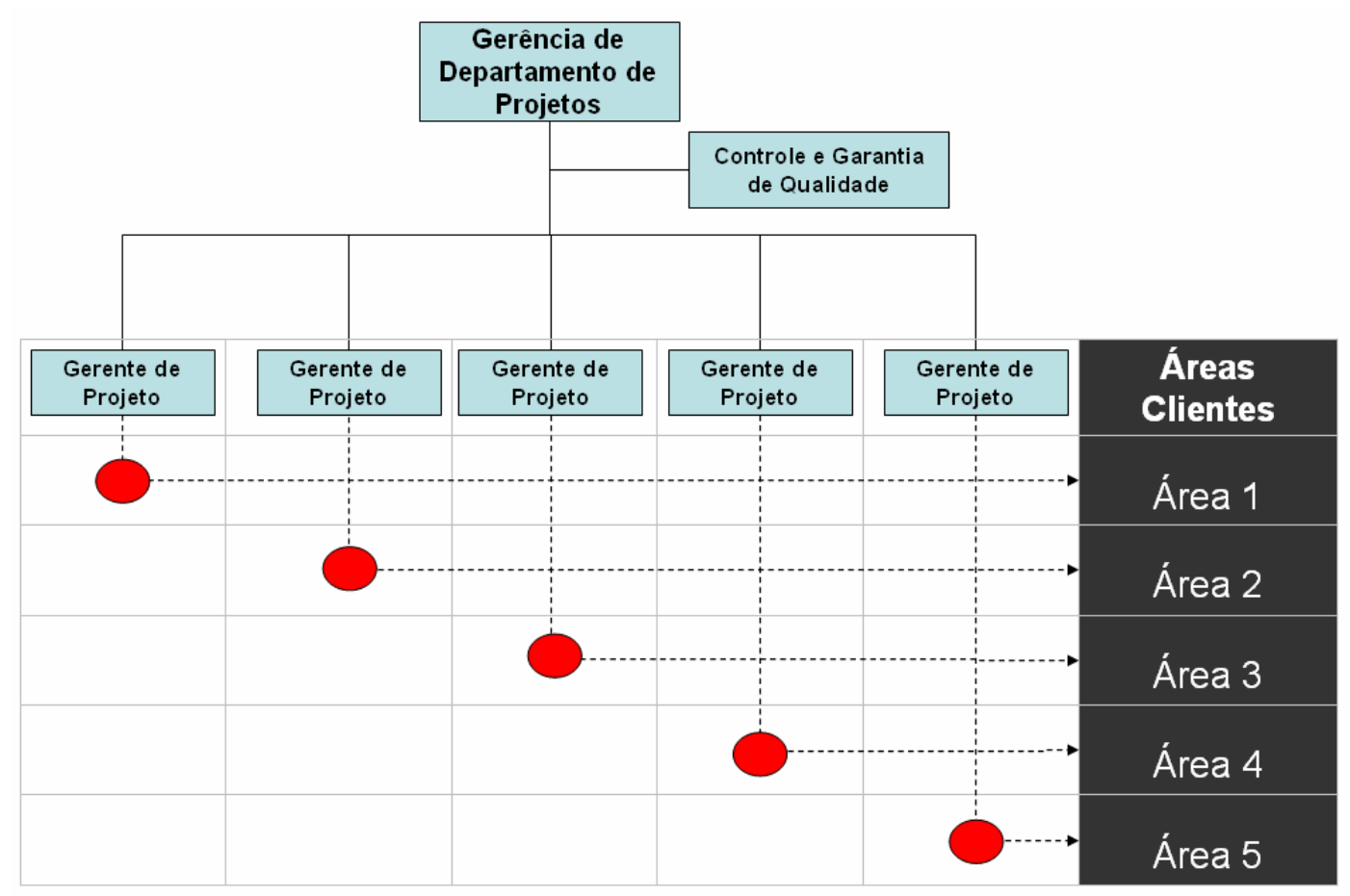

Figura 26 - Organograma do EGP implementado pela área de IT. 
Para o desenvolvimento de uma metodologia de gestão de projetos, o EGP orientouse pela estruturação de processos que garantissem os seguintes requisitos no encaminhamento dos projetos da área:

- Estudo preliminar de viabilidade técnica e econômica de qualquer proposição a projeto;

- Aprovação formal dos projetos dentro da organização, com visibilidade inclusive na área financeira;

- Entendimento e detalhamento estruturado do escopo do projeto;

- Planejamento detalhado de cronograma e desembolsos financeiros;

- Modelo estruturado e periódico de controle e acompanhamento dos projetos;

- Gestão da mudança para requisitos de escopo.

Como resultado, um modelo de gestão em seis fases principais foi criado. $O$ diagrama da figura 27 ilustra a metodologia desenvolvida.

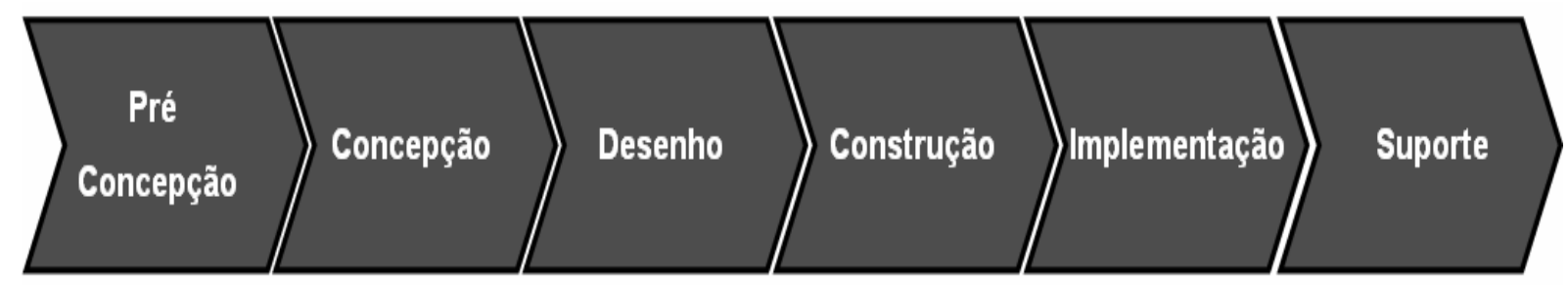

Figura 27 - Fases de um projeto na metodologia de gestão de projetos desenvolvida pela área de informação e tecnologia.

As seis fases da metodologia são descritas a seguir:

- Fase de pré-concepção - Promove um entendimento da demanda junto ao solicitante, com a formatação de um escopo preliminar, estudo de viabilidade técnica e econômica, desenvolvimento de um cronograma e programa de desembolsos financeiro em caráter de estimativa. O principal produto desta fase é a aprovação ou não de uma proposição de projeto, através de um documento de sumário executivo;

- Fase de concepção - Uma vez aprovada a pré-concepção, a proposta deve ser refinada e detalhada em um escopo, plano de 
custos e cronograma de execução e entrega. Novamente, o produto desta fase é submetido a uma aprovação formal para liberação / alocação de recursos humanos e financeiros para a execução e entrega do projeto;

- Fase de desenho - Contempla o detalhamento de desenhos de processos, protótipos e sistemas e subsistemas a serem produzidos com posterior aprovação pela área demandante do projeto;

- Fase de construção - Produção propriamente dita do escopo definido pela fase de concepção e desenho;

- Fase de implementação - Consiste da entrega e entrada em produção dos produtos gerados pela fase de construção. Ocorre a homologação pela área cliente, consistindo de um aceite formal do projeto;

- Fase de suporte pós implantação - Período de suporte pós implantação que tem por objetivo garantir ajustes necessários em decorrência de problemas não detectados na fase de implementação.

Ainda que resultante de um trabalho interno da área corporativa de IT, a nova metodologia cria uma séria de conflitos e resistências internas. A princípio, os esforços empenhados nos processo de preparação e planejamento, antes do início da execução de um projeto, se contrapunham às práticas anteriores, caracterizadas pela total ausência de formalismo e planejamento.

Adicionalmente, as áreas clientes também manifestaram resistências uma vez que o formalismo do processo foi interpretado como um excesso de rigor e burocracia. A metodologia criada impunha uma necessidade de maior empenho e disponibilidade de tempo das áreas clientes junto à de IT. O desenvolvimento das documentações, principalmente de escopo, exigia várias interações estruturadas e recorrentes junto ao solicitante do projeto e este, muitas vezes, não se dispunha a investir tempo nesta etapa.

Um outro fator de conflito, junto às áreas clientes, foi devido à introdução de um estudo mais elaborado de viabilidade técnica e econômica das propostas de 
projetos. As estimativas de custos e prazos passaram a ser mais realistas, trazendo um desconforto em relação às expectativas iniciais das áreas demandantes.

A superação destes entraves envolveu um trabalho forte de persistência e aculturação tanto da área de IT quanto das áreas clientes. Porém, o fator determinante para a sedimentação do novo modelo foi a superioridade de qualidade das informações geradas em uma fase de pré-concepção de um projeto, que permitiu uma melhora substancial no desempenho e resultados dos projetos que envolviam informação e tecnologia.

O modelo de relatórios de desempenho e evolução dos projetos junto às gerencias e diretorias de áreas clientes também contribuíram para o fortalecimento das novas práticas uma vez que os administradores passaram a ter maior visibilidade e controle de seus projetos.

Um outro problema secundário verificado foi devido ao grande volume de demandas das áreas cliente, a serem submetidas a uma fase de pré-concepção. A documentação preliminar gerada em uma fase pré-concepção exigia um esforço, em média, de três a cinco dias para o desenvolvimento conjunto entre um gestor de projetos e a sua área cliente.

Verificou-se também que as solicitações de orçamento de projetos deveriam sofrer uma avaliação preliminar antes de se iniciar uma etapa de pré-concepção. Em um dado período orçamentário, por exemplo, após a submissão de várias proposições envolvendo tecnologia da informação, verificou-se posteriormente que grande parte das propostas possuía as seguintes características:

- Propostas referentes a manutenções corretivas de sistemas. Ou seja, poderiam ser tratadas por um chamado técnico;

- Propostas referentes a pequenas implementações evolutivas em sistemas cuja alçada de aprovação encontrava-se no domínio da área de negócio;

- Propostas referentes a implementação de funcionalidades já disponíveis em sistemas em uso pela área. 
Neste universo, observaram-se também situações onde um conjunto independente de proposições, que a princípio não guardavam relação, poderia ser abordado em uma única pré-concepção de um projeto maior.

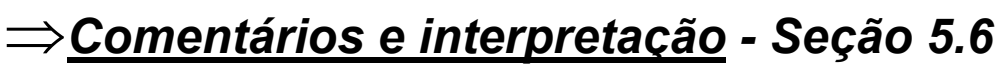

Como resposta à ausência de habilidades na disciplina de gestão de projetos, a área corporativa de IT opta por uma estratégia que corresponde a aumentar a variedade interna de suas partes designadas a implementar projetos. Uma constatação importante é a de enxergar o princípio da homeostase, agindo, neste caso em específico, pela importação de entropia negativa, na forma de conhecimento estruturado em gestão de projetos $^{19}$ (Seção 3.1.2).

Em sistemas abertos, elementos de auto-regulação e adaptação dão-se pela importação de entropia negativa para que se contraponha à desordem verificada internamente. Os treinamentos e capacitações específicos no assunto fazem o papel de trazer o conhecimento de fora para dentro do meta-sistema organizacional e de, portanto, reduzir a entropia ou desordem verificada internamente.

A estratégia de organizar este conjunto novo de variedades internas em uma estrutura especializada denominada EGP pode também ser vista como uma recursividade do VSM em uma dimensão acima da gestão de projetos. Neste caso, a intenção é a de se manter uma comunicação e controle padronizado em cada uma das partes designadas a implementar projetos e, por conseqüência, em cada um dos projetos sob a hierarquia do meta-sistema EGP. A figura 28 ilustra a visão VSM para o EGP.

\footnotetext{
${ }^{19}$ A informação é uma medida de ordem ou organização que pode ser caracteriza como uma entropia negativa (BERTALANFFY, 1979).
} 


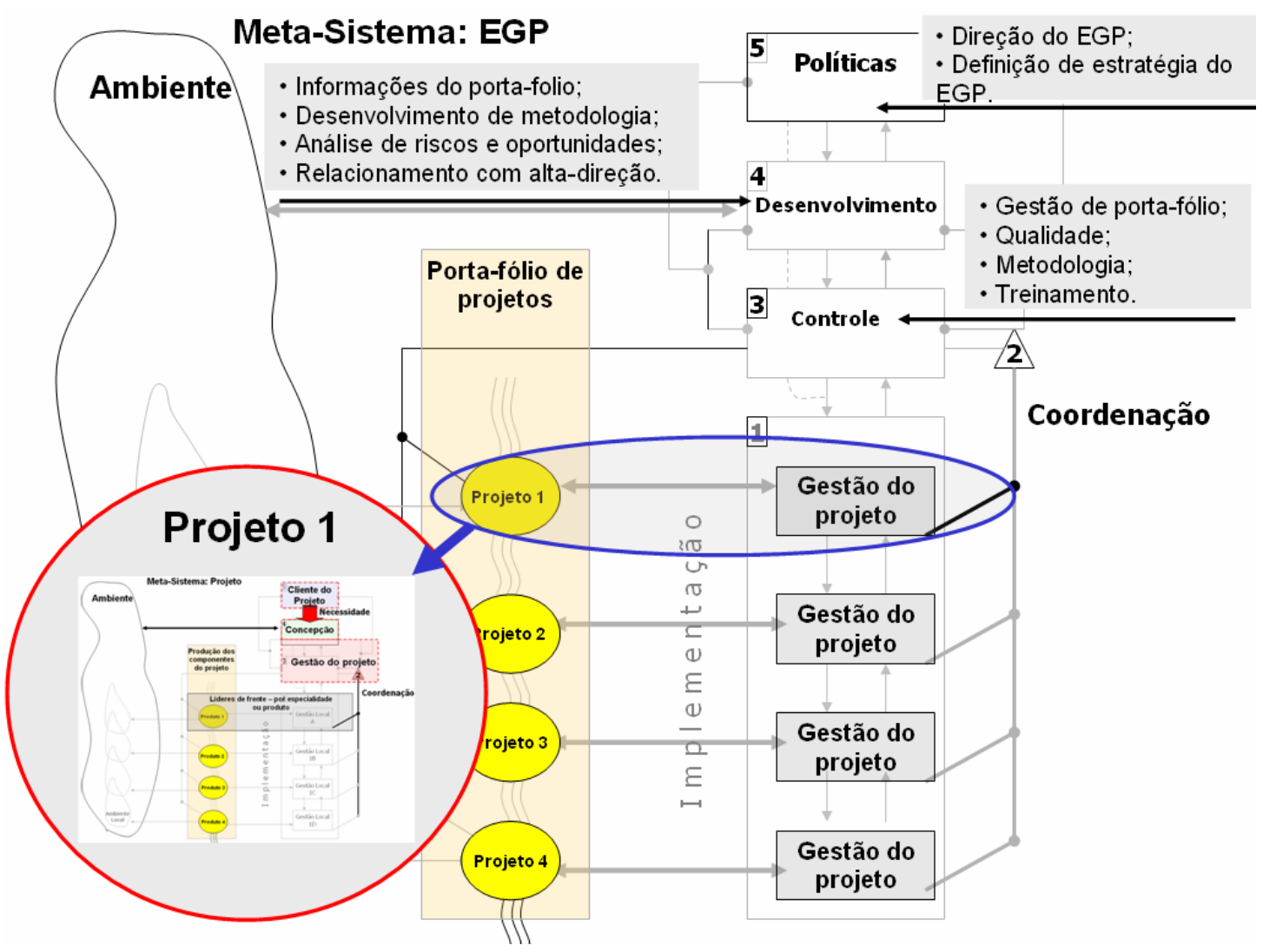

Figura 28 - Visão VSM para o EGP. A recursividade do modelo é aproveitada nos sistemas 1, representando a estrutura do VSM para o meta-sistema projeto. As gerências de projetos estão subordinadas a um controle e coordenação do EGP através da metodologia de gestão a ser utilizada e pela gestão integrada de projetos (sistemas 2 e 3). A gestão operacional do porta-fólio ocorre pelo sistema 3 e as áreas demandantes, bem como a alta administração da organização estabelecem comunicação com o EGP, principalmente pelo sistema 4, onde obtém-se as informações do desempenho dos projetos e do porta-fólio corporativo.

O desenvolvimento de uma metodologia própria para a gestão de projetos, adaptada às necessidades da área corporativa de IT dentro do grupo, corresponde, na visão da Cibernética, à outra ação de homeostase que ocorre através de:

- Aumentar o nível de organização interna pela incorporação de práticas específicas, que é produto de aprendizado e criatividade, já que é obtido pela junção do conhecimento já existente, que foi importado do ambiente externo, com as realidades e necessidades do meta-sistema organizacional;

- Reduzir a variedade a ser administrada, uma vez que um padrão de comunicação e controle irá impor restrições aos formatos de linguagem praticados pelas áreas clientes e os recursos de um projeto. 
A estratégia de organização interna do EGP por gerentes de projetos atuando por frentes de negócio (Figura 25) pode também ser caracterizada na Cibernética como uma forma de reduzir-se a variedade a ser administrada por recurso humano. Um gerente de projeto atendendo uma linha de negócio específico pode lidar com um conjunto de variedades reduzidas e sua capacidade de aprendizado também é potencializada.

Sobre o conflito evidenciado pela implementação do EGP e da metodologia de gestão de projetos, na visão de vários autores pesquisados, é consenso que a implementação de EGPs vem acompanhada de uma série de percalços e conflitos (KENDALL; ROLLINS, 2003; CRAWFORD, 2002; DINSMORE; GRAHAM; ENGLUND, 2003) (Seção 3.4.2). Sob o enfoque da Cibernética, o conflito deve-se principalmente à conseqüência de que, a partir da implementação da metodologia de gestão de projetos, as áreas clientes tiveram de aumentar a sua variedade interna para que se pudesse compartilhar do modelo de comunicação estabelecido. Isto é conflitante, principalmente, pelo fato de que as áreas clientes e os recursos de um dado projeto precisavam dos produtos resultantes deste novo modelo de comunicação e estes tiveram que se predispor a investir energia e tempo de seus subsistemas para aprendizado e comunicação protocolada.

Outra evidência importante é a consolidação da nova abordagem em gestão pelo reconhecimento do valor proporcionado às áreas clientes a partir do momento em que estas começam a fazer uso da informação, manifestada pela visibilidade no desempenho de seus projetos (Sistema 4). Esta condição propicia os subsistemas organizacionais, clientes ou interessados em um projeto, a fortalecerem seus regimes de comunicação e controle no processo de implementação de uma estratégia.

Este comportamento, em particular, é sugerido como uma estratégia de sobrevivência para os EGPs (KENDALL; ROLLINS, 2003) ou ainda como uma forma de evoluir os EGPs de iniciativas puramente funcionais para iniciativas em um nível estratégico (TUCKER; AGOPIAN, 2006). 


\subsection{O Modelo de gestão de demandas de projetos}

O grande volume de demandas a serem orçadas em uma pré-concepção de projeto fez com que o EGP da área corporativa de IT repensasse a forma de administrar as solicitações de pré-concepções de projetos das áreas clientes. A solução encontrada foi a de realizar um trabalho preliminar de triagem e classificação das sugestões encaminhadas como projetos potenciais. Um conceito de gestão de demandas foi então implementado com objetivos de promover um filtro, evitando empenho de tempo, tanto da área cliente como da área de IT, em proposições sem a devida prioridade ou fundamento. $O$ processo de gestão de demandas foi estabelecido através de quatro principais fases. A figura 29 ilustra as principais etapas deste processo.

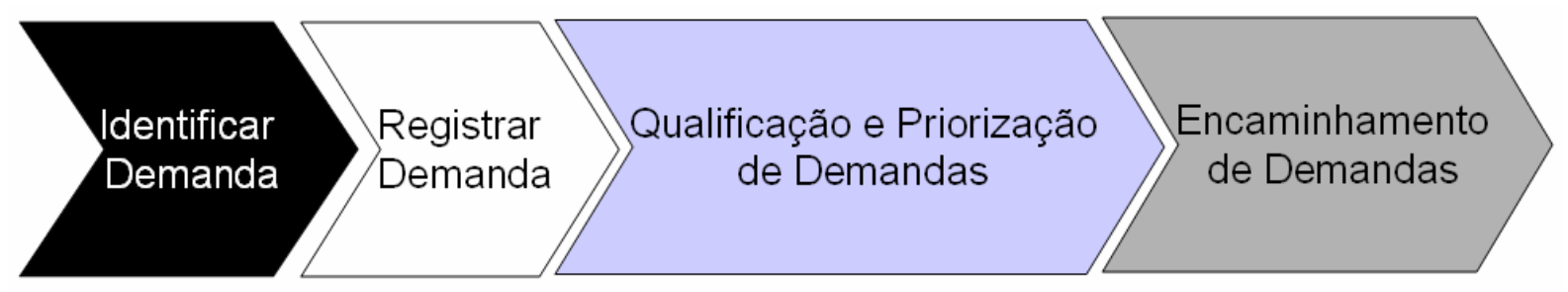

Figura 29 - O Processo de gestão de demandas. As quatro etapas estabelecem um controle e filtro das demandas a serem submetidas ao processo de pré-concepção de projetos.

Para garantir unicidade e consenso nas qualificações e priorizações de demandas, foram desenvolvidas dinâmicas mensais específicas junto às áreas clientes. As dinâmicas tinham como principal papel estabelecer um consenso, na medida em que as decisões eram tomadas pelas as áreas clientes e através de critérios préacordados. As dinâmicas eram orientadas pelo seguinte roteiro:

- Apresentação de novas demandas - Os gestores participantes são incentivados a apresentar, de forma estruturada, suas demandas. As demandas apresentadas são documentadas em uma planilha específica de registro e controle;

- Qualificação de Demandas - Demandas são debatidas e, sob orientação da área de IT, a área estabelece uma qualificação para as demandas, cuja classificação pode variar entre: 
- Descartada - A visão do grupo entende que a proposição não é pertinente, ou seja, não se qualifica como uma real necessidade ou demanda;

- Corretiva - A demanda apresentada pode ser atendida por uma manutenção corretiva em um sistema;

- Evolutiva - A demanda apresentada pode ser tratada por uma pequena evolução pontual em uma funcionalidade de um sistema de informação;

- Projeto - A demanda representa uma necessidade válida na forma de um novo projeto.

- Revisão Sistêmica - Demandas, classificadas como projetos, são avaliadas em conjunto pelo julgamento de suas características, objetivos e dependências. $O$ objetivo é o de identificar ganhos pela unificação de demandas em uma única, ou ainda descartar demandas redundantes ou excludentes;

- Quantificação de Esforços - Demandas, classificadas como projetos, são avaliadas quanto ao seu grau de complexidade e o esforço de implementação, variando entre alto, médio ou baixo. $A$ classificação é obtida por analogia e pela experiência dos participantes, principalmente da área de IT;

- Priorização de Demandas - Demandas, classificadas como projetos, são priorizadas de acordo a pontuação obtida pela média de notas atribuídas pelos próprios gestores da área, com base em critérios ponderados e qualitativos. O peso dos critérios é estabelecido pela própria área com base no entendimento das prioridades estratégicas da empresa. A tabela 6 ilustra o modelo de planilha utilizado;

- Encaminhamento para Pré-Concepção - O grupo define um ponto de corte onde as demandas de maior prioridade serão encaminhadas a um processo de pré-concepção para a formatação de uma proposta a projeto. 


\begin{tabular}{|c|c|c|c|c|c|c|c|c|c|c|c|c|}
\hline \multirow{4}{*}{ N. } & \multirow{4}{*}{$\begin{array}{l}\text { Proposta de Projeto } \\
\text { (DEMANDA) }\end{array}$} & \multicolumn{10}{|c|}{ Critérios de Avaliação } & \multirow{4}{*}{$\begin{array}{l}\text { Total Geral } \\
\text { Pontuação }\end{array}$} \\
\hline & & \multicolumn{2}{|c|}{$\begin{array}{l}\text { Aumento da } \\
\text { Receita }\end{array}$} & \multicolumn{2}{|c|}{$\begin{array}{l}\text { Novo } \\
\text { Produto/Novo } \\
\text { Negócio }\end{array}$} & \multicolumn{2}{|c|}{$\begin{array}{c}\text { Reduçäo de Custo } \\
\text { devido Melhoria do } \\
\text { Processo }\end{array}$} & \multicolumn{2}{|c|}{$\begin{array}{c}\text { Imagem } \\
\text { Institucional }\end{array}$} & \multicolumn{2}{|c|}{$\begin{array}{c}\text { Risco } \\
\text { (Operacionall } \\
\text { Negócio) }\end{array}$} & \\
\hline & & Peso & 3 & Peso & 3 & Peso & 2 & Peso & 1 & Peso & 2 & \\
\hline & & Nota & Total & Nota & Total & Nota & Total & Nota & Total & Nota & Total & \\
\hline \multirow{5}{*}{\multicolumn{2}{|c|}{ 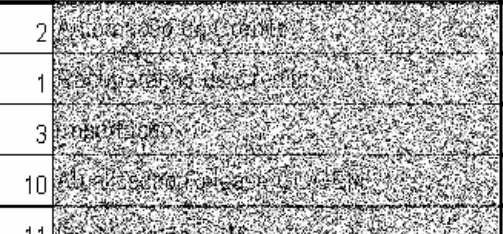 }} & 1 & 3 & 1 & 3 & 3 & 6 & 3 & 3 & 3 & 6 & 21 \\
\hline & & 1 & 3 & 1 & 3 & 3 & 6 & 1 & 1 & 2 & 4 & 17 \\
\hline & & 1 & 3 & 1 & 3 & 1 & 2 & 1 & 1 & 3 & 6 & 15 \\
\hline & & 1 & 3 & 1 & 3 & 1 & 2 & 1 & 1 & 3 & 6 & 15 \\
\hline & & 1 & 3 & 1 & 3 & 1 & 2 & 1 & 1 & 3 & 6 & 15 \\
\hline \multirow{4}{*}{\multicolumn{2}{|c|}{$\begin{array}{l}11 \\
15 \\
18 \\
1\end{array}$}} & 1 & 3 & 1 & 3 & 1 & 2 & 1 & 1 & 3 & 6 & 15 \\
\hline & & 1 & 3 & 1 & 3 & 1 & 2 & 1 & 1 & 3 & 6 & 15 \\
\hline & & 1 & 3 & 1 & 3 & 1 & 2 & 1 & 1 & 2 & 4 & 13 \\
\hline & & 1 & 3 & 1 & 3 & 2 & 4 & 1 & 1 & 1 & 2 & 13 \\
\hline
\end{tabular}

Tabela 6 - Planilha de priorização de demandas. Os nomes das demandas foram propositadamente suprimidos (coluna de Proposta de Projeto). Demandas, classificadas como projetos, são priorizadas de acordo a pontuação obtida pela média de notas atribuídas pelos próprios gestores da área, com base em critérios ponderados e qualitativos. O peso dos critérios é estabelecido pela própria área com base no entendimento das prioridades estratégicas da empresa.

A figura 30 ilustra o processo de redução e filtro de demandas, com base nas dinâmicas estabelecidas junto às áreas clientes.

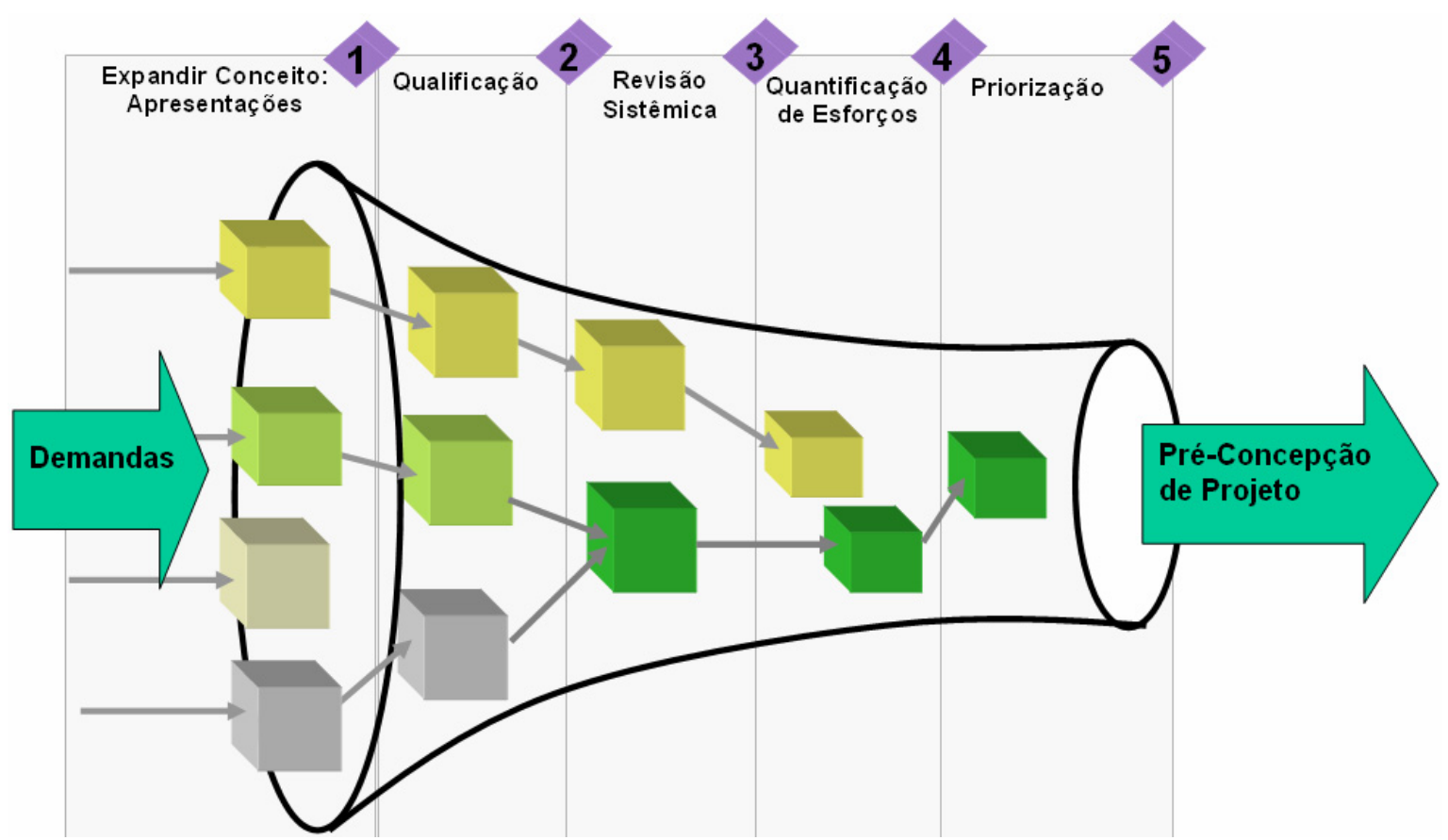

Figura 30 - O filtro de demandas de projetos. As demandas por projetos são submetidas a uma expansão de conceitos que permite o entendimento da idéia ou necessidade. As etapas seguintes estabelecem um filtro e priorização das proposições. Idéias são descartadas ao longo das etapas. As setas convergentes indicam a fusão de idéias. O volume de proposições a serem submetidas à fase de pré-concepção de um projeto sofre uma redução. 
Com a implementação do modelo de gestão de demandas, a metodologia de gestão de projetos da área corporativa de IT do grupo é expandida, incorporando processos similares ao de um modelo de seleção de projetos. A figura 31 ilustra a nova dimensão assumida pela metodologia da área de IT.

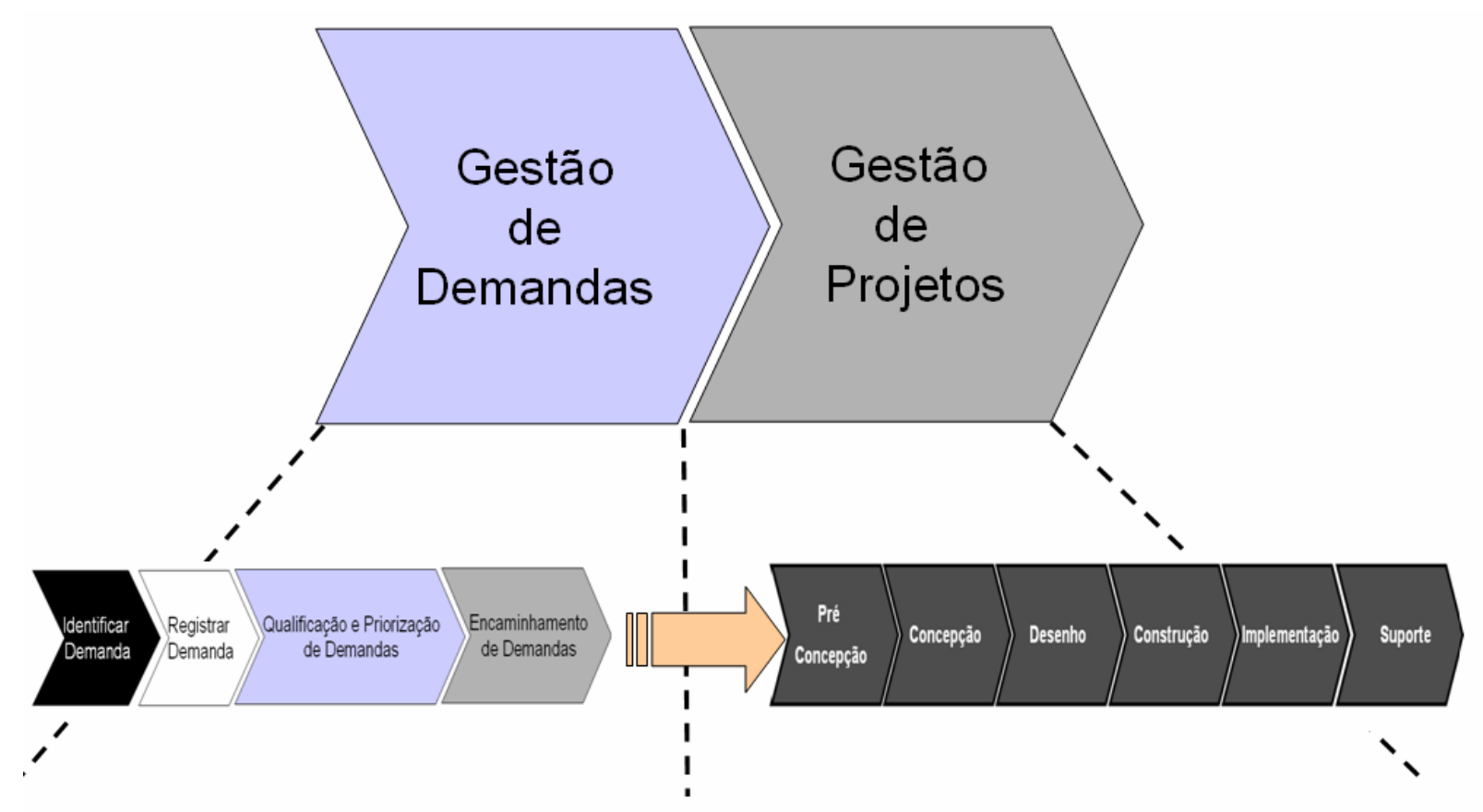

Figura 31 - Expansão da metodologia de gestão de projetos. O processo de gestão de demandas passa a atuar como uma fase preliminar na gestão de projetos, determinando prioridades e quais demandas deverão ser encaminhadas à fase de pré-concepção de um projeto.

Com este novo modelo de gestão de demandas e projetos, além da redução do volume de proposições a serem submetidas ao processo de pré-concepção de projetos, notou-se que o processo de orçamento corporativo passou também a ser beneficiado. Parte do benefício deveu-se a redução de proposições a serem julgadas pelo comitê executivo do grupo, mas um dos principais ganhos foi devido a suas qualidade e orientação estratégica.

Uma das principais conseqüências destes benefícios proporcionados ao processo de orçamento corporativo foi o próprio fortalecimento da metodologia desenvolvida pelo EGP da área de IT do grupo. As áreas que ainda demonstravam resistência no uso do modelo, ou em apoiar os trabalhos que ela demandava, viram-se, de uma outra forma, obrigadas a aderir ao processo, uma vez que a área de planejamento e o comitê executivo passaram a ser mais exigentes nos formatos e conteúdos das 
proposições de projetos submetidos ao orçamento corporativo. A partir de 2005, os modelos de documentações gerados pelos processos de gestão de projetos desenvolvidos pelo EGP da área de IT passaram a ser exigidos como um padrão dentro do grupo para submissão de propostas de projetos que envolviam tecnologia da informação.

\section{$\Rightarrow$ Comentários e interpretação - Seção 5.7}

O grande volume de demandas das áreas clientes a serem orçadas em uma fase de pré-concepção representava um problema administrativo para o EGP da área corporativa de IT. Esta situação, sob a perspectiva da Cibernética, corresponde a um excesso de variedade a ser administrada pelo sistema, neste caso, o EGP. Como resposta a um desbalanceamento entre demanda e capacidade, a estratégia adotada pelo EGP corresponde ao uso dos seguintes princípios da Cibernética:

- Aumento da variedade interna pela inclusão de um processo de triagem e filtro de demandas;

- Redução da variedade a ser administrada, pela limitação do esforço a ser despendido em cada uma das demandas a ser tratadas. Neste caso, não se pode considerar que a variedade a ser administrada tenha sido reduzida pela redução do número de demandas, já que este se manteve inalterado, mas sim pelo filtro introduzido que faz com que o processo de pré-concepção passe a ser menos solicitado.

Sob o enfoque da Cibernética organizacional, observam-se as seguintes conseqüências:

- Aumento de controle, principalmente por estabelecer-se um padrão de contenção que se baseia em um regime de depuração e priorização de demandas; 
- Modelo mais preciso e claro de comunicação nos sistemas que interagem nesta relação (EGP e áreas clientes). A inclusão de um processo estruturado, um padrão comum de documentação e de priorização possibilitou reduzir possiveis conflitos de percepção e ofereceu uma visibilidade maior das contribuições e idéias sendo avaliadas.

O processo de gestão de demandas, incorporado pelo EGP, apresentou ainda uma componente de sinergia, pois existia a possibilidade de se conciliar várias demandas em uma única proposição (etapa de revisão sistêmica das demandas). Portanto, podiam-se satisfazer necessidades distintas, de clientes distintos, em uma ação comum, ou ainda, podia-se evidenciar uma nova oportunidade pela combinação de conceitos distintos.

Em relação à correspondência do processo de gestão de demandas com a disciplina de gestão de porta-fólio de projetos (seção 3.3), cabe aqui realçar que o modelo adotado é limitado, principalmente devido a:

- Ausência de um processo de balanceamento de riscos;

- Ausência de um processo de balanceamento de objetivos estratégicos de médio, longo e curto prazo;

- Maximização de valor no porta-fólio - que exige uma análise de rentabilidade financeira combinada com os riscos aceitáveis entre os vários projetos.

Por outro lado, deve-se considerar que não existem evidências de que o EGP procurava também efetuar um processo de gestão de porta-fólio. $O$ estudo de caso mostra que o objetivo era o de resolver o problema de excesso de pré-concepções a serem encaminhadas. Entretanto, existem características do processo que são compatíveis com a gestão de porta-fólio no que diz respeito à seleção de projetos (seções 3.3.1 e 3.3.2):

- A identificação e registro de demandas podem ser consideradas como uma etapa de exploração ou identificação de idéias; 
- A etapa de qualificação, que ocorre através de uma dinâmica conjunta entre o EGP e as áreas clientes, possui as seguintes similaridades:

- Análise preliminar, que possibilita descartar propostas que não se encontram em um escopo pertinente;

- A revisão sistêmica, que permite enquadrar proposições pelas possíveis relações entre elas, otimizando a configuração de um possivel porta-fólio de projetos;

- Quantificação de esforços, que permite uma análise de viabilidade técnica e financeira em um primeiro grau de estimativa;

- Priorização das demandas, que utiliza um método de pontuação geral baseado em vários critérios e representa uma forma de qualificar o alinhamento das proposições com as estratégias definidas pela organização $e$ estabelecem também prioridades relativas entre as demandas viáveis.

Considerando-se que, no modelo de aprovação de orçamento de investimentos do grupo (seção 5.4.2), não se encontram evidências de boa parte das funcionalidades incorporadas pelo processo de gestão de demandas, pode-se concluir que, de fato, houve uma melhoria na qualidade das propostas a serem submetidas ao processo orçamentário corporativo.

\subsection{Revisão do processo orçamentário}

Em 2006, o planejamento estratégico do grupo foi apoiado por uma consultoria externa que promoveu uma revisão na orientação estratégica dos orçamentos de investimentos para grandes projetos de reformulação de conteúdo com forte ênfase nas mídias eletrônicas e internet. A orientação de estratégias comerciais também sofreu uma revisão, demandando o redesenho de processos e reorganização das áreas de vendas com objetivos de potencializar as receitas do grupo. Os resultados deste planejamento estratégico também recomendavam iniciativas de governanças 
corporativas que impuseram à diretoria financeira necessidades de implementação de processos e políticas estruturadas e padronizadas para todo o grupo.

Com essas novas diretivas estratégicas, a orientação do processo orçamentário imprimiu às áreas e unidades de negócio a necessidade de investimentos de projetos de tecnologia de grande porte financeiro. Áreas de mídia, comercial e financeiro, principalmente, passaram a demandar pela aprovação de projetos de tecnologia de informação, cujos valores, em média, situavam-se na ordem de milhões de reais.

Face à grande exposição financeira e complexidade dos investimentos a serem submetidos neste orçamento, a direção do grupo reestruturou o processo orçamentário para garantir a robustez das propostas a serem submetidas e aprovadas.

O processo orçamentário de investimentos passou a ocorrer em dois momentos de aprovação, alinhando-se à metodologia de gestão de demandas e projetos da área de IT. As principais mudanças incorporadas foram as seguintes:

- A área de planejamento da diretoria financeira passou a participar dos processos de pré-concepção e concepção de projetos previstos na metodologia de gestão de projetos do EGP da área corporativa de IT;

- Antes de serem submetidas ao orçamento corporativo, as propostas de projetos deviam agora ser revisadas internamente pelas áreas de negócio através das dinâmicas de gestão de demandas promovidas pelo EGP da área corporativa de IT;

- Somente as proposições priorizadas e submetidas ao processo de préconcepção de projetos seriam submetidas ao comitê executivo do grupo para a devida priorização e pré-aprovação;

- O comitê executivo passou então a pré-aprovar projetos, ou seja, proposições, que passavam pelo filtro de priorização do orçamento corporativo, deveriam ainda ser submetidas a um segundo momento de detalhamento, correspondente ao processo de concepção previsto na metodologia de gestão de projetos; 
- Após o detalhamento técnico e financeiro das propostas (fase de concepção), para a aprovação final de um projeto, uma nova submissão ao comitê executivo do grupo passou a ser feita para a aprovação final de uma proposta.

Com a implementação das mudanças acima relatadas, o orçamento de investimentos para projetos de tecnologia assumiu a estrutura de processos ilustrados nas figuras 32,33 e 34 .

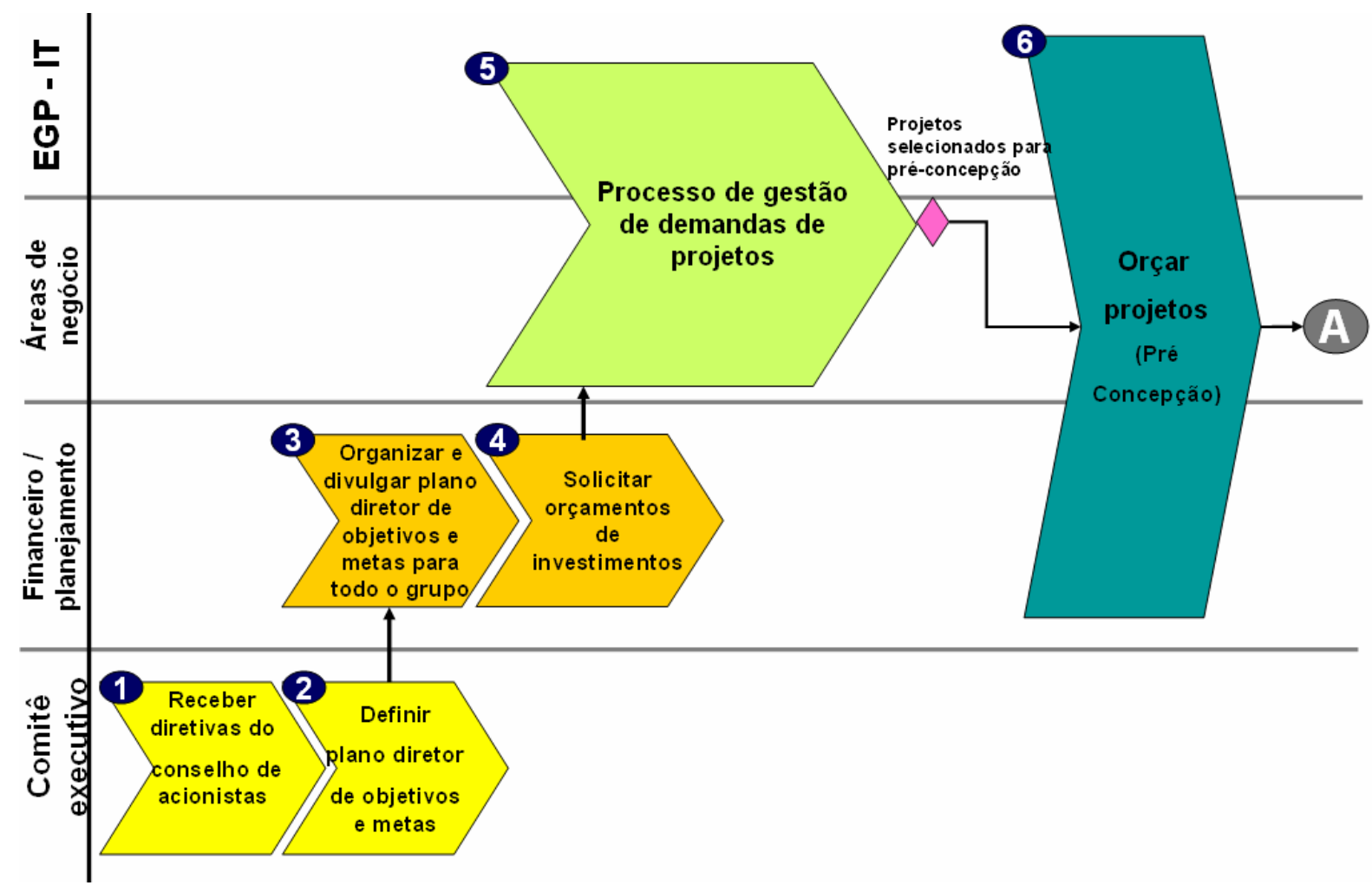

Figura 32 - Fluxo do processo de orçamento de investimentos revisado - Parte I. A coluna da esquerda indica as áreas envolvidas em cada um dos processos indicados pelas setas largas. $A$ numeração dos processos indica a seqüência com a qual eles estabelecem-se. A etapa 5 corresponde à inclusão do processo de gestão de demandas. A etapa 6 corresponde à inclusão da fase de pré-concepção da metodologia de gestão de projetos do EGP. 


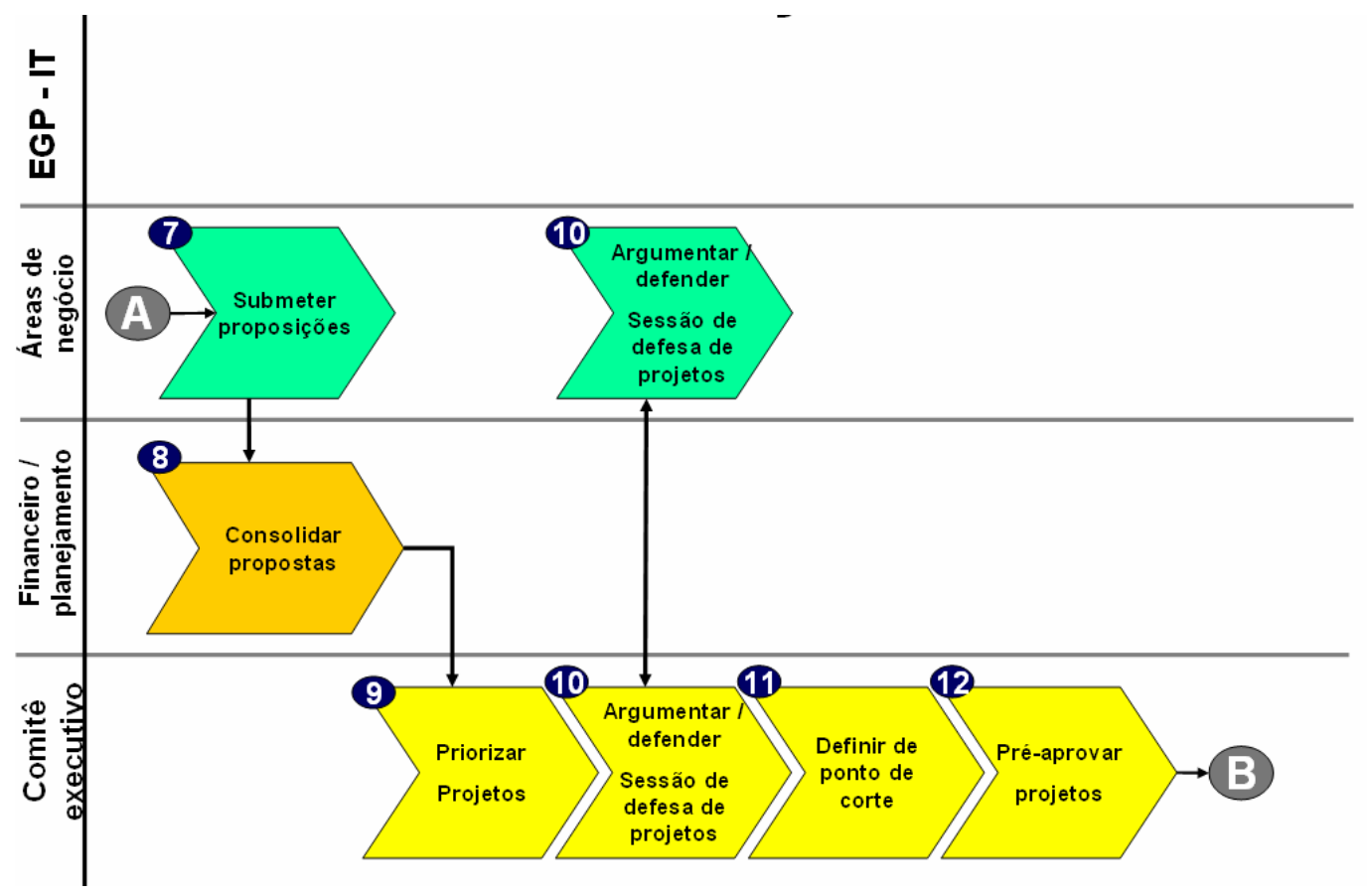

Figura 33 - Fluxo do processo de orçamento de investimentos revisado - Parte II. A coluna da esquerda indica as áreas envolvidas em cada um dos processos indicados pelas setas largas. A numeração dos processos indica a seqüência com a qual eles se estabelecem. Dando seqüência do fluxo anterior (figura 32), após a fase de pré-concepção, o projeto é submetido à priorização pelo comitê executivo. Na etapa 12, ocorre a pré-aprovação dos projetos prioritários.

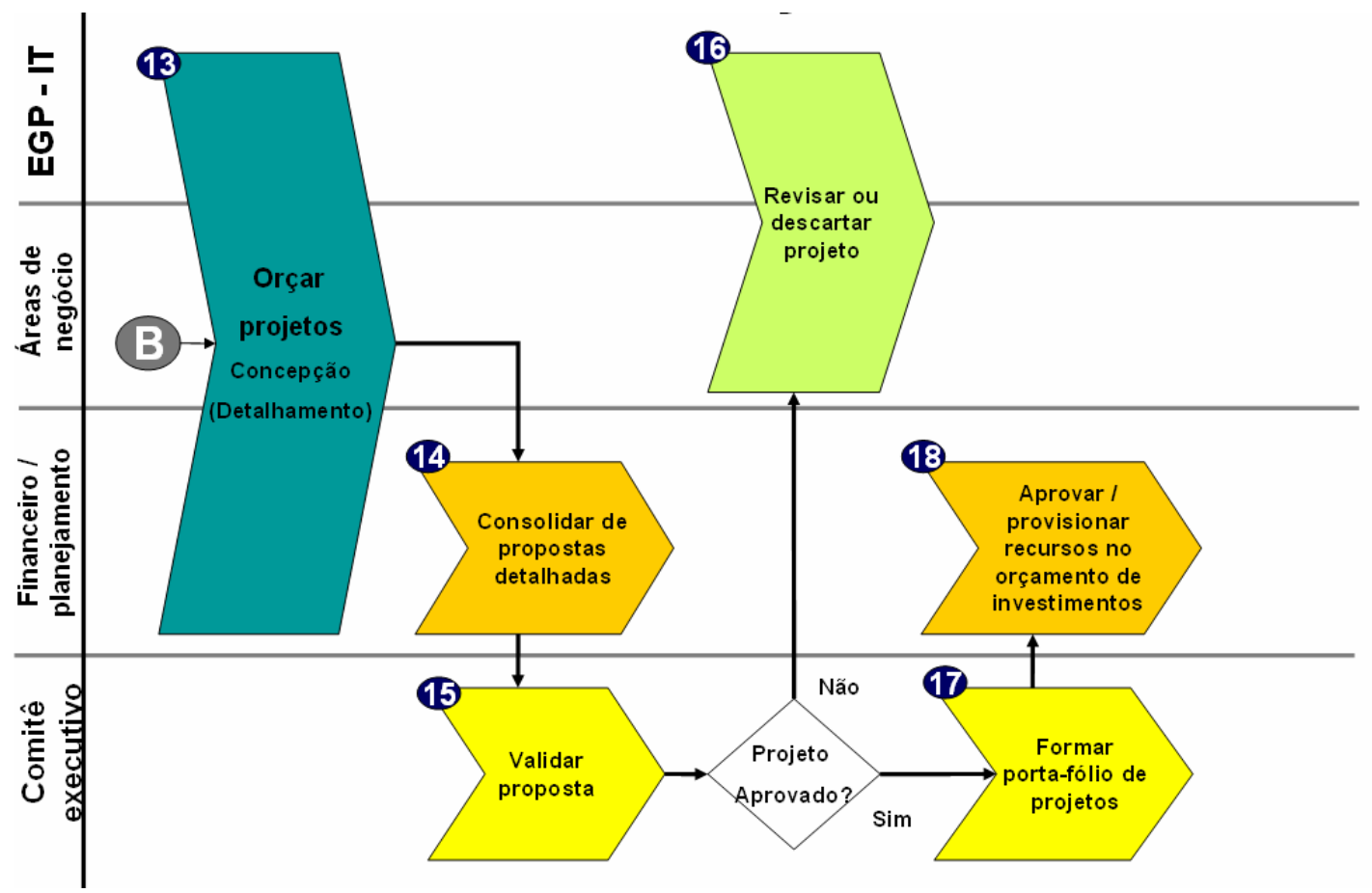

Figura 34 - Fluxo do processo de orçamento de investimentos revisado - Parte III. A coluna da esquerda indica as áreas envolvidas em cada um dos processos indicados pelas setas largas. A numeração dos processos indica a seqüência com a qual eles se estabelecem. Dando seqüência do fluxo anterior (figura 33), após a pré-aprovação de um projeto, este é submetido à fase de concepção da metodologia de gestão de projetos do EGP (etapa 13). A fase de concepção de um projeto corresponde ao detalhamento do escopo, cronograma e orçamento do projeto. Uma vez que o detalhamento ocorra, a proposta é novamente submetida a uma aprovação final pelo comitê executivo. 
Com a implementação do novo modelo de processos do planejamento orçamentário de investimentos, o volume de propostas submetidas ao comitê executivo sofreu uma redução substancial, porém passou a representar um conjunto mais orientado aos objetivos estratégicos do grupo. O modelo, em fases, das priorizações e aprovações de propostas de projetos no orçamento corporativo, bem como as exigências nos modelos de documentação, posteriormente foram também incorporados para os outros tipos de projetos submetidos ao orçamento corporativo.

\section{$\Rightarrow$ Comentários e interpretação - Seção 5.8}

A decisão da alta administração do grupo em utilizar os serviços do EGP no processo de orçamento de investimentos corporativo é uma evidência de que houve um reconhecimento do valor e benefícios que podem ser proporcionados por práticas profissionais de seleção e gestão de projetos.

Esta evidência denota também de que houve uma percepção de que as técnicas envolvidas nos processos de seleção e gestão de projetos deviam ser desempenhadas por estruturas especializadas, que detém o conhecimento e a experiência necessários. Tanto a área de planejamento como as áreas clientes necessitavam de um apoio especializado para que se garantisse um padrão de comportamento e informação compatível com as expectativas da alta direção corporativa.

Sob o enfoque da Cibernética, o uso dos processos, desenvolvidos pelo EGP (gestão de demandas, pré-concepção e concepção de projetos) no modelo de aprovação de investimentos de projetos do orçamento corporativo, corresponde a uma redução de variedade a ser administrada pelo comitê executivo do grupo. As submissões de propostas de projetos ao comitê executivo passaram a ser mais orientadas às estratégias estabelecidas e as informações para a tomada de decisão encontram-se em um padrão comum. O modelo de comunicação e controle foi, portanto, fortalecido. A figura 35 ilustra a reformulação promovida, sob o enfoque do VSM. 


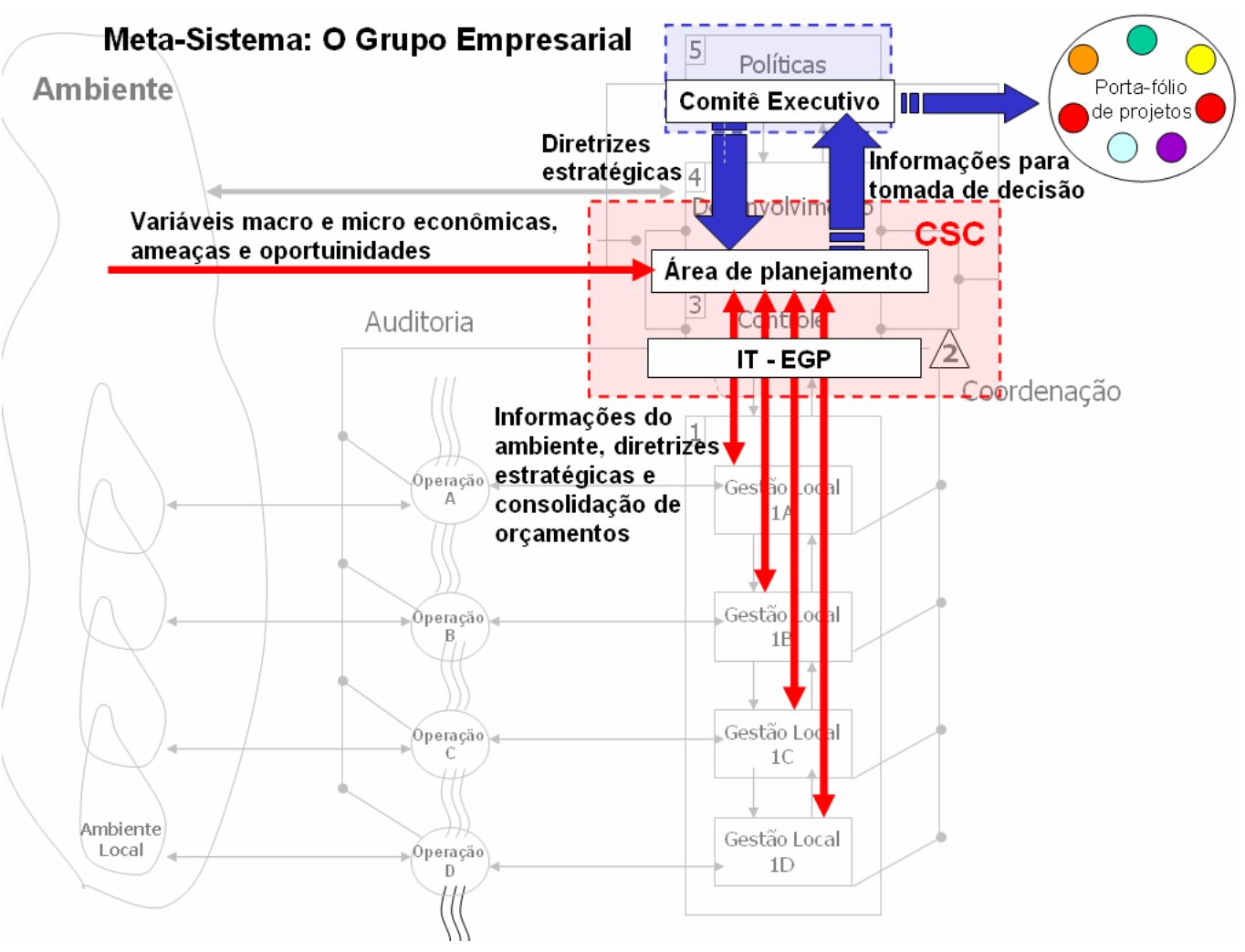

Figura 35 - Visão VSM para o processo de orçamento corporativo do grupo após a revisão, para o componente de investimentos em projetos. As setas em vermelho indicam o fluxo de informações entre ambientes e hierarquias internas nos diversos sistemas (nível 1, 4 e 5). $A$ área em vermelho indica que as atribuições do CSC invadem competências esperadas pelo sistema 4, ou seja, o CSC exibe competências de captação e distribuição de informações do ambiente para a elaboração de um orçamento corporativo. O EGP da área corporativa de IT passa a atuar nos sistemas 2 e 3, junto à área de planejamento e às áreas de negócio e departamentos, como um mecanismo de padronização, apoio e suporte na formulação de propostas de projetos a serem submetidas ao comitê executivo para aprovação. A tomada de decisão na aprovação dos projetos pelo comitê executivo, sistema 5 gera o porta-fólio de projetos corporativos do grupo, indicado na parte superior a esquerda por um círculo.

Uma outra opção de melhoria dos processos de submissão e aprovação de projetos no orçamento corporativo poderia ser a de aumentar a variedade interna de cada uma das subpartes do meta-sistema organizacional, ao mesmo nível de variedade interna presente no EGP, pelo menos no que diz respeito aos processos de gestão de demandas e de projetos nas fases de pré-concepção e concepção.

Esta opção seria possivelmente descartada considerando-se a relação custobenefício, representada pela quantidade de esforço em promover uma homeostase de mesmo porte do EGP, em cada uma das unidades do meta-sistema organizacional. Esta ação também seria equivalente a de retornar a mesma condição do grupo antes da sua reestruturação geral, que buscou eliminar redundâncias e ineficiências. Uma outra contra argumentação desta proposta seria a 
de que os sistemas 2 e 3 teriam também de se especializar para monitorar e controlar as práticas dos sistemas 1 nessas disciplinas, com intuito de garantir que todas as unidades de negócio e departamentos mantenham um padrão comum nesses processos, o que equivale a estabelecer uma condição semelhante à de um EGP, porém, em cada uma das estruturas recursivas do sistema 1.

\subsection{Fechamento}

O estudo de caso proposto encerra-se aqui. Sobre os fatos relatados e evidências apontadas, cabe registrar que a empresa pesquisada ainda mantém-se em um processo de transformação e aprendizado. Muitas das práticas observadas nos períodos anteriores à reestruturação ainda persistem e a transição que o grupo busca ainda implica em um forte trabalho de ajustes em processos e aculturação.

Sobre as questões centrais do estudo de caso, cabe também o comentário de que, embora as transformações ocorridas tenham promovido melhoras substanciais nos desempenhos dos projetos empreendidos pelo grupo, os resultados gerais ainda apontam para a necessidade de um processo constante de amadurecimento e especialização nessas práticas. Por outro lado, as perspectivas para a gestão profissional de projetos dentro do grupo são promissoras. Após a implementação da metodologia de gestão de projetos, promovida pelo EGP da área corporativa de IT, várias áreas de negócio e departamentos, de forma autônoma, também iniciaram programas internos de treinamento na disciplina de gestão de projetos para recursos específicos e estratégicos em seus departamentos. 


\section{Conclusões}

Consideradas as relações e evidências identificadas no estudo de caso, constata-se que o EGP em análise atingiu uma visibilidade corporativa, assumindo um papel importante, ainda que restrito, dentro do modelo decisório do planejamento estratégico e orçamentário do grupo. Este comportamento evidencia uma natural aproximação do papel do EGP como elemento de apoio nas decisões estratégicas do grupo.

Esta evolução natural é argumentada pelo fato de que não há evidências de que, em algum momento, a área de IT corporativa ou o grupo empresarial teve intenções de implementar um EGP com funções orientadas a contextos estratégicos. Os relatos apresentados correspondem ao de uma situação que evoluiu naturalmente devido às necessidades críticas e emergentes decorrentes de um processo de reestruturação corporativa. As demandas inerentes das profundas transformações que o grupo sofreu criaram as condições necessárias para se estabelecer a importância do papel de um EGP dentro do contexto estratégico e estas foram exploradas diante de uma perspectiva de sinergia entre processos.

Em relação à questão da pesquisa, o estudo de caso apresenta um exemplo evolutivo de EGP baseado na percepção gradual de valor proporcionado à organização. Da bibliografia pesquisada, a proposta que melhor representa a realidade evidenciada neste estudo de caso, sugere um modelo de implementação em estágios e através do amadurecimento do EGP em função do seu escopo de atuação.

Destas considerações, conclui-se que a implementação, ou ainda a evolução, de um EGP para contextos estratégicos deve estar alinhada com reais necessidades de uma organização. Desta forma, estabelece-se que a evolução de um EGP para contextos corporativos e estratégicos deve-se valer das seguintes condições e premissas: 
- Existência de necessidades reais e críticas que envolvem a seleção e gestão estratégica de projetos em uma organização;

- Criação de processos, mecanismos e métodos compatíveis com essas necessidades para que se produzam resultados imediatos;

- Os mecanismos e métodos a serem implementados devem também ser compatíveis com o potencial dos recursos envolvidos, o que, de outra forma, provocará uma resistência ainda maior no processo de mudança ou ainda a ausência de percepção do valor proporcionado;

- A presença de condições que permitam os principais executivos interessados e, principalmente, a alta administração corporativa reconhecer as funcionalidades e oportunidade que um EGP oferece em atribuições estratégicas.

O modelo teórico proposto, apresentado na seção 3 , refletiu em grande parte as realidades verificadas no estudo de caso, apresentando um alto grau de previsibilidade, principalmente em relação aos seguintes elementos:

- As dificuldades inerentes da aplicação de processos de planejamento estratégico e orçamentário;

- A forma pela qual projetos são incorporação dentro de um portafólio corporativo;

- As diferentes percepções humanas e riscos a que estes processos decisórios estão sujeitos;

- A necessidade de apoio especializado na construção de uma portafólio de projetos;

- As dificuldades inerentes da implementação de EGPs;

- A validade de estratégias de implementação de EGPs através de modelos evolutivos e de percepção de valor;

As propostas da Cibernética e do VSM também apresentaram uma aderência com a realidade estudada. Muitos dos aspectos, problemas e relações causais apresentados no estudo de caso puderam ser avaliados de forma prática e 
demonstraram-se coerentes com a proposta de que os problemas de desempenho verificados nas organizações podem ser analisados sob a perspectiva da violação de algum princípio da Cibernética.

Uma vantagem constatada pelo uso do VSM foi a sua facilidade de aplicação e sua linguagem qualitativa e gráfica. Através do VSM, foi possível estabelecer análises abrangentes e orientadas ao contexto orgânico e multidisciplinar que o problema em estudo exigiu e permitiu-se também estabelecer uma referência adicional de representação da realidade.

Como extensão da proposta deste trabalho, apresentam-se aqui possibilidades de aprofundamento desta pesquisa, tais como o desenvolvimento de métodos quantitativos para a análise de variedades em ambientes organizacionais e a exploração do modelo de VSM como ferramenta de apoio no desenvolvimento de processos de planejamento estratégicos e orçamentários.

No que diz respeito às práticas relacionadas aos processos de planejamento em ambientes sujeitos a constantes mudanças, como evidenciado no estudo de caso, os modelos convencionais parecem apresentar certa limitação com a realidade vivida pelas organizações, principalmente pelas incertezas a que estas estão sujeitas e a necessidades de desenvolver respostas rápidas. Novas propostas para modelos de planejamentos estratégicos, tais como Generative Relationships, que segmenta ações de estratégia de acordo com cenários de complexidade, parecem sugerir também uma outra perspectiva de estudo para um novo trabalho de pesquisa (LANE; MAXFIELD, 1996).

Como proposta de uma pesquisa aplicada e de disseminação de conhecimentos, esse trabalho é uma contribuição para 0 enriquecimento das práticas organizacionais na gestão estratégica de porta-fólio de projetos. Buscou-se entender o contexto de um problema através da visão de disciplinas diferentes, porém relacionadas dentro de uma cadeia de valores, e relações causais. Conhecimentos e ferramentas foram introduzidos na análise das evidências, permitindo estabelecer uma perspectiva melhor diante da situação evidenciada. A realidade, neste particular contexto, propiciou a validação da aplicabilidade de 
alguns instrumentos disponíveis e evidenciou suas dificuldades de aplicação, permitindo confirmar a validade teórica do modelo proposto sob vários aspectos. 


\section{Referências Bibliográficas}

ANTHONY, R. N. Contabilidade gerencial: introdução à contabilidade. São Paulo: Atlas, 1970.

ASHBY, W. R. An introduction to cybernetics. London: Chapman \& Hall LTD, 1957.

AURÉLIO, B. H. F. Aurélio século XXI. O dicionário da língua portuguesa. Rio de Janeiro: Nova Fronteira, 1999.

BARCAUIU, A B.; QUELHAS, O D. Perfil de escritórios de gerenciamento de projetos em organizações atuantes no Brasil. Revista Pesquisa \& Desenvolvimento Engenharia de Produção, n.02, Jul. 2004.

BECKER, J.; KUGELER, M.; ROSEMANN, M. Process management. A guide for the design of business processes. New York: Springer-Verlag, 2003.

BEER, S. Cibernética e administração industrial. Rio de Janeiro: Zahar, 1969.

. The heart of enterprise. New York: Willey, 1979.

BEINHOCKER, E. D; KAPLAN, S. Tired of strategic planning? The McKinsey Quarterly, n.3, 2002 . Especial Edition

BERTALANFFY, L. V. Teoria geral dos sistemas. Rio de Janeiro: Vozes, 1975.

BRASIL EM FOCO: os 5 desafios dos principais setores da economia. São Paulo: Contra Plano, 2005.

CLELAND, D. I. Project management: strategic design and implementation. New York: McGraw-Hill, 1999.

COPELAND, T. Cutting costs without drawing blood. Harvard Business Review, v.78, n. 5, sept./oct. 2000. 
COOPER, D. R; SCHINDLER, P. S. Métodos de pesquisa em Administração. 7 ed. Porto Alegre: Bookman, 2003

CRAWFORD, J. K. The strategic project office: a guide to improving organizational performance. USA: CRC Press, 2002.

DICKINSON, M. W; THORNTON, A. C.;GRAVES, S. Technology Portfolio Management: Optimizing Interdependent Projects Over Multiple Time Periods. IEEE - Transactions on engineering management, v. 48, n. 4, p. 518-527, 2001.

DINSMORE, P. C. GRAHAM; R. J. ENGLUND; R. L. Creating The Project Office : a manager's guide to leading organizational change. New York: John Wiley \& Sons, 2003.

FLOOD, Robert L. Creative problem solving: total system intervention. New York: John Wiley \& Sons, 2002.

FLYVBJERG, B. Five misunderstandings about case-study research. Qualitative Inquiry. v.12, n.2. Sage Publications, 2006. Disponível em:

< http://online.sagepub.com> .Acesso em :16 Jan.2007.

FRAME, D.; BLOCK, T. The project office. New York: Crisp Publications Inc., 1998.

FORRESTER, J. W. Industrial dynamics. EUA: Pegasus Com., 1999 (a).

. Principles of systems. EUA: Pegasus Com., 1999 (b).

GROSSHANS, W. CHELIMSKY, E. Case Study Evaluations. General Accounting Office. 1990. Disponível em : <www.gao.gov/special.pubs/10_1_9.pdf > Acesso em : 16 fev. 2007.

HAMMER, M.; CHAMPY, J. Reengineering the Corporation: A Manifesto For Business Revolution. New York: Harpercollins, 2001.

HOBSBAWN, E. A era dos extremos: o breve século XX. São Paulo: Companhia das Letras, 1995. 
JACKSON, M. C. System thinking: creative holism for Managers. University of Hull, UK. New York: John Wiley \& Sons, 2003.

KENDALL, G.; ROLLINS, S. Advanced project portfolio management and the PMO: multiplying ROI at warp speed. Boca Raton: J.Ross Publising Inc., 2003.

KERZNER, H. Project management: a system approach to planning, scheduling and controlling. New York: John Wiley \& Sons, 2001 (a).

KERZNER, H. Strategic planning for project management using a project management maturity model. New York: John Wiley \& Sons, 2001 (b).

Advanced project management: Best pratices on implementation. New York: John Wiley \& Sons, 2004.

KOYAMA, H. H; TASSEL, R. V. How to trim Capital Spending by 25 percent. The McKinsey Quarterly, n.3, 1998 .

LANE, D. MAXFIELD, R. Strategy under Complexity: Fostering Generative Relationships. Long Range Planning. Vol. 29, pp.215-231, 1996.

LERE, J. C. Managerial accounting: a planning-operating-control framework. New Jersey: John Wiley \& Sons, 1991.

LAKATOS, E .M.; MARCONI, M. de A. Metodologia científica. São

Paulo: Atlas, 1991.

São Paulo: Atlas, 2003.

Fundamento de metodologia científica.

LORANGE, P.; VANCIL , R. F. Strategic planning systems. USA: Prentice-Hall Inc., 1977.

Corporate planning. USA: Prentice-Hall Inc., 1980.

1982.

Implementation of strategic planning. USA: Prentice-Hall Inc., 
LUNKES, R. J. Manual de orçamento. São Paulo: Atlas, 2003.

MATURANA, H.; VARELA, F. Árvore do conhecimento: as bases biológicas da compreensão humana. São Paulo: Palas athena, 2001.

MEREDITH, J. R; MANTEL, S. J. Project management : a managerial approach. New York: Wiley \& Sons, 2000

MINTZBERG, H.; BRUCE, A. Safári de estratégia: um roteiro pela selva do planejamento estratégico. Porto Alegre: Bookman, 2000.

MINTZBERG, H. ; QUINN, J. B. O processo da estratégia. Porto Alegre: Bookman, 2001.

MOORE, N. Forecasting budgets. New York: Lebhar Friedman Books, 1999.

NEELY, A.; SUTCLIFF, M. R; HEYNS, H. R. Driving value through strategic planning and budgeting. Accenture in Association with Cranfield University, 2001.

PORTER, M. E. Vantagem competitiva: criando e Sustentando um Desempenho Superior. Rio de Janeiro: Campus, 1990.

PRIGOGINE, Ilya, STENGERS, Isabelle. Order out of Chaos. Bantam, 1984.

PRITCHARD, C. L. Risk management: concepts and Guidance. [s.I.]: E S I International, 2001.

PMI, Project Management Institute. PMBOK Guide: Project Management Body of Knowledge. 3. ed. USA: Project Management Institute Inc., 2004.

RAD, P.; LEVIN, G. The advanced project management office: a comprehensive look at function and implementation. Florida: CRC Press, 2002.

RASMUSSEN, N. H. et al. Process Improvement for Effective Budgeting and Financial Reporting. New York: John Wiley \& Sons, 2003 
REBOUÇAS, O. P. D. Planejamento estratégico: conceitos, metodologias e práticas. São Paulo: Atlas 1997.

ROBERTS, N.; et al. Introduction to computer simulation: the system dynamics approach. USA: Lesley College, 1983.

RUSSEL, B. Análise da matéria. Rio de Janeiro: Zahar, 1978.

SANVICENTE, A Z.; SANTOS, C. da C. Orçamento na administração de empresas: planejamento e controle. São Paulo: Atlas, 2000.

SILVA, E. L. da; MENEZES, E. M. Metodologia da pesquisa e elaboração de dissertação. Florianópolis: Universidade Federal de Santa Catarina - UFSC. 2005.

TAVARES, M. C. Gestão estratégica. São Paulo: Atlas, 2000.

SCHEER, A. W. et al. Business process excellence. ARIS in practice. New York: Springer, 2002.

SCHWANINGER, M. Design for viable organizations: the diagnostic power of the viable system model, Switzerland Kybernetes, University of St Gallen, St Gallen v. 35 , n. $7 / 8$, p. 955-966, 2006.

STANDISH GROUP. The chaos report 1994. USA: Disponível em $:<$ http://www.standishgroup.com/sample research/chaos 1994 1.php $>$ Acesso em $: 5$ fev.2007.

TUCKER, C.; AGOPIAN, H. Taking your PMO to the Next Stage. USA: Gartner Institute EXP Premier, mar. 2006.

WIENER, N. Cybernetics or control and communication in the animal and machine. New York: John Wiley, 1948.

YIN, R. K., Estudo de caso: planejamento e métodos. Porto Alegre: Bookman, 2005. 